\title{
Index of Theological Librarianship, 2008-2019
}

Compiled by Barnaby Hughes

\section{INDEX OF TITLES}

“Academic Libraries and Toxic Leadership,” Adams, Richard Manly, Jr., 10:1 (2017), 43-44. https://doi. org/10.31046/tl.v10i1.466

“Achieving Literary Liftoff,” Stewart, David R., 7:2 (2014), iii. https://doi.org/10.31046/tl.v7i2.341

“Action Research for Theological Librarians,” Hamilton, Barry W., 1:1 (2008), 54-59. https://doi.org/10.31046/ tl.v1i1.19

“America's Public Bible,” DeBoer, Jacob A., 11:1 (2018), 53-54. https://doi.org/10.31046/tl.v11i1.505

“Ancient Christian Doctrine,” Parker, T. R., 2:2 (2009), 115-117. https://doi.org/10.31046/tl.v2i2.105

“Apps for Librarians,” Gonzalez, Lisa, 8:2 (2015), 61-62. https://doi.org/10.31046/tl.v8i2.403

"Archives in Libraries: What Librarians and Archivists Need to Know to Work Together," Anderson, Christopher J., 11:2 (2018), 40-41. https://doi.org/10.31046/tl.v11i2.525

“Atlas of Global Christianity,” Friede, Eric, 3:1 (2010), 53-56. https://doi.org/10.31046/tl.v3i1.137

“The Annotated Luther, Volume I: The Roots of Reform,” Cox, David E., 9:2 (2016), 30. https://doi.org/10.31046/ tl.v9i2.450

“The Art of the Bibliographic Essay,” Sheppard, Beth M., 1:1 (2008), 46-48. https://doi.org/10.31046/tl.v1i1.29

“The Assemblies of God: A Bibliographic Essay,” Senapatiratne, Timothy, 4:1 (2011), 91-95. https://doi. org/10.31046/tl.v4i1.171

“Australasian Religion Index (ARI),” Kolb, Daniel, 1:2 (2008), 88. https://doi.org/10.31046/tl.v1i2.54

“Authors on Authoring,” Stewart, David R. and Crown, Ronald W., 5:1 (2012), iii. https://doi.org/10.31046/ tl.v5i1.219

"Awash in a Sea of Archives': Key Research Sources in the United States for the Study of Mission and World Christianity,” Dries, Angelyn, 5:2 (2012), 23-28. https://doi.org/10.31046/tl.v5i2.232

“The Baker Illustrated Bible Dictionary,” Darlack, James Marion, 7:1 (2014), 68-69. https://doi.org/10.31046/ tl.v7i1.319

“Basic Primary Sources in Islamic Religion,” Skreslet, Paula Youngman, 1:1 (2008), 49-53. https://doi. org/10.31046/tl.v1i1.40

“Benedict Biscop: Benedictine, Builder, Bibliophile,” Olley, Lorraine H., 7:1 (2014), 30-37. https://doi. org/10.31046/tl.v7i1.297

"The Best Cataloger is a Frustrated Library User: Cataloging Failure and the Underutilization of Library Resources,” Thompson, John W., 8:2 (2015), 22-27. https://doi.org/10.31046/tl.v8i2.401

“Better Standards for OA Journals,” Ost, Brad, 10:1 (2017), 25-26. https://doi.org/10.31046/tl.v10i1.479 
“The Bible and Handel's Messiah: Some Sources on Their Relation and Use,” Powell, David R., 2:2 (2009), 94-97. https://doi.org/10.31046/tl.v2i2.121

“The Bible in Music: A Dictionary of Songs, Works, and More,” Schroeder, Joy, 9:2 (2016), 35-36. https://doi. org/10.31046/tl.v9i2.428

“Bible Reading Revisited: The Librarian's Guide to Lectio Divina and Formative Styles of Reading," Studzinski, Raymond James, 7:1 (2014), 56-64. https://doi.org/10.31046/tl.v7i1.327

“A Biblical Hebrew Reference Grammar,” Goodwin, Shawn Virgil, 12:1 (2019), 65-67. https://doi.org/10.31046/ tl.v12i1.541

“Bibliographic Essay: Augustine of Hippo,” Fitzgerald, Allan, 8:2 (2015), 46-55. https://doi.org/10.31046/ tl.v8i2.383

“The Blackwell Companion to the Theologians,” Trott, Garrett, 2:2 (2009), 127-129. https://doi.org/10.31046/ tl.v2i2.98

“The Bloomsbury Guide to Pastoral Care,” Ulrich, Jennifer, 8:1 (2015), 89-90. https://doi.org/10.31046/ tl.v8i1.377

“The Book of Revelation and Its Interpreters: Short Studies and an Annotated Bibliography,” Adkins, Martha, 11:2 (2018), 38-39. https://doi.org/10.31046/tl.v11i2.522

“Brill's Encyclopedia of Hinduism,” Weiss, Nicholas, 6:1 (2013), 92-93. https://doi.org/10.31046/tl.v6i1.268

"By the Numbers: Bibliometrics and Altmetrics as Measures of Faculty Impact in the Field of Religion," Sheppard, Beth M., 8:2 (2015), 28-36. https://doi.org/10.31046/tl.v8i2.357

“The Cambridge Dictionary of Christian Theology,” Phillips, Robert, 6:1 (2013), 88-89. https://doi.org/10.31046/ tl.v6i1.252

“The Cambridge Dictionary of Judaism \& Jewish Culture,” Anderson, David, 6:1 (2013), 78-79. https://doi. org/10.31046/tl.v6i1.269

“The Canterbury Dictionary of Hymnology,” McMahon, Melody Layton, 8:1 (2015), 85-86. https://doi. org/10.31046/tl.v8i1.356

“A Case for Slow Reading,” Ostercamp, Matthew J., 7:2 (2014), 9-19. https://doi.org/10.31046/tl.v7i2.338

“The Catholic Church Extension Society Records at Loyola University Chicago,” Young, Kathryn A., 9:2 (2016), 28-29. https://doi.org/10.31046/tl.v9i2.440

“Catholic Pamphlets at the Hesburgh Libraries,” McManus, Jean C., 9:2 (2016), 15-18. https://doi.org/10.31046/ tl.v9i2.441

“The Center for Adventist Research at Andrews University,” Robertson, Terry Dwain, Burt, Merlin D. and Ford, Jim, 8:1 (2015), 24-29. https://doi.org/10.31046/tl.v8i1.368

"Change, Challenge, Opportunity - a Forum on Electronic Journals," Crown, Ronald W. and Stewart, David R., 2:2 (2009), 36. https://doi.org/10.31046/tl.v2i2.122

“Changes Afoot,” Stewart, David R, 8:2 (2015), iii. https://doi.org/10.31046/tl.v8i2.394

“Christian Catechetical Texts,” Mitchell, Michael R., 5:2 (2012), 92-94. https://doi.org/10.31046/tl.v5i2.243

“Christian Librarians and the Ethics of the Library Bill of Rights," Kaihoi, Scott, 8:1 (2015), 42-60. https://doi. org/10.31046/tl.v8i1.353

“Christian Theology: the Classics,” McMullen, Kenneth, 8:2 (2015), 69-70. https://doi.org/10.31046/tl.v8i2.404 
“Christian Traditions in the Contemporary Middle East,” Baker, Matthew, 4:1 (2011), 68-74. https://doi. org/10.31046/tl.v4i1.172

“The Christoph Keller, Jr. Library, General Theological Seminary, New York,” Kadel, Andrew G., 5:1 (2012), 12-15. https://doi.org/10.31046/tl.v5i1.210

“The Church Club of New York Library,” Rider, Jacqueline H., 6:2 (2013), 29-33. https://doi.org/10.31046/ tl.v6i2.296

“Church History: An Introduction to Research Methods and Resources,” Estes, James Andrew, 11:1 (2018), 55-57. https://doi.org/10.31046/tl.v11i1.504

“Church-State Issues in America Today,” Ellis, Teresa Cardin, 1:2 (2008), 83-85. https://doi.org/10.31046/ $\underline{\text { tl.v1i2.53 }}$

“The Cinematic Savior: Jesus Films and Related Literature,” Rainey, Jon, 3:2 (2010), 27-33. https://doi. org/10.31046/tl.v3i2.157

"Citation Analysis and Its Potential In Theological Libraries," Gundry, Jenifer, Senapatiratne, Timothy and Trott, Garrett, 8:2 (2015), 16-21. https://doi.org/10.31046/tl.v8i2.389

“Comparative Review of Three Bible Atlases,” Litwak, Kenneth D., 3:2 (2010), 63-66. https://doi.org/10.31046/ tl.v3i2.165

"A Compendium of Musical Instruments and Instrumental Terminology in the Bible," Campbell, Donna R., 3:2 (2010), 48-50. https://doi.org/10.31046/tl.v3i2.151

“The Comprehensive Theological Bibliography: What is its Future?” Rogers, Anthony D., 5:2 (2012), 48-58. https://doi.org/10.31046/tl.v5i2.203

“Concise American Catholic Encyclopedia,” Hayes, Elyse, 6:1 (2013), 83-85. https://doi.org/10.31046/tl.v6i1.261

“Considerations in Preparing a Biblical Bibliography: Case Study: The Scroll of Esther," Lubetski, Edith and Lubetski, Meir, 3:1 (2010), 31-39. https://doi.org/10.31046/tl.v3i1.129

“The Corban University Library,” Trott, Garrett, 5:1 (2012), 23-25. https://doi.org/10.31046/tl.v5i1.211

"Counting the Costs of Acquisitions: Using Cost-Benefit Analysis in a Seminary and University Library," Getahun, Verena and Keillor, William A., 2:2 (2009), 24-35. https://doi.org/10.31046/tl.v2i2.108

“Crash Course in Library Services to People with Disabilities,” Litwak, Kenneth D., 7:2 (2014), 60-61. https:// doi.org/10.31046/tl.v7i2.328

“Crossroads of War,” Grafton, Karla Fackler, 8:2 (2015), 63-64. https://doi.org/10.31046/tl.v8i2.392

“Cruising the Library: Perversities in the Organization of Knowledge,” Hughes, Barnaby, 10:1 (2017), 46-47. https://doi.org/10.31046/tl.v10i1.470

“The Curious Case of a 'Mayflower Bible',” Coates, Carolyn K., 1:2 (2008), 7-15. https://doi.org/10.31046/ tl.v1i2.59

“Diccionario de Pensadores Cristianos,” Guzman, Alvaro Perez, 5:1 (2012), 81-82. https://doi.org/10.31046/ tl.v5i1.212

“Dictionary of Biblical Criticism and Interpretation,” Woodward, Michael, 2:1 (2009), 113-114. https://doi. org/10.31046/tl.v2i1.74

“Dictionary of Christian Spirituality,” Kokolus, Cait C., 5:2 (2012), 90-91. https://doi.org/10.31046/tl.v5i2.226

“Dictionary of Major Biblical Interpreters,” Powell, David R., 1:1 (2008), 65-67. https://doi.org/10.31046/ $\underline{\text { tl.v1i1.28 }}$ 
“Dictionary of Scripture and Ethics,” Baker, Matthew, 5:2 (2012), 75-77. https://doi.org/10.31046/tl.v5i2.229

"Dictionary of the Bible and Western Culture," Turner, Bob, 7:1 (2014), 77-78. https://doi.org/10.31046/ tl.v7i1.311

“Dictionary of the Old Testament: Prophets,” Evans, Justin J., 7:2 (2014), 58-59. https://doi.org/10.31046/ tl.v7i2.321

“Dictionary of Theologians to 1308,” Bales, John Glenn, 5:2 (2012), 78-79. https://doi.org/10.31046/tl.v5i2.230

“Diktuon: A Good Look at the Nook," Sheppard, Beth M., 4:1 (2011), 3-7.https://doi.org/10.31046/tl.v4i1.173

“Diktuon: Bibliographic Managers,” Keck, Andrew J., 1:2 (2008), 4-5. https://doi.org/10.31046/tl.v1i2.62

“Diktuon: Digital Repositories and Theological Libraries,” Keck, Andrew J., 1:1 (2008), 6-7. https://doi. org/10.31046/tl.v1i1.17

“Diktuon: Drupal - CMS and Beyond,” Darlack, James Marion, 6:2 (2013), 1-3. https://doi.org/10.31046/ tl.v6i2.304

“Diktuon: Finding e-books,” Keck, Andrew J., 3:1 (2010), 1-3. https://doi.org/10.31046/tl.v3i1.143

"Diktuon: Getting Involved With the Digital Humanities in Theology, Biblical Studies, and Religious Studies," Gerber, Kent T. K., 9:1 (2016), 5-10. https://doi.org/10.31046/tl.v9i1.420

“Diktuon: Link Resolvers for Theological Libraries,” Stutzman, Karl, 6:1 (2013), 1-3. https://doi.org/10.31046/ tl.v6i1.257

“Diktuon: Mobile Devices and Libraries,” Keck, Andrew J., 5:1 (2012), 1-3. https://doi.org/10.31046/tl.v5i1.221

"Diktuon: Providing Library Services in the Cloud: New Benefits Realized, New Skills Required," Hartman, Robin R., 7:2 (2014), 6-8. https://doi.org/10.31046/tl.v7i2.348

“Diktuon: Purchasing at the Point of Need: An Acquisitions Pilot Project,” Deeds, Leland, 7:1 (2014), 1-2. https://doi.org/10.31046/tl.v7i1.315

“Diktuon: Tech Training for a New Age,” Bartholomew, Jennifer K., 3:2 (2010), 1-3. https://doi.org/10.31046/ tl.v3i2.160

“Diktuon: The Framework for Information Literacy and Theological Education,” Badke, William, 8:2 (2015), 4-7.https://doi.org/10.31046/tl.v8i2.385

“Diktuon: The Kindle 2 - Risk and Promise," Sheppard, Beth M., 2:2 (2009), 3-8. https://doi.org/10.31046/ $\underline{\text { tl.v2i2.123 }}$

“Diktuon: The Library as Publisher? Is It Possible for a Small Library?” McMahon, Melody Layton, 8:1 (2015), 4-6. https://doi.org/10.31046/tl.v8i1.365

“Diktuon: Virtual Reference,” Keck, Andrew J., 2:1 (2009), 1-2. https://doi.org/10.31046/tl.v2i1.83

“Diktuon: Web-based Statistics Trackers,” Rozear, Hannah, 5:2 (2012), 1-3.https://doi.org/10.31046/tl.v5i2.245

“Doing Theological Research: An Introductory Guide for Survival in Theological Education,” Grafton, Karla Fackler, 4:1 (2011), 101-102. https://doi.org/10.31046/tl.v4i1.179

“Drawing on God: Theology in Graphic Novels," Stanley, Sarah, 2:1 (2009), 83-88. https://doi.org/10.31046/ tl.v2i1.72

“Early Christian Apocrypha: A Bibliographic Essay,” Shepherd, William H., 3:1 (2010), 40-47. https://doi. org/10.31046/tl.v3i1.125

“E-Book Collections,” Gonzalez, Lisa, 3:1 (2010), 57. https://doi.org/10.31046/tl.v3i1.136 
“Editorial,” Stewart, David R., 4:1 (2011), iii. https://doi.org/10.31046/tl.v4i1.196

“Editorial Board Introductions,” Tait, Jennifer Woodruff, 10:1 (2017), iii. https://doi.org/10.31046/tl.v10i1.469

“Editor's Adios,” Stewart, David R., 9:1 (2016), iii. https://doi.org/10.31046/tl.v9i1.416

“Eerdmans Dictionary of Early Judaism,” Grafton, Karla Fackler, 4:1 (2011), 103-104. https://doi.org/10.31046/ tl.v4i1.184

"Effective Leadership in Tough Times: Three Essays," Hook, William J., Myers, Sara J. and Taylor, Sharon A., 2:1 (2009), 20-34. https://doi.org/10.31046/tl.v2i1.92

“E-Journals and the Seminary Library Context; A Response to Jeffrey Garrett,” Sheppard, Beth M., 2:2 (2009), 43-46. https://doi.org/10.31046/tl.v2i2.109

"Encouraging a Positive Outlook: The Benefits of Appreciative Inquiry in a Theological Library," Miller, Rebecca Louise, Denneque, Seblewongel A. and Cunningham, Paige Comstock, 7:1 (2014), 47-55. https:// doi.org/10.31046/tl.v7i1.312

“Encyclopaedia Islamica,” Estelle-Holmer, Suzanne M., 2:2 (2009), 103-104. https://doi.org/10.31046/ tl.v2i2.119

“Encyclopedia of African Religion,” Tarpley, Margaret and Shotts, D’Anna, 2:2 (2009), 124-126. https://doi. org/10.31046/tl.v2i2.102

“Encyclopedia of Buddhism,” Pesch, Christine, 2:1 (2009), 104-105. https://doi.org/10.31046/tl.v2i1.63

“The Encyclopedia of Caribbean Religions,” Dittrich, Nicole C., 7:2 (2014), 56-57. https://doi.org/10.31046/ tl.v7i2.329

"Encyclopedia of Catholic Social Thought, Social Science, and Social Policy,” McIntosh-Doty, Mikail, 1:1 (2008), 68-70. https://doi.org/10.31046/tl.v1i1.20

“The Encyclopedia of Christian Civilization,” Garrett, J. Michael, 5:2 (2012), 82-84. https://doi.org/10.31046/ tl.v5i2.231

“The Encyclopedia of Christian Literature,” Keeney, Donald, 3:2 (2010), 60-62. https://doi.org/10.31046/ tl.v3i2.155

“Encyclopedia of Contemporary Christian Music: Pop, Rock, and Worship,” Schroeder, Joy, 3:1 (2010), 62-63. https://doi.org/10.31046/tl.v3i1.130

“Encyclopedia of Death \& the Human Experience," Ost, Brad, 3:1 (2010), 60-61. https://doi.org/10.31046/ tl.v3i1.132

“Encyclopedia of Demons in World Religions and Cultures,” Day, Donald E., 5:2 (2012), 80-81. https://doi. org/10.31046/tl.v5i2.227

“The Encyclopedia of Eastern Orthodox Christianity,” Stayer, Caren C., 4:1 (2011), 112-113. https://doi. org/10.31046/tl.v4i1.186

“Encyclopedia of English Language Bible Versions,” McMullen, Kenneth, 6:2 (2013), 71-73. https://doi. org/10.31046/tl.v6i2.283

"Encyclopedia of Gender and Society," Klemme, Rebecca, 4:1 (2011), 107-109. https://doi.org/10.31046/ tl.v4i1.169

“Encyclopedia of Hinduism,” Pesch, Christine, 2:1 (2009), 106-107. https://doi.org/10.31046/tl.v2i1.87

“Encyclopedia of Human Rights,” Boyd, Evan E., 3:1 (2010), 51-52. https://doi.org/10.31046/tl.v3i1.141 
“The Encyclopedia of Jews in the Islamic World,” Marcus, Sara, 3:2 (2010), 67-68. https://doi.org/10.31046/ tl.v3i2.166

“Encyclopedia of Love in World Religions,” Jones, Jonathan, 2:1 (2009), 101-103. https://doi.org/10.31046/ tl.v2i1.81

“Encyclopedia of Missions and Missionaries,” Eldevik, Bruce Eugene, 1:2 (2008), 80-82. https://doi. org/10.31046/tl.v1i2.50

“Encyclopedia of New Religious Movements,” Veldheer, Kris, 1:1 (2008), 60-61. https://doi.org/10.31046/ $\underline{\text { tl.v1i1.30 }}$

“Encyclopedia of Pentecostal and Charismatic Christianity,” Tarpley, Margaret, 1:1 (2008), 71-72. https://doi. org/10.31046/tl.v1i1.18

“Encyclopedia of Philosophers on Religion,” Jaeger, John David, 2:1 (2009), 98-100. https://doi.org/10.31046/ tl.v2i1.80

“Encyclopedia of Psychology and Religion,” Hanson, Mark, 3:2 (2010), 57-59. https://doi.org/10.31046/ tl.v3i2.167

“Encyclopedia of Religion and Film,” Gonzalez, Lisa, 6:1 (2013), 80-82. https://doi.org/10.31046/tl.v6i1.263

"Encyclopedia of Religion in America,” Bohanan, Adam S., 4:1 (2011), 98-100. https://doi.org/10.31046/ tl.v4i1.174

“Encyclopedia of Religious and Spiritual Development,” Kokolus, Cait C., 1:2 (2008), 86-87. https://doi. org/10.31046/tl.v1i2.43

“Encyclopedia of Religious Revivals in America," Spomer, Michelle Y., 1:1 (2008), 62-64. https://doi. org/10.31046/tl.v1i1.25

“Encyclopedia of Taoism,” Pesch, Christine, 2:1 (2009), 108-109. https://doi.org/10.31046/tl.v2i1.88

“Encyclopedia of the Bible and Its Reception,” Bergant, Diane and Dunkly, James, 2:2 (2009), 98-102. https:// doi.org/10.31046/tl.v2i2.117

“Encyclopedia of the Historical Jesus,” Hogan, Derek K., 2:1 (2009), 96-97. https://doi.org/10.31046/tl.v2i1.76

“The Encyclopedia of Time: Science, Philosophy, Theology \& Culture,” Steffel, Nick, 3:1 (2010), 67-68. https:// doi.org/10.31046/tl.v3i1.126

“Encyclopedia of Women in Today’s World," Lipton, Saundra, 5:1 (2012), 87-88. https://doi.org/10.31046/ tl.v5i1.218

“Ephrem the Syrian: A Syriac Poet in Armenian Verse,” Mathews, Edward George, 5:1 (2012), 71-76. https:// doi.org/10.31046/tl.v5i1.205

“Esther: A Handbook on the Hebrew Text," Schmersal, David Edward, 9:1 (2016), 45-46. https://doi. org/10.31046/tl.v9i1.417

“An Evaluation of the Accessibility of E-resources from Theological Library Websites,” Ganski, Kate L., 1:1 (2008), 38-45. https://doi.org/10.31046/tl.v1i1.14

"An Evaluation of the Classification Scheme for Adventists and Ellen White," Tan, Felipe E. and Robertson, Terry Dwain, 11:1 (2018), 28-36. https://doi.org/10.31046/tl.v11i1.473

“Expertise and Service: A Call to Action,” Butler, Rebecca, 8:1 (2015), 30-41. https://doi.org/10.31046/tl.v8i1.352 
"Expressions and Encounters: Experiencing the Histories and Theologies of African Christianity in the Collections of Pitts Theology Library: A Critical Evaluation of an Exhibition,” Jones, Arun W., 12:1 (2019), 13-15. https://doi.org/10.31046/tl.v12i1.544

"Expressions and Encounters: Experiencing the Histories and Theologies of African Christianity in the Collections of Pitts Theology Library: A Visiting Scholar's Reflection,” Mombo, Esther, 12:1 (2019), 16-23. https://doi.org/10.31046/tl.v12i1.543

"Expressions and Encounters: Experiencing the Histories and Theologies of African Christianity in the Collections of Pitts Theology Library: An Essay on Curatorial Challenges and Responsibilities,” Aycock, Jennifer L., 12:1 (2019), 5-12. https://doi.org/10.31046/tl.v12i1.542

"Expressions and Encounters: Experiencing the Histories and Theologies of African Christianity in the Collections of Pitts Theology Library: An Introduction to an Exhibition and a Forum,” Adams, Richard Manly, Jr., 12:1 (2019), 3-4. https://doi.org/10.31046/tl.v12i1.546

“Faith Across Time,” Jaeger, John David, 8:1 (2015), 81-82. https://doi.org/10.31046/tl.v8i1.354

"Fake News, Confirmation Bias, the Search for Truth, and the Theology Student," Badke, William, 11:2 (2018), 4-7. https://doi.org/10.31046/tl.v11i2.519

“Father Charles E. Coughlin - the 'Radio Priest' of the 1930s,” Ketchaver, Karen G., 2:2 (2009), 81-88. https:// doi.org/10.31046/tl.v2i2.112

“Featured Web Resource: Theological Commons,” Murray, Gregory P., 9:2 (2016), 1-4. https://doi.org/10.31046/ tl.v9i2.434

"Feminist Biblical Interpretation: A Compendium of Critical Commentary on the Books of the Bible and Related Literature,” Bidlack, Beth, 7:1 (2014), 65-66. https://doi.org/10.31046/tl.v7i1.313

"Find it in the Talmud," Bartholomew, Jennifer K., 8:2 (2015), 56. https://doi.org/10.31046/tl.v8i2.405

“Finding Religion: An Analysis of Theology LibGuides,” Van Dyk, Gerrit, 8:2 (2015), 37-45. https://doi. org/10.31046/tl.v8i2.384

“Finding Time to Write,” Elder, Jane Lenz, 10:1 (2017), 1. https://doi.org/10.31046/tl.v10i1.471

"The Fine Art of Throwing Sheep: How Facebook Can Contribute to Librarianship and Community in Theological Institutions,” Spomer, Michelle Y., 1:1 (2008), 10-21. https://doi.org/10.31046/tl.v1i1.37

“Five Recent Commentaries on Acts,” Wason, Brandon C., 8:1 (2015), 70-76.https://doi.org/10.31046/tl.v8i1.364

“Flip Over Research Instruction: Delivery, Assessment, and Feedback Strategies for ‘Flipped’ Library,” Rosser, Christopher Michael and Willis, Tamie, 9:1 (2016), 22-27. https://doi.org/10.31046/tl.v9i1.413

“Fortress Commentary on the Bible,” McLaurin, III, Dougald W., 8:2 (2015), 67-68. https://doi.org/10.31046/ tl.v8i2.400

“Framing Books and Reading: An Exploration of Sixteenth Century Title Borders,” Graham, M. Patrick, 6:2 (2013), 53-62. https://doi.org/10.31046/tl.v6i2.291

"FRBR and RDA: What They Are and How They May Affect the Future of Libraries,” Croissant, Charles R., 5:2 (2012), 6-22. https://doi.org/10.31046/tl.v5i2.234

“From Intention to Composition: How Seminarians Conceptualize Research," Lincoln, Timothy Dwight and Lincoln, Laura Marie, 4:1 (2011), 41-67. https://doi.org/10.31046/tl.v4i1.178

“From the Co-Editors,” Crown, Ronald W. and Stewart, David R., 3:2 (2010), iii. https://doi.org/10.31046/ $\underline{\text { tl.v3i2.170 }}$ 
“From the Ground Up: Starting a Theological Library from Scratch,” Truman, Gerald, 3:1 (2010), 23-26. https://doi.org/10.31046/tl.v3i1.133

"Funding the Future of African American Religion Archival Collections," Jackson, Andrea, Wiseman, Christine and Ost, Brad, 9:1 (2016), 16-21. https://doi.org/10.31046/tl.v9i1.409

“The Future of the Small Theological Library,” Stephens, Myka Kennedy, 9:1 (2016), 28-32. https://doi. org/10.31046/tl.v9i1.411

“A Gentle Introduction to Topic Modeling Using Python,” Saxton, Micah D., 11:1 (2018), 18-27. https://doi. org/10.31046/tl.v11i1.506

“Global Dictionary of Theology,” Phillips, Robert, 2:2 (2009), 118-120. https://doi.org/10.31046/tl.v2i2.114

“Going a Step Beyond-Websites with More than Just Bibles," Kuykendall, Michael, 3:2 (2010), 22-26. https:// doi.org/10.31046/tl.v3i2.159

“Greater Than the Sum of Its Parts: The Shared Wealth of Scholarly Resources in the Catholic Portal," Maher, Diane, 9:2 (2016), 12-14. https://doi.org/10.31046/tl.v9i2.438

"Growth or Declension: Methodist Historians' Treatment of the Relationship Between the Methodist Episcopal Church and the Culture of the United States,” Teasdale, Mark R., 3:2 (2010), 34-44. https://doi.org/10.31046/ tl.v3i2.163

“A Guide for Writing about Theology and Religion,” Rozear, Hannah, 6:2 (2013), 81-82. https://doi.org/10.31046/ tl.v6i2.272

“Guide to Islamist Movements,” Frost, Ellen, 5:1 (2012), 79-80. https://doi.org/10.31046/tl.v5i1.208

“Handbook for the Study of the Historical Jesus,” Trott, Garrett, 5:1 (2012), 94-95. https://doi.org/10.31046/ tl.v5i1.190

“Handbook of Theological Education in World Christianity,” Iwaskov, Tracy Powell, 4:1 (2011), 110-111. https://doi.org/10.31046/tl.v4i1.185

“A Handbook to Old Testament Exegesis,” Redding, Jonathan David, 11:1 (2018), 51-52. https://doi. org/10.31046/tl.v11i1.495

“Hebrew Language Resources,” Goodwin, Shawn Virgil, 12:1 (2019), 24-39. https://doi.org/10.31046/ tl.v12i1.493

“An Historical Assessment of the Narrative Uses of the Words 'Kabbalah,' 'Cabala,' and 'Qabala/h': Discerning the Differences for Theological Libraries,” Elia, Anthony J., 2:2 (2009), 11-23. https://doi.org/10.31046/ tl.v2i2.111

“Historical Dictionary of Catholicism,” Harty, Kathy, 6:2 (2013), 67-68. https://doi.org/10.31046/tl.v6i2.302

“Historical Dictionary of the Coptic Church,” Bohleke, B., 3:1 (2010), 48-50. https://doi.org/10.31046/tl.v3i1.138

“The Historical Value of Parish Histories,” Rzeznik, Thomas F., 9:2 (2016), 19-22. https://doi.org/10.31046/ tl.v9i2.442

“The History of Western Philosophy of Religion,” Skinner, Michael, 3:2 (2010), 69-71. https://doi.org/10.31046/ tl.v3i2.152

“Homiletics: A Bibliographic Essay,” Stern, Richard C., 6:1 (2013), 69-77. https://doi.org/10.31046/tl.v6i1.262

“How Theological Librarianship Came to Be, and Came to Be Open-Access," Keck, Andrew J., 10:1 (2017), 40. https://doi.org/10.31046/tl.v10i1.482 
“IATG3: Internationales Abkürzungsverzeichnis für Theologie und Grenzgebiete,” Turner, Bob, 9:1 (2016), 61. https://doi.org/10.31046/tl.v9i1.414

“The Illustrated Guide to Islam,” Manzoor, Romana G., 6:2 (2013), 69-70. https://doi.org/10.31046/tl.v6i2.292

“The Impact of Distance Education on Libraries,” Boyd, Kenneth A., 2:1 (2009), 35-44. https://doi.org/10.31046/ tl.v2i1.75

“In a Parallel Universe? A Response to Jeffrey Garrett,” Wenderoth, Christine, 2:2 (2009), 47-50. https://doi. org/10.31046/tl.v2i2.96

“In Praise of the Generalist: Reflecting on the Librarian’s Challenge,” Adams, Richard Manly, Jr., 12:1 (2019), iii. https://doi.org/10.31046/tl.v12i1.545

“In Search of a 'Culture of Writing,” Stewart, David R., 8:1 (2015), iii. https://doi.org/10.31046/tl.v8i1.375

“Incorporating Concepts of Hospitality into Theological Library Assessment,” Gundry, Jenifer, 8:1 (2015), 10-15. https://doi.org/10.31046/tl.v8i1.366

"An Index to English Periodical Literature on the Old Testament and Ancient Near Eastern Studies: Volume IX,” Whitford, Philip, 6:1 (2013), 94-95. https://doi.org/10.31046/tl.v6i1.260

"Influence of the Fathers of the Church on Recent Catholic Conversion Narratives," Kiczek, Steven Allen, 5:1 (2012), 56-66. https://doi.org/10.31046/tl.v5i1.197

"The Information Behavior of a New Generation: Children and Teens in the 21st Century," Roach, Jonathan Chad, 6:2 (2013), 77-78. https://doi.org/10.31046/tl.v6i2.281

“Information Behaviour(s) of Theologians: A Literature Review,” Penner, Katharina, 2:1 (2009), 67-82. https:// doi.org/10.31046/tl.v2i1.79

“The Information: A History, A Theory, A Flood,” Lincoln, Timothy Dwight, 5:1 (2012), 85-86. https://doi. org/10.31046/tl.v5i1.201

“Information Literacy: A Theological Librarian Reflects on Writers and Writing,” Phillips, Robert, 3:1 (2010), 4-5. https://doi.org/10.31046/tl.v3i1.144

"Information Literacy: Adaptability and Authenticity-Using the Next Generation's Powers for Good, Not Evil," Norris, Tiffany Davis, 2:2 (2009), 1-2. https://doi.org/10.31046/tl.v2i2.106

“Information Literacy: More to Learn-and Teach!” Phillips, Robert, 2:1 (2009), 3-4. https://doi.org/10.31046/ tl.v2i1.84

“Information Literacy: Writing Based Research,” Phillips, Robert, 3:2 (2010), 4-5. https://doi.org/10.31046/ tl.v3i2.164

"Information Needs and Behaviours of Theology Students at the International Baptist Theological Seminary," Penner, Katharina, 2:2 (2009), 51-80. https://doi.org/10.31046/tl.v2i2.99

"Information Seeking Behavior of the Ulama in Relation to Preaching and Counseling Roles in Nigeria," Saleh, Adam Gambo and Abu Bakar, Ahmed Bakeri, 6:1 (2013), 29-46. https://doi.org/10.31046/tl.v6i1.177

“Inner-Biblical Allusion,” Lester, G. Brooke, 2:2 (2009), 89-93. https://doi.org/10.31046/tl.v2i2.110

“Innovative Solutions for Building Community in Academic Libraries,” Darling, Kay, 9:2 (2016), 31-32. https:// doi.org/10.31046/tl.v9i2.446

“Inquiry and Research: A Relational Approach in the Classroom,” Smith, Daniel, 12:1 (2019), 63-64. https:// doi.org/10.31046/tl.v12i1.538 
“An Interpretive Lexicon of New Testament Greek,” Fowler, Jason, 10:1 (2017), 45. https://doi.org/10.31046/ tl.v10i1.467

"Introducing the Open Access Digital Theological Library (OADTL): Creating the World's First Entirely Open Access Library in Religious Studies," Phillips, Thomas E., Baker, Drew and Hidalgo, Ann, 11:2 (2018), 1-3. https://doi.org/10.31046/tl.v11i2.520

“Introduction: The Reshaping of Libraries,” Stewart, David R. and Crown, Ronald W., 5:1 (2012), 8. https://doi. org/10.31046/tl.v5i1.220

“An Introductory Dictionary of Theology and Religious Studies,” Willkom, Renee Catherine, 2:1 (2009), 110-112. https://doi.org/10.31046/tl.v2i1.71

"An Invisible Wall: The Relationship Between Congregational and Seminary Libraries in the United States," Eliceiri, Rebecca Klemme, 7:1 (2014), 28-29. https://doi.org/10.31046/tl.v7i1.324

“The James E. Rolfing Memorial Library, Trinity International University,” Hall, Rebekah, 5:1 (2012), 9-11. https://doi.org/10.31046/tl.v5i1.207

“Jesus in History, Legend, Scripture, and Tradition: A World Encyclopedia,” Adkins, Martha, 9:1 (2016), 52-53. https://doi.org/10.31046/tl.v9i1.422

“Jewish Annotated New Testament,” Moll, Kirk A., 5:2 (2012), 95-96. https://doi.org/10.31046/tl.v5i2.244

“The John Richard Allison Library, Regent College,” Williams, Audrey, 5:1 (2012), 26-29. https://doi. org/10.31046/tl.v5i1.217

“The John Stokes and Mary’s Gardens Collection,” Soule, Stephanie L. and Ewalt, Jillian, 9:2 (2016), 23-27. https://doi.org/10.31046/tl.v9i2.439

“Klostersturm and Secularization in Central Europe: What Happened to the Libraries?” Garrett, Jeffrey, 8:1 (2015), 61-69. https://doi.org/10.31046/tl.v8i1.372

“Latinos' Informational Needs in Attaining Accredited Theological Education,” Saxton, Filomena, 7:2 (2014), 20-25. https://doi.org/10.31046/tl.v7i2.342

“Launching an Open Access Journal - Can You Make the Investment?” Gonzalez, Lisa, 10:1 (2017), 41-42. https://doi.org/10.31046/tl.v10i1.483

“Leadership in Theological Education,” Phillips, Robert, 11:2 (2018), 42-43. https://doi.org/10.31046/ tl.v11i2.527

“The Librarian's Guide to the Apostolic Fathers,” Jefford, Clayton N., 5:2 (2012), 59-66. https://doi.org/10.31046/ tl.v5i2.224

“Librarians, Publishers, and Theological Reference Resources: A Way Forward,” McMahon, Melody Layton, 2:1 (2009), 8-19. https://doi.org/10.31046/tl.v2i1.86

“Librarianship as a Spiritual Practice,” Wigner, Dann, 10:1 (2017), 2-4. https://doi.org/10.31046/tl.v10i1.455

"Libraries and Archives: A Comparative Study," Cox, David E., 7:1 (2014), 67. https://doi.org/10.31046/ tl.v7i1.310

“Libraries and Universal Design,” Spina, Carli, 10:1 (2017), 5-7. https://doi.org/10.31046/tl.v10i1.464

“Library of the Associated Mennonite Biblical Seminary,” Saner, Eileen K., 5:1 (2012), 19-22. https://doi. org/10.31046/tl.v5i1.213

“The Library of the Universidad Bíblica Latinoamericana: 75th Anniversary in the Midst of Changes," Guzman, Alvaro Perez, 4:1 (2011), 8-15. https://doi.org/10.31046/tl.v4i1.195 
"Library Research Instruction for Doctor of Ministry Students: Outcomes of Instruction Provided by a Theological Librarian and by a Program Faculty Member,” Kamilos, Charles D. and Birch, Rodney, 7:1 (2014), 38-46. https://doi.org/10.31046/tl.v7i1.325

“Library Services for the North Carolina Field Minister Program," Fowler, Jason, 11:2 (2018), 13. https://doi. org/10.31046/tl.v11i2.524

“The Literature of Ecclesiology: A Ten Year Retrospective,” Guyette, Fred, 4:1 (2011), 75-90. https://doi. org/10.31046/tl.v4i1.146

“The Marjory Stanway Collection of African Language Materials at Trinity School for Ministry," Hanson, Susanah J., 6:1 (2013), 16-20. https://doi.org/10.31046/tl.v6i1.259

“Marketing Today's Academic Library: A Bold New Approach to Communicating with Students," Ganski, Kate L., 2:2 (2009), 105-106. https://doi.org/10.31046/tl.v2i2.100

“Masterplots II: Christian Literature,” Benda, Chris, 1:2 (2008), 77-79. https://doi.org/10.31046/tl.v1i2.49

“Melton's Encyclopedia of American Religions," Hamilton, Barry W., 2:2 (2009), 107-108. https://doi. org/10.31046/tl.v2i2.103

“Mentoring in the Library: Building for the Future,” McMahon, Melody Layton, 5:1 (2012), 89-90. https://doi. org/10.31046/tl.v5i1.182

"Ministers on the Lecture Circuit: Education, Entertainment and Religion in Early 20th Century America," Gonzalez, Lisa, 7:1 (2014), 21-27. https://doi.org/10.31046/tl.v7i1.314

“More Technology for the Rest of Us,” Tait, Jennifer Woodruff, 3:2 (2010), 72-73. https://doi.org/10.31046/ tl.v3i2.168

“Muhammad in History, Thought, and Culture," Cox, David E., 8:2 (2015), 59-60. https://doi.org/10.31046/ tl.v8i2.376

“Murphy Memorial Library, Baptist Bible College and Seminary,” Michael, Joshua, 5:1 (2012), 16-18. https:// doi.org/10.31046/tl.v5i1.209

“Narratives of Reading in Luke-Acts,” Weaver, John B., 1:1 (2008), 22-37. https://doi.org/10.31046/tl.v1i1.27

“New Catholic Encyclopedia Supplement 2009,” Hayes, Elyse, 2:2 (2009), 109-111. https://doi.org/10.31046/ tl.v2i2.115

“A New Era for Theological Librarianship," Bennett, Miranda H., Daught, Gary F. and Estelle-Holmer, Suzanne M., 9:2 (2016), iii. https://doi.org/10.31046/tl.v9i2.448

“New International Dictionary of New Testament Theology and Exegesis,” Darlack, James Marion, 9:1 (2016), 50-51. https://doi.org/10.31046/tl.v9i1.421

“The New Interpreter's Handbook of Preaching,” Shepherd, William H., 2:2 (2009), 121-123. https://doi. org/10.31046/tl.v2i2.104

“New Routes to Library Success,” Morris, Angela G., 9:2 (2016), 33-34. https://doi.org/10.31046/tl.v9i2.445

“The New Westminster Dictionary of Church History,” Leahy, Elizabeth A., 3:1 (2010), 58-59. https://doi. org/10.31046/tl.v3i1.139

“A Note to Prospective Authors,” Editorial Team, 1:1 (2008), 5. https://doi.org/10.31046/tl.v1i1.39

“Novice Contributor Tells All,” Stewart, David R., 7:1 (2014), iii. https://doi.org/10.31046/tl.v7i1.330

"Now You See It: How the Brain Science of Attention Will Transform the Way We Live, Work, and Learn," Wenderoth, Christine, 5:2 (2012), 99-100. https://doi.org/10.31046/tl.v5i2.236 
““Oh, the Editor's Life is the Life for Me ...,” Stewart, David R., 6:1 (2013), iii. https://doi.org/10.31046/tl.v6i1.267 “Open Access,” Stewart, David R., 7:1 (2014), 72-74. https://doi.org/10.31046/tl.v7i1.323

“Open Access and Authors’ Rights Management: A Possibility for Theology?” Smith, Kevin L., 2:1 (2009), 45-56. https://doi.org/10.31046/tl.v2i1.73

"The Open Access Availability of Articles from Highly Ranked Religious Studies Journals: A Study of Ten Journals,” Avery, Joshua M., 11:1 (2018), 12-17. https://doi.org/10.31046/tl.v11i1.465

“Open Access Liturgical Resources for Judaism,” Nosek, Jason D., 6:2 (2013), 63-66. https://doi.org/10.31046/ tl.v6i2.265

“An Open Access Source for the Study of Religion and the Law: The Proceedings of the Old Bailey: London's Central Criminal Court 1674-1913," Guyette, Fred, 1:2 (2008), 28-37. https://doi.org/10.31046/tl.v1i2.60

“Our Second Issue,” Crown, Ronald W. and Stewart, David R., 1:2 (2008), 3. https://doi.org/10.31046/tl.v1i2.65

“Oxford Biblical Studies Online,” Gonzalez, Lisa, 2:1 (2009), 91-93. https://doi.org/10.31046/tl.v2i1.85

“The Oxford Companion to the Book,” Eldevik, Bruce Eugene, 3:2 (2010), 54-56. https://doi.org/10.31046/ tl.v3i2.156

“Oxford Dictionary of the Bible and Archaeology,” Swanson, Dennis M., 7:1 (2014), 75-76. https://doi. org/10.31046/tl.v7i1.322

“The Oxford Dictionary of the Jewish Religion,” Bartholomew, Jennifer K., 5:1 (2012), 77-78. https://doi. org/10.31046/tl.v5i1.214

“The Oxford Encyclopaedia of South Asian Christianity,” Phillips, Robert, 6:2 (2013), 74-76. https://doi. org/10.31046/tl.v6i2.301

“Oxford Encyclopedia of Biblical Interpretation,” Senapatiratne, Timothy, 7:2 (2014), 62-63. https://doi. org/10.31046/tl.v7i2.333

“The Oxford Encyclopedia of the Books of the Bible," Hanson, Susanah J., 5:2 (2012), 85-87. https://doi. org/10.31046/tl.v5i2.222

“The Oxford Handbook of African American Theology,” Murrain, Shanee Yvette, 10:1 (2017), 48-49. https:// doi.org/10.31046/tl.v10i1.468

“The Oxford Handbook of Christianity and Economics,” Lillard, Justin Matthew, 8:1 (2015), 83-84. https:// doi.org/10.31046/tl.v8i1.355

“The Oxford Handbook of Early Christian Studies,” Mukunthan, Cumaraswamy Michael, 2:2 (2009), 112-114. https://doi.org/10.31046/tl.v2i2.94

“The Oxford Handbook of Interdisciplinarity,” Harper, Wakefield, 5:2 (2012), 88-89. https://doi.org/10.31046/ tl.v5i2.228

“The Oxford Handbook of Religious Conversion,” Bales, John Glenn, 8:1 (2015), 77-78. https://doi.org/10.31046/ tl.v8i1.371

“Participatory Cultures and Implications for Theological Education,” Crowley, Eileen D., 6:1 (2013), 60-68. https://doi.org/10.31046/tl.v6i1.251

“The Pastor's Library: An Annotated Bibliography of Biblical and Theological Resources for Ministry," Rosenbeck, Craig, 11:2 (2018), 44. https://doi.org/10.31046/tl.v11i2.528

"Peer-reviewing the Publishers: the Scholarly Open Access Appeals Board, 2013-2016," Hughes, Barnaby, 10:1 (2017), 27-32. https://doi.org/10.31046/tl.v10i1.480 
“The Perennial Question and a Radical Response: The Student Bibliographer Program in the Vanderbilt Divinity Library," Crawford, Eileen, 6:2 (2013), 9-19. https://doi.org/10.31046/tl.v6i2.273

“The Personal Librarian: Enhancing the Student Experience,” Gucker, Jacob W., 8:2 (2015), 65-66. https:// doi.org/10.31046/tl.v8i2.402

“Personenlexikon zum Zweiten Vatikanischen Konzil,” Cox, David E., 8:1 (2015), 79-80. https://doi. org/10.31046/tl.v8i1.339

“'Playing Well With Others': New Opportunities for Library Consortia,” Wiser, James, 5:2 (2012), 43-47. https:// doi.org/10.31046/tl.v5i2.237

“Pocket Dictionary of Theological Terms,” Bartholomew, Jennifer K., 9:1 (2016), 49. https://doi.org/10.31046/ tl.v9i1.419

“Pope Francis' Strong Thought,” Lemna, Keith Edward, 7:2 (2014), 45-53. https://doi.org/10.31046/tl.v7i2.343

“Practical Tips for Facilitating Research,” Stevens, Kerrie, 9:2 (2016), 37. https://doi.org/10.31046/tl.v9i2.443

“The Praeger Handbook of Religion and Education in the United States,” Shaffett, John E., 3:1 (2010), 64-66. https://doi.org/10.31046/tl.v3i1.127

“The Princeton Encyclopedia of Islamic Political Thought,” Skreslet, Paula Youngman, 6:2 (2013), 83-85. https://doi.org/10.31046/tl.v6i2.290

“Prison Theological Librarianship,” Griffin, Jeff, 11:2 (2018), 14. https://doi.org/10.31046/tl.v11i2.508

“Profiles: Doralyn Joanne Hickey, 1929-1987: An Appreciation,” Loyd, Roger, 6:1 (2013), 4-6. https://doi. org/10.31046/tl.v6i1.256

“Profiles: A Giant in the Land: H. Lucille Hager, 1924-2004,” Eberts, Susan, 8:1 (2015), 1-3. https://doi. org/10.31046/tl.v8i1.373

“Profiles: A Pilgrim's Progress: Decherd Turner, 1922-2002,” Hotchkiss, Valeri, 7:1 (2014), 3-5. https://doi. org/10.31046/tl.v7i1.326

"Profiles: Aspiring Vision and Attention to Detail: Kenneth Sperber Gapp (1905-1966),” Dearborn, Virginia E. and Henke, Kenneth W., 8:2 (2015), 1-3. https://doi.org/10.31046/tl.v8i2.396

“Profiles: Bibliographer Extraordinaire: Peter De Klerk, 1927-1997,” Schemper, Lugene L., 7:2 (2014), 1-3. https://doi.org/10.31046/tl.v7i2.345

“Profiles: Father Oliver Kapsner, OSB (1902-1991) - A Life in Libraries,” Heintzelman, Matthew, 5:1 (2012), 4-6. https://doi.org/10.31046/tl.v5i1.216

“Profiles: Fr. Simeon Daly, OSB,” McMahon, Melody Layton, 9:1 (2016), 1-4. https://doi.org/10.31046/tl.v9i1.415

“Profiles: John Albert Bollier, 1927-2010,” Estelle-Holmer, Suzanne M., 6:2 (2013), 4-6. https://doi. org/10.31046/tl.v6i2.305

“Profiles: Quiet Person, Powerfully Loud Influence: Norris Magnuson (1932-2006),” Oslund, Sandra, 9:2 (2016), 9-11. https://doi.org/10.31046/tl.v9i2.433

"Providing Library Services to Prisoners: Calvin College and Calvin Seminary at Handlon Correctional Facility," Malone, David Brian, 11:2 (2018), 15. https://doi.org/10.31046/tl.v11i2.514

"Pushing the Margins: Women of Color and Intersectionality in LIS,” Murphy, Ondrea M., 12:1 (2019), 61-62. https://doi.org/10.31046/tl.v12i1.540

“The Quality Library: A Guide to Staff-Driven Improvement, Better Efficiency, and Happier Customers," Burnam, Paul D., 2:1 (2009), 89-90. https://doi.org/10.31046/tl.v2i1.70 
“'Quinquennial' - Reflecting on TL’s Fifth Anniversary,” Stewart, David R., 6:2 (2013), iii. https://doi. org/10.31046/tl.v6i2.306

“The Qumran Visualization Project: Prospects for Digital Humanities in Theological Libraries,” Murphy, Benjamin P., 5:2 (2012), 29-38. https://doi.org/10.31046/tl.v5i2.240

“'Raising an Ebenezer': Archives as a Religious Means of Remembering,” Malone, David Brian, 8:1 (2015), 16-19. https://doi.org/10.31046/tl.v8i1.369

“RDA Toolkit,” Kettner, Megan, 4:1 (2011), 105-106. https://doi.org/10.31046/tl.v4i1.175

"Reading and E-reading for Academic Work: Patterns and Preferences in Theological Studies and Religion," Lincoln, Timothy Dwight, 6:2 (2013), 34-52. https://doi.org/10.31046/tl.v6i2.293

“Reading for Faith and Learning,” Sheppard, Beth M., 10:1 (2017), 50-52. https://doi.org/10.31046/tl.v10i1.476

“Recent Research in Religion: A Citation Analysis,” Adkins, Martha, 11:2 (2018), 16-26. https://doi.org/10.31046/ tl.v11i2.507

"Reference Guide to Christian Missionary Societies in China and Christianity in China: A Scholar's Guide to Resources in the Libraries and Archives of the United States,” DeLong, Linwood, 3:2 (2010), 51-53. https:// doi.org/10.31046/tl.v3i2.145

“Religion and American Cultures: Tradition, Diversity, and Popular Expression, 2nd Edition,” Ost, Brad, 9:1 (2016), 47-48. https://doi.org/10.31046/tl.v9i1.418

“Religion and the Law in America," Guyette, Fred, 2:1 (2009), 94-95. https://doi.org/10.31046/tl.v2i1.55

“The Religion and Theology Student Writer's Manual and Reader’s Guide,” Shrauner, Ryan Douglas, 12:1 (2019), 68-70. https://doi.org/10.31046/tl.v12i1.539

"Religion and Violence: An Encyclopedia of Faith and Conflict from Antiquity to the Present," McMullen, Kenneth, 5:1 (2012), 91-93. https://doi.org/10.31046/tl.v5i1.199

“Religion Past and Present,” Wright, Logan S., 1:2 (2008), 93-95. https://doi.org/10.31046/tl.v1i2.46

"Religious Celebrations: An Encyclopedia of Holidays, Festivals, Solemn Observances, and Spiritual Commemorations,” Morris, Angela G., 5:2 (2012), 97-98. https://doi.org/10.31046/tl.v5i2.239

“Religious Leadership: A Reference Handbook,” Burr, Trisha A., 7:2 (2014), 54-55. https://doi.org/10.31046/ tl.v7i2.337

“Religious Nationalism: A Reference Handbook,” Dekker, Jennifer, 7:1 (2014), 70-71. https://doi.org/10.31046/ tl.v7i1.320

“Religious Studies Journals in Beall's List,” Daught, Gary, 10:1 (2017), 33-39. https://doi.org/10.31046/ tl.v10i1.481

"A Remarkable Collection of Rare Scriptures in a Small University Library Setting," Ellis, Teresa Cardin, 6:2 (2013), 20-28. https://doi.org/10.31046/tl.v6i2.298

"Research and Writing in the Seminary: Practical Strategies and Tools," Berryhill, Carisse, 8:2 (2015), 57-58. https://doi.org/10.31046/tl.v8i2.406

"Resources for the Study of the Classical World in the New Testament Era," Sheppard, Beth M., 5:2 (2012), 67-74. https://doi.org/10.31046/tl.v5i2.223

“The Rise and Fall of Union Classification,” Butler, Rebecca, 6:1 (2013), 21-28. https://doi.org/10.31046/ tl.v6i1.254

“Ronald Knox: A Bibliographic Essay,” Chappel, James, 1:2 (2008), 49-53. https://doi.org/10.31046/tl.v1i2.44 
“Routledge Companion to Christian History,” Schottler, Sophie, 1:2 (2008), 89-90. https://doi.org/10.31046/ tl.v1i2.52

“The Routledge Companion to Religion and Popular Culture,” Wason, Brandon C., 9:2 (2016), 42-43. https:// doi.org/10.31046/tl.v9i2.432

“The Routledge Companion to the Practice of Christian Theology,” Trott, Garrett, 9:2 (2016), 40-41. https:// doi.org/10.31046/tl.v9i2.449

“The Routledge Handbook of Research Methods in the Study of Religion,” Roland, Daniel R., 6:2 (2013), 79-80. https://doi.org/10.31046/tl.v6i2.285

"Running with Perseverance: The Theological Library's Challenge of Keeping Pace With Changing Students," Falciani-White, Nancy K., 1:2 (2008), 16-27. https://doi.org/10.31046/tl.v1i2.61

“The SBL Handbook of Style, 2nd Edition,” Rosauer, Greg, 9:1 (2016), 54-56. https://doi.org/10.31046/tl.v9i1.424

“Scholarly Communications: A History from Content as King to Content as Kingmaker," Boyd, Evan E., 9:1 (2016), 57-58. https://doi.org/10.31046/tl.v9i1.425

"Search Committees: A Comprehensive Guide to Successful Faculty, Staff, and Administrative Searches," Roach, Jonathan Chad, 8:1 (2015), 87-88. https://doi.org/10.31046/tl.v8i1.351

"Secret Sisters: Women Religious under European Communism Collection at the Catholic Theological Union," Tinerella, Vincent P., 3:2 (2010), 8-15. https://doi.org/10.31046/tl.v3i2.154

“Seeing the Salzburgers in their Books,” Reeves, Timothy Scott, 11:1 (2018), 1-11. https://doi.org/10.31046/ tl.v11i1.474

“Six Segments on Military Ministry,” Knapp, Kathryn, 3:1 (2010), 27-30. https://doi.org/10.31046/tl.v3i1.134

"Small Change, Big Impact: Assessment and Creative Re-purposing of Underutilized Space at the BU Theology Library," Smith, Sean, 12:1 (2019), 1-2. https://doi.org/10.31046/tl.v12i1.536

“Special Forum: Best Professional Development Experiences, Spring 2014,” Pakala, James C., Butler, Rebecca, Darlack, James Marion, Day, Donald E., Kroll, Anna Lois, Amodeo, Anthony, Engelson, Leslie A. and Stewart, David R., 7:2 (2014), 26-30. https://doi.org/10.31046/tl.v7i2.344

“Staff Development on a Shoestring,” Shaffett, John E., 6:1 (2013), 90-91. https://doi.org/10.31046/tl.v6i1.241 “STEP Bible,” Miller, Elizabeth Young, 11:1 (2018), 58-59. https://doi.org/10.31046/tl.v11i1.503

“Student Theological Research as an Invitation,” Badke, William, 5:1 (2012), 30-42. https://doi.org/10.31046/ tl.v5i1.200

“Supporting Digital Humanities for Knowledge Acquisition in Modern Libraries,” Taylor, Sharon A., 9:2 (2016), 38-39. https://doi.org/10.31046/tl.v9i2.429

“T\&T Clark Companion to Methodism,” Keck, Andrew J., 5:1 (2012), 83-84. https://doi.org/10.31046/tl.v5i1.215

“T\&T Clark Handbook to Social Identity in the New Testament,” Gonzalez, Lisa, 9:1 (2016), 59-60. https://doi. org/10.31046/tl.v9i1.426

“Tales of an Editor,” Tait, Jennifer Woodruff, 9:1 (2016), 33-37. https://doi.org/10.31046/tl.v9i1.412

“Teaching the History of the Bible as Book," Eldevik, Bruce Eugene, 9:1 (2016), 38-44. https://doi.org/10.31046/ tl.v9i1.427

“Telling the Library’s Story: A Personal Reflection,” Stuehrenberg, Paul, 5:2 (2012), 39-42. https://doi. org/10.31046/tl.v5i2.235 
“Theologians and Philosophers Using Social Media: Advice, Tips, and Testimonials,” Tait, Jennifer Woodruff, 11:1 (2018), 60. https://doi.org/10.31046/tl.v11i1.510

“Theological Librarian vs. Machine: Taking on the Amazon Alexa Show (with Some Reflections on the Future of the Profession)," Sheppard, Beth M., 10:1 (2017), 8-23. https://doi.org/10.31046/tl.v10i1.475

“The Theological Librarian’s Role in Fundraising,” Kemmis, Barbara, 2:1 (2009), 57-66. https://doi. org/10.31046/tl.v2i1.77

“Theological Librarians and Collection Management: Collaborative Policy Development,” Mayer, Robert J., 11:2 (2018), 8-11. https://doi.org/10.31046/tl.v11i2.530

“Theological Librarianship at 10: A Long Look Back, a Long Look Forward,” Tait, Jennifer Woodruff, 11:2 (2018), iii-viii. https://doi.org/10.31046/tl.v11i2.526

“Theological Librarianship from a Distance,” Detar, Melody Diehl, 8:2 (2015), 11-15. https://doi.org/10.31046/ tl.v8i2.390

“Theological Librarianship Talks Open Access,” Tait, Jennifer Woodruff, 10:1 (2017), 24. https://doi.org/10.31046/ tl.v10i1.477

“Theological Librarianship: An Unapologetic Apology,” McMahon, Melody Layton, 3:1 (2010), 7-14. https:// doi.org/10.31046/tl.v3i1.131

“Theological Libraries and 'The Next Christendom:' Connecting North American Theological Education to Uses of the Book in the Global South,” Weaver, John B., 1:2 (2008), 38-48. https://doi.org/10.31046/tl.v1i2.45

“Theological Libraries and International Collaboration in Southeast Asia,” Stuehrenberg, Paul, 4:1 (2011), 32-40. https://doi.org/10.31046/tl.v4i1.194

“Theological Libraries and Scholarly Publishing in Religion and Theology,” Keck, Andrew J., 11:2 (2018), 27-37. https://doi.org/10.31046/tl.v11i2.518

“Theological Libraries in Prison: A Special Forum,” Tait, Jennifer Woodruff, 11:2 (2018), 12. https://doi. org/10.31046/tl.v11i2.532

“There is Nothing New Under the Sun?: 'New Librarianship' and the Theological Library,” Osinski, Keegan, 8:1 (2015), 20-23. https://doi.org/10.31046/tl.v8i1.370

“Thomas Merton: American Monk, Artist and Social Critic,” Belcastro, David Joseph, 7:2 (2014), 31-44. https:// doi.org/10.31046/tl.v7i2.334

“Three Catholic Libraries in London,” McMahon, Melody Layton, 4:1 (2011), 22-31. https://doi.org/10.31046/ tl.v4i1.192

“Toward a Greater Discourse: Issues in Religious Archives,” Presutti, Robert, 3:1 (2010), 15-22. https://doi. org/10.31046/tl.v3i1.135

“Towards an Online Searchable Bibliographic Database for Ismā '̄ilī Studies,” Jiwa, Nawazali Alibhai, 11:1 (2018), 37-50. https://doi.org/10.31046/tl.v11i1.478

“Twenty Years of Theological Markup Languages: A Retro- and Prospective,” MoChridhe, Race J., 12:1 (2019), 40-49. https://doi.org/10.31046/tl.v12i1.523

“Two Years On,” Crown, Ronald W. and Stewart, David R., 2:2 (2009), iii. https://doi.org/10.31046/tl.v2i2.124

"Uganda Christian University: A Center of Excellence in the Heart of Africa-An Overview of the UCU Library," Kiyaga, John, 4:1 (2011), 16-21. https://doi.org/10.31046/tl.v4i1.193 
“Understanding Mormonism: Foundational Sources on its Culture, History, and Theology,” Van Dyk, Gerrit, 12:1 (2019), 50-60. https://doi.org/10.31046/tl.v12i1.531

“An Unknown Exegete: Uncovering the Biblical Scholarship of Elizabeth Barrett Browning,” Elia, Anthony J., 7:1 (2014), 8-20. https://doi.org/10.31046/tl.v7i1.266

"Using Sermon Text Archives to Investigate the Construction of Social Values: A Proposal for a Collaborative Research Agenda in Social Epistemology,” Roland, Daniel R., 5:1 (2012), 43-55. https://doi.org/10.31046/ tl.v5i1.188

“Using Technology for Ministry: Trends, Principles and Applications,” Vergel, Alfredo, 3:2 (2010), 16-21. https://doi.org/10.31046/tl.v3i2.128

“Voices of Early Christianity: Documents from the Origins of Christianity,” Webb, Lee, 7:1 (2014), 79-80. https://doi.org/10.31046/tl.v7i1.318

“'We Desire Everything Illustrating the History of Methodism That We Can Procure': Examining the Methodist Collections at Drew University,” Anderson, Christopher J., 6:1 (2013), 9-15. https://doi.org/10.31046/ tl.v6i1.264

“Web Review: Global Anabaptist Mennonite Encyclopedia Online (GAMEO),” Ulrich, Jennifer, 7:1 (2014), 6-7. https://doi.org/10.31046/tl.v7i1.317

“Web Review: Hymnary.org - Comprehensive Index of Hymns and Hymnals,” Mayo, David, 5:2 (2012), 4-5. https://doi.org/10.31046/tl.v5i2.233

“Web Review: Online Resources for the Study of Chinese Religion and Philosophy,” Adkins, Martha, 9:2 (2016), 5-8. https://doi.org/10.31046/tl.v9i2.435

“Web Review: Perseus Digital Library,” Darlack, James Marion, 9:1 (2016), 11-15. https://doi.org/10.31046/ tl.v9i1.423

“Web Review: Spirituality, Medicine and Health Bibliography,” Skypeck, James R., 6:2 (2013), 7-8. https:// doi.org/10.31046/tl.v6i2.271

"Web Review: The Association of Religion Data Archives," Murrain, Shanee Yvette, 7:2 (2014), 4-5. https:// doi.org/10.31046/tl.v7i2.336

“Web Review: The Jonathan Edwards Center at Yale University,” Miller, Rebecca Louise, 5:1 (2012), 7. https:// doi.org/10.31046/tl.v5i1.206

“Web Review: The Pew Forum on Religion \& Public Life,” Burr, Trisha A., 6:1 (2013), 7-8. https://doi. org/10.31046/tl.v6i1.258

"Web Review: Working Virtually on the Text and Manuscripts Behind the Document: Doing New Testament Textual Criticism on the Web," Phillips, Thomas E. and Bilby, Mark Glen, 8:1 (2015), 7-9. https://doi. org/10.31046/tl.v8i1.374

"Web Review: Working Virtually on the Texts and Manuscripts Behind the Document, II: Doing Jewish Bible/ Old Testament Textual Criticism on the Web,” Phillips, Thomas E. and Baker, Drew, 8:2 (2015), 8-10. https:// doi.org/10.31046/tl.v8i2.393

“Web Reviews: Counterbalance,” Limpitlaw, Amy, 2:1 (2009), 5-7. https://doi.org/10.31046/tl.v2i1.82

“Web Reviews: ETANA,” Estelle-Holmer, Suzanne M., 1:2 (2008), 6. https://doi.org/10.31046/tl.v1i2.64

“Web Reviews: Monachos.net-Orthodoxy Through Patristic, Monastic, and Liturgical Study, Schwab, Juliet Crawford, 3:2 (2010), 6-7. https://doi.org/10.31046/tl.v3i2.158 
“Web Reviews: Online Critical Pseudepigrapha and Online Medieval Sources Bibliography,” Vorp, Donald M., 1:1 (2008), 8-9. https://doi.org/10.31046/tl.v1i1.21

“Web Reviews: Religious Institute-Denominational Statements,” Durham, Erica, 4:1 (2011), 1-2. https://doi. org/10.31046/tl.v4i1.191

"Web Reviews: The Gifford Lectures-Over 100 Years of Renowned Lectures on Natural Theology," Limpitlaw, Amy, 3:1 (2010), 6. https://doi.org/10.31046/tl.v3i1.140

“Web Reviews: Theological Perspectives of the Reformation,” Limpitlaw, Amy, 2:2 (2009), 9-10. https://doi. org/10.31046/tl.v2i2.116

"Welcome to Our Third Issue of Theological Librarianship," Crown, Ronald W., 2:1 (2009), iii. https://doi. org/10.31046/tl.v2i1.93

“Welcome to Theological Librarianship,” Norlin, Dennis A., 1:1 (2008), 3. https://doi.org/10.31046/tl.v1i1.36

“We're All Librarians Now?” Tait, Jennifer Woodruff, 11:1 (2018), iii. https://doi.org/10.31046/tl.v11i1.509

“Westminster Dictionary of Theologians," Siedlecki, Armin, 1:2 (2008), 91-92. https://doi.org/10.31046/ tl.v1i2.42

“Why Theological Librarianship?” Crown, Ronald W. and Stewart, David R., 1:1 (2008), 4. https://doi.org/10.31046/ tl.v1i1.35

“Why Write for Peer Review?” Crown, Ronald W., 5:2 (2012), iii. https://doi.org/10.31046/tl.v5i2.246

“Why Write?” Stewart, David R. and Crown, Ronald W., 3:1 (2010), iii. https://doi.org/10.31046/tl.v3i1.147

“William Penn's Experiment in Religious Freedom: Resources Documenting the Colonial Religious Experience at the State Library of Pennsylvania,” Snavely, Iren Light, 1:2 (2008), 60-76. https://doi.org/10.31046/ tl.v1i2.48

"Wood, Flour, Journal: How the Electronic Turn Has Affected the Way Journals are Found, Used, and Read," Garrett, Jeffrey, 2:2 (2009), 37-42. https://doi.org/10.31046/tl.v2i2.97

"Words of Wisdom: A Philosophical Dictionary for the Perennial Tradition,” Ost, Brad, 6:1 (2013), 86-87. https://doi.org/10.31046/tl.v6i1.248

“The Work of Evelyn Fox Keller as a Resource for Study in Science and Religion,” Kordesh, Kathleen, 1:2 (2008), 54-59. https://doi.org/10.31046/tl.v1i2.56

"World Biographical Information System (WBIS Online) and the Biographical Archive of Christianity (BAChr)," Anderson, Christopher J., 4:1 (2011), 96-97. https://doi.org/10.31046/tl.v4i1.176

“Worship in the Early Church,” Brennan, Christopher, 3:2 (2010), 45-47. https://doi.org/10.31046/tl.v3i2.148

"Wrestling Long into the Night: Sources on the Mainline Protestant Denominations' Debate about Homosexuality," Burnam, Paul D., 6:1 (2013), 47-59. https://doi.org/10.31046/tl.v6i1.249

“Zen Garden and No Zen Garden: A Bibliographic Essay,” Masuchika, Glenn Norio, 5:1 (2012), 67-70. https:// doi.org/10.31046/tl.v5i1.204

\section{INDEX OF AUTHORS}

Abu Bakar, Ahmed Bakeri and Saleh, Adam Gambo, "Information Seeking Behavior of the Ulama in Relation to Preaching and Counseling Roles in Nigeria,” 6:1 (2013), 29-46. https://doi.org/10.31046/tl.v6i1.177

Adams, Richard Manly, Jr., “Academic Libraries and Toxic Leadership,” 10:1 (2017), 43-44. https://doi. org/10.31046/tl.v10i1.466 
---, “In Praise of the Generalist: Reflecting on the Librarian’s Challenge,” 12:1 (2019), iii. https://doi. org/10.31046/tl.v12i1.545

-- , "Expressions and Encounters: Experiencing the Histories and Theologies of African Christianity in the Collections of Pitts Theology Library: An Introduction to an Exhibition and a Forum,” 12:1 (2019), 3-4. https://doi.org/10.31046/tl.v12i1.546

Adkins, Martha, “Jesus in History, Legend, Scripture, and Tradition: A World Encyclopedia,” 9:1 (2016), 52-53. https://doi.org/10.31046/tl.v9i1.422

-—-, “Web Review: Online Resources for the Study of Chinese Religion and Philosophy,” 9:2 (2016), 5-8. https://doi.org/10.31046/tl.v9i2.435

---, “Recent Research in Religion: A Citation Analysis,” 11:2 (2018), 16-26. https://doi.org/10.31046/ $\underline{\text { tl.v11i2.507 }}$

-—-, “The Book of Revelation and Its Interpreters: Short Studies and an Annotated Bibliography,” 11:2 (2018), 38-39. https://doi.org/10.31046/tl.v11i2.522

Amodeo, Anthony, Butler, Rebecca, Pakala, James C., Darlack, James Marion, Day, Donald E., Kroll, Anna Lois, Engelson, Leslie A., Stewart, David R., “Special Forum: Best Professional Development Experiences, Spring 2014,” 7:2 (2014), 26-30. https://doi.org/10.31046/tl.v7i2.344

Anderson, Christopher J., "World Biographical Information System (WBIS Online) and the Biographical Archive of Christianity (BAChr),” 4:1 (2011), 96-97. https://doi.org/10.31046/tl.v4i1.176

- - , “We Desire Everything Illustrating the History of Methodism That We Can Procure': Examining the Methodist Collections at Drew University,” 6:1 (2013), 9-15. https://doi.org/10.31046/tl.v6i1.264

Anderson, Christopher J., "Archives in Libraries: What Librarians and Archivists Need to Know to Work Together," 11:2 (2018), 40-41. https://doi.org/10.31046/tl.v11i2.525

Anderson, David, “The Cambridge Dictionary of Judaism \& Jewish Culture,” 6:1 (2013), 78-79. https://doi. org/10.31046/tl.v6i1.269

Avery, Joshua M., “The Open Access Availability of Articles from Highly Ranked Religious Studies Journals: A Study of Ten Journals,” 11:1 (2018), 12-17. https://doi.org/10.31046/tl.v11i1.465

Aycock, Jennifer L., "Expressions and Encounters: Experiencing the Histories and Theologies of African Christianity in the Collections of Pitts Theology Library: An Essay on Curatorial Challenges and Responsibilities,” 12:1 (2019), 5-12. https://doi.org/10.31046/tl.v12i1.542

Badke, William, “Student Theological Research as an Invitation,” 5:1 (2012), 30-42. https://doi.org/10.31046/ tl.v5i1.200

-_-, “Diktuon: The Framework for Information Literacy and Theological Education,” 8:2 (2015), 4-7. https:// doi.org/10.31046/tl.v8i2.385

---, "Fake News, Confirmation Bias, the Search for Truth, and the Theology Student,” 11:2 (2018), 4-7. https://doi.org/10.31046/tl.v11i2.519

Baker, Drew and Phillips, Thomas E., "Web Review: Working Virtually on the Texts and Manuscripts Behind the Document, II: Doing Jewish Bible/Old Testament Textual Criticism on the Web,” 8:2 (2015), 8-10. https://doi.org/10.31046/tl.v8i2.393

-—-, Phillips, Thomas E. and Hidalgo, Ann, "Introducing the Open Access Digital Theological Library (OADTL): Creating the World's First Entirely Open Access Library in Religious Studies,” 11:2 (2018), 1-3. https://doi. org/10.31046/tl.v11i2.520 
Baker, Matthew, “Christian Traditions in the Contemporary Middle East,” 4:1 (2011), 68-74. https://doi. org/10.31046/tl.v4i1.172

-_-, "Dictionary of Scripture and Ethics," 5:2 (2012), 75-77. https://doi.org/10.31046/tl.v5i2.229

Bales, John Glenn, “Dictionary of Theologians to 1308,” 5:2 (2012), 78-79. https://doi.org/10.31046/tl.v5i2.230

-_-, “The Oxford Handbook of Religious Conversion,” 8:1 (2015), 77-78. https://doi.org/10.31046/tl.v8i1.371

Bartholomew, Jennifer K., “Diktuon: Tech Training for a New Age,” 3:2 (2010), 1-3. https://doi.org/10.31046/ tl.v3i2.160

-_-, “The Oxford Dictionary of the Jewish Religion,” 5:1 (2012), 77-78. https://doi.org/10.31046/tl.v5i1.214

-—-, “Find it in the Talmud,” 8:2 (2015), 56. https://doi.org/10.31046/tl.v8i2.405

-_-, “Pocket Dictionary of Theological Terms,” 9:1 (2016), 49. https://doi.org/10.31046/tl.v9i1.419

Belcastro, David Joseph, “Thomas Merton: American Monk, Artist and Social Critic,” 7:2 (2014), 31-44. https:// doi.org/10.31046/tl.v7i2.334

Benda, Chris, “Masterplots II: Christian Literature,” 1:2 (2008), 77-79. https://doi.org/10.31046/tl.v1i2.49

Bennett, Miranda H., Daught, Gary F., and Estelle-Holmer, Suzanne M., “A New Era for Theological Librarianship,” 9:2 (2016), iii. https://doi.org/10.31046/tl.v9i2.448

Bergant, Diane and Dunkly, James, “Encyclopedia of the Bible and Its Reception,” 2:2 (2009), 98-102. https:// doi.org/10.31046/tl.v2i2.117

Berryhill, Carisse, “Research and Writing in the Seminary: Practical Strategies and Tools," 8:2 (2015), 57-58. https://doi.org/10.31046/tl.v8i2.406

Bidlack, Beth, "Feminist Biblical Interpretation: A Compendium of Critical Commentary on the Books of the Bible and Related Literature,” 7:1 (2014), 65-66. https://doi.org/10.31046/tl.v7i1.313

Bilby, Mark Glen and Phillips, Thomas E., “Web Review: Working Virtually on the Text and Manuscripts Behind the Document: Doing New Testament Textual Criticism on the Web,” 8:1 (2015), 7-9. https://doi. org/10.31046/tl.v8i1.374

Birch, Rodney and Kamilos, Charles D., "Library Research Instruction for Doctor of Ministry Students: Outcomes of Instruction Provided by a Theological Librarian and by a Program Faculty Member," 7:1 (2014), 38-46. https://doi.org/10.31046/tl.v7i1.325

Bohanan, Adam S., “Encyclopedia of Religion in America,” 4:1 (2011), 98-100. https://doi.org/10.31046/ tl.v4i1.174

Bohleke, B., "Historical Dictionary of the Coptic Church,” 3:1 (2010), 48-50. https://doi.org/10.31046/tl.v3i1.138

Boyd, Evan E., “Encyclopedia of Human Rights,” 3:1 (2010), 51-52. https://doi.org/10.31046/tl.v3i1.141

--_, "Scholarly Communications: A History from Content as King to Content as Kingmaker," 9:1 (2016), 57-58. https://doi.org/10.31046/tl.v9i1.425

Boyd, Kenneth A., “The Impact of Distance Education on Libraries,” 2:1 (2009), 35-44. https://doi.org/10.31046/ tl.v2i1.75

Brennan, Christopher, “Worship in the Early Church,” 3:2 (2010), 45-47. https://doi.org/10.31046/tl.v3i2.148

Burnam, Paul D., “The Quality Library: A Guide to Staff-Driven Improvement, Better Efficiency, and Happier Customers,” 2:1 (2009), 89-90. https://doi.org/10.31046/tl.v2i1.70 
-- - "Wrestling Long into the Night: Sources on the Mainline Protestant Denominations' Debate about Homosexuality,” 6:1 (2013), 47-59. https://doi.org/10.31046/tl.v6i1.249

Burr, Trisha A., “Web Review: The Pew Forum on Religion \& Public Life,” 6:1 (2013), 7-8. https://doi. org/10.31046/tl.v6i1.258

-_-, “Religious Leadership: A Reference Handbook,” 7:2 (2014), 54-55. https://doi.org/10.31046/tl.v7i2.337

Burt, Merlin D., Robertson, Terry Dwain and Ford, Jim, “The Center for Adventist Research at Andrews University,” 8:1 (2015), 24-29. https://doi.org/10.31046/tl.v8i1.368

Butler, Rebecca, “The Rise and Fall of Union Classification,” 6:1 (2013), 21-28. https://doi.org/10.31046/ tl.v6i1.254

---, “Expertise and Service: A Call to Action,” 8:1 (2015), 30-41. https://doi.org/10.31046/tl.v8i1.352

-_-, Pakala, James C., Darlack, James Marion, Day, Donald E., Kroll, Anna Lois, Amodeo, Anthony, Engelson, Leslie A., Stewart, David R., "Special Forum: Best Professional Development Experiences, Spring 2014," 7:2 (2014), 26-30. https://doi.org/10.31046/tl.v7i2.344

Campbell, Donna R., “A Compendium of Musical Instruments and Instrumental Terminology in the Bible,” 3:2 (2010), 48-50. https://doi.org/10.31046/tl.v3i2.151

Chappel, James, “Ronald Knox: A Bibliographic Essay,” 1:2 (2008), 49-53. https://doi.org/10.31046/tl.v1i2.44

Coates, Carolyn K., “The Curious Case of a ‘Mayflower Bible’,” 1:2 (2008), 7-15. https://doi.org/10.31046/ tl.v1i2.59

Cox, David E., “Libraries and Archives: A Comparative Study,” 7:1 (2014), 67. https://doi.org/10.31046/ tl.v7i1.310

-—-, “Personenlexikon zum Zweiten Vatikanischen Konzil,” 8:1 (2015), 79-80. https://doi.org/10.31046/ $\underline{\text { tl.v8i1.339 }}$

-—-, “Muhammad in History, Thought, and Culture,” 8:2 (2015), 59-60. https://doi.org/10.31046/tl.v8i2.376

-_-, “The Annotated Luther, Volume I: The Roots of Reform,” 9:2 (2016), 30. https://doi.org/10.31046/ tl.v9i2.450

Crawford, Eileen, “The Perennial Question and a Radical Response: The Student Bibliographer Program in the Vanderbilt Divinity Library,” 6:2 (2013), 9-19. https://doi.org/10.31046/tl.v6i2.273

Croissant, Charles R., "FRBR and RDA: What They Are and How They May Affect the Future of Libraries,” 5:2 (2012), 6-22. https://doi.org/10.31046/tl.v5i2.234

Crowley, Eileen D., "Participatory Cultures and Implications for Theological Education,” 6:1 (2013), 60-68. https://doi.org/10.31046/tl.v6i1.251

Crown, Ronald W., "Welcome to Our Third Issue of Theological Librarianship,” 2:1 (2009), iii. https://doi. org/10.31046/tl.v2i1.93

-_-, “Why Write for Peer Review?” 5:2 (2012), iii. https://doi.org/10.31046/tl.v5i2.246

--- and Stewart, David R., “Why Theological Librarianship?” 1:1 (2008), 4. https://doi.org/10.31046/tl.v1i1.35

--- and Stewart, David R., “Our Second Issue,” 1:2 (2008), 3. https://doi.org/10.31046/tl.v1i2.65

--- and Stewart, David R., “Two Years On,” 2:2 (2009), iii. https://doi.org/10.31046/tl.v2i2.124

--- and Stewart, David R., “Change, Challenge, Opportunity - a Forum on Electronic Journals,” 2:2 (2009), 36. https://doi.org/10.31046/tl.v2i2.122 
-—- and Stewart, David R., “Why Write?” 3:1 (2010), iii. https://doi.org/10.31046/tl.v3i1.147

-—- and Stewart, David R., “From the Co-Editors,” 3:2 (2010), iii. https://doi.org/10.31046/tl.v3i2.170

--_ and Stewart, David R., “Authors on Authoring,” 5:1 (2012), iii. https://doi.org/10.31046/tl.v5i1.219

-_- and Stewart, David R., “Introduction: The Reshaping of Libraries,” 5:1 (2012), 8. https://doi.org/10.31046/ tl.v5i1.220

Cunningham, Paige Comstock, Miller, Rebecca Louise, Denneque, Seblewongel A., "Encouraging a Positive Outlook: The Benefits of Appreciative Inquiry in a Theological Library,” 7:1 (2014), 47-55. https://doi. org/10.31046/tl.v7i1.312

Darlack, James Marion, “Diktuon: Drupal - CMS and Beyond,” 6:2 (2013), 1-3. https://doi.org/10.31046/ tl.v6i2.304

-—-, “The Baker Illustrated Bible Dictionary," 7:1 (2014), 68-69. https://doi.org/10.31046/tl.v7i1.319

-_-, “Web Review: Perseus Digital Library,” 9:1 (2016), 11-15. https://doi.org/10.31046/tl.v9i1.423

-_-, “New International Dictionary of New Testament Theology and Exegesis,” 9:1 (2016), 50-51. https:// doi.org/10.31046/tl.v9i1.421

-_-, Butler, Rebecca, Pakala, James C., Day, Donald E., Kroll, Anna Lois, Amodeo, Anthony, Engelson, Leslie A., Stewart, David R., "Special Forum: Best Professional Development Experiences, Spring 2014," 7:2 (2014), 26-30. https://doi.org/10.31046/tl.v7i2.344

Darling, Kay, “Innovative Solutions for Building Community in Academic Libraries,” 9:2 (2016), 31-32. https:// doi.org/10.31046/tl.v9i2.446

Daught, Gary, “Religious Studies Journals in Beall's List,” 10:1 (2017), 33-39. https://doi.org/10.31046/ tl.v10i1.481

-—-, Bennett, Miranda H., and Estelle-Holmer, Suzanne M., “A New Era for Theological Librarianship,” 9:2 (2016), iii. https://doi.org/10.31046/tl.v9i2.448

Day, Donald E., “Encyclopedia of Demons in World Religions and Cultures,” 5:2 (2012), 80-81. https://doi. org/10.31046/tl.v5i2.227

---, Butler, Rebecca, Pakala, James C., Darlack, James Marion, Kroll, Anna Lois, Amodeo, Anthony, Engelson, Leslie A., Stewart, David R., “Special Forum: Best Professional Development Experiences, Spring 2014,” 7:2 (2014), 26-30. https://doi.org/10.31046/tl.v7i2.344

Dearborn, Virginia E. and Henke, Kenneth W., "Profiles: Aspiring Vision and Attention to Detail: Kenneth Sperber Gapp (1905-1966)," 8:2 (2015), 1-3. https://doi.org/10.31046/tl.v8i2.396

DeBoer, Jacob A., “America’s Public Bible,” 11:1 (2018), 53-54. https://doi.org/10.31046/tl.v11i1.505

Deeds, Leland, “Diktuon: Purchasing at the Point of Need: An Acquisitions Pilot Project,” 7:1 (2014), 1-2. https://doi.org/10.31046/tl.v7i1.315

Dekker, Jennifer, “Religious Nationalism: A Reference Handbook,” 7:1 (2014), 70-71. https://doi.org/10.31046/ tl.v7i1.320

DeLong, Linwood, "Reference Guide to Christian Missionary Societies in China and Christianity in China: A Scholar's Guide to Resources in the Libraries and Archives of the United States,” 3:2 (2010), 51-53. https:// doi.org/10.31046/tl.v3i2.145 
Denneque, Seblewongel A., Cunningham, Paige Comstock and Miller, Rebecca Louise, "Encouraging a Positive Outlook: The Benefits of Appreciative Inquiry in a Theological Library,” 7:1 (2014), 47-55. https://doi. org/10.31046/tl.v7i1.312

Detar, Melody Diehl, “Theological Librarianship from a Distance,” 8:2 (2015), 11-15. https://doi.org/10.31046/ tl.v8i2.390

Dittrich, Nicole C., “The Encyclopedia of Caribbean Religions,” 7:2 (2014), 56-57. https://doi.org/10.31046/ tl.v7i2.329

Dries, Angelyn, “'Awash in a Sea of Archives': Key Research Sources in the United States for the Study of Mission and World Christianity," 5:2 (2012), 23-28. https://doi.org/10.31046/tl.v5i2.232

Dunkly, James and Bergant, Diane, “Encyclopedia of the Bible and Its Reception,” 2:2 (2009), 98-102. https:// doi.org/10.31046/tl.v2i2.117

Durham, Erica, “Web Reviews: Religious Institute-Denominational Statements,” 4:1 (2011), 1-2. https://doi. org/10.31046/tl.v4i1.191

Eberts, Susan, “Profiles: A Giant in the Land: H. Lucille Hager, 1924-2004,” 8:1 (2015), 1-3. https://doi. org/10.31046/tl.v8i1.373

Editorial Team, “A Note to Prospective Authors,” 1:1 (2008), 5. https://doi.org/10.31046/tl.v1i1.39

Elder, Jane Lenz, “Finding Time to Write,” 10:1 (2017), 1. https://doi.org/10.31046/tl.v10i1.471

Eldevik, Bruce Eugene, “Encyclopedia of Missions and Missionaries," 1:2 (2008), 80-82. https://doi. org/10.31046/tl.v1i2.50

-_-, “The Oxford Companion to the Book," 3:2 (2010), 54-56. https://doi.org/10.31046/tl.v3i2.156

-_-, “Teaching the History of the Bible as Book," 9:1 (2016), 38-44. https://doi.org/10.31046/tl.v9i1.427

Elia, Anthony J., “An Historical Assessment of the Narrative Uses of the Words 'Kabbalah,' 'Cabala,' and 'Qabala/h': Discerning the Differences for Theological Libraries,” 2:2 (2009), 11-23. https://doi. org/10.31046/tl.v2i2.111

-_-, “An Unknown Exegete: Uncovering the Biblical Scholarship of Elizabeth Barrett Browning,” 7:1 (2014), 8-20. https://doi.org/10.31046/tl.v7i1.266

Eliceiri, Rebecca Klemme, “An Invisible Wall: The Relationship Between Congregational and Seminary Libraries in the United States," 7:1 (2014), 28-29. https://doi.org/10.31046/tl.v7i1.324

Ellis, Teresa Cardin, “Church-State Issues in America Today,” 1:2 (2008), 83-85. https://doi.org/10.31046/ $\underline{\text { tl.v1i2.53 }}$

---, "A Remarkable Collection of Rare Scriptures in a Small University Library Setting,” 6:2 (2013), 20-28. https://doi.org/10.31046/tl.v6i2.298

Engelson, Leslie A., Butler, Rebecca, Pakala, James C., Darlack, James Marion, Day, Donald E., Kroll, Anna Lois, Amodeo, Anthony, Stewart, David R., "Special Forum: Best Professional Development Experiences, Spring 2014,” 7:2 (2014), 26-30. https://doi.org/10.31046/tl.v7i2.344

Estelle-Holmer, Suzanne M., “Web Reviews: ETANA,” 1:2 (2008), 6. https://doi.org/10.31046/tl.v1i2.64

---, “Encyclopaedia Islamica,” 2:2 (2009), 103-104. https://doi.org/10.31046/tl.v2i2.119

---, “Profiles: John Albert Bollier, 1927-2010,” 6:2 (2013), 4-6. https://doi.org/10.31046/tl.v6i2.305

---, Bennett, Miranda H., and Daught, Gary, “A New Era for Theological Librarianship,” 9:2 (2016), iii. https:// doi.org/10.31046/tl.v9i2.448 
Estes, James Andrew, “Church History: An Introduction to Research Methods and Resources,” 11:1 (2018), 55-57. https://doi.org/10.31046/tl.v11i1.504

Evans, Justin J., “Dictionary of the Old Testament: Prophets,” 7:2 (2014), 58-59. https://doi.org/10.31046/ tl.v7i2.321

Ewalt, Jillian and Soule, Stephanie L., “The John Stokes and Mary’s Gardens Collection,” 9:2 (2016), $23-27$. https://doi.org/10.31046/tl.v9i2.439

Falciani-White, Nancy K., "Running with Perseverance: The Theological Library's Challenge of Keeping Pace With Changing Students,” 1:2 (2008), 16-27. https://doi.org/10.31046/tl.v1i2.61

Fitzgerald, Allan, “Bibliographic Essay: Augustine of Hippo,” 8:2 (2015), 46-55. https://doi.org/10.31046/ tl.v8i2.383

Ford, Jim, Robertson, Terry Dwain and Burt, Merlin D., “The Center for Adventist Research at Andrews University,” 8:1 (2015), 24-29. https://doi.org/10.31046/tl.v8i1.368

Fowler, Jason, “An Interpretive Lexicon of New Testament Greek,” 10:1 (2017), 45. https://doi.org/10.31046/ tl.v10i1.467

--_, “Library Services for the North Carolina Field Minister Program,” 11:2 (2018), 13. https://doi. org/10.31046/tl.v11i2.524

Friede, Eric, “Atlas of Global Christianity,” 3:1 (2010), 53-56. https://doi.org/10.31046/tl.v3i1.137

Frost, Ellen, “Guide to Islamist Movements,” 5:1 (2012), 79-80. https://doi.org/10.31046/tl.v5i1.208

Ganski, Kate L., “An Evaluation of the Accessibility of E-resources from Theological Library Websites,” 1:1 (2008), 38-45. https://doi.org/10.31046/tl.v1i1.14

---, "Marketing Today’s Academic Library: A Bold New Approach to Communicating with Students," 2:2 (2009), 105-106. https://doi.org/10.31046/tl.v2i2.100

Garrett, J. Michael, “The Encyclopedia of Christian Civilization,” 5:2 (2012), 82-84. https://doi.org/10.31046/ tl.v5i2.231

Garrett, Jeffrey, "Wood, Flour, Journal: How the Electronic Turn Has Affected the Way Journals are Found, Used, and Read,” 2:2 (2009), 37-42. https://doi.org/10.31046/tl.v2i2.97

-- , “Klostersturm and Secularization in Central Europe: What Happened to the Libraries?” 8:1 (2015), 61-69. https://doi.org/10.31046/tl.v8i1.372

Gerber, Kent T. K., “Diktuon: Getting Involved With the Digital Humanities in Theology, Biblical Studies, and Religious Studies,” 9:1 (2016), 5-10. https://doi.org/10.31046/tl.v9i1.420

Getahun, Verena and Keillor, William A., "Counting the Costs of Acquisitions: Using Cost-Benefit Analysis in a Seminary and University Library,” 2:2 (2009), 24-35. https://doi.org/10.31046/tl.v2i2.108

Gonzalez, Lisa, “Oxford Biblical Studies Online,” 2:1 (2009), 91-93. https://doi.org/10.31046/tl.v2i1.85

-—-, “E-Book Collections,” 3:1 (2010), 57. https://doi.org/10.31046/tl.v3i1.136

---, "Encyclopedia of Religion and Film,” 6:1 (2013), 80-82. https://doi.org/10.31046/tl.v6i1.263

-- - "Ministers on the Lecture Circuit: Education, Entertainment and Religion in Early 20th Century America," 7:1 (2014), 21-27. https://doi.org/10.31046/tl.v7i1.314

--—, “Apps for Librarians,” 8:2 (2015), 61-62. https://doi.org/10.31046/tl.v8i2.403 
---, “T\&T Clark Handbook to Social Identity in the New Testament,” 9:1 (2016), 59-60. https://doi. org/10.31046/tl.v9i1.426

---, “Launching an Open Access Journal - Can You Make the Investment?” 10:1 (2017), 41-42. https://doi. org/10.31046/tl.v10i1.483

Goodwin, Shawn Virgil, “Hebrew Language Resources,” 12:1 (2019), 24-39. https://doi.org/10.31046/ tl.v12i1.493

---, “A Biblical Hebrew Reference Grammar,” 12:1 (2019), 65-67. https://doi.org/10.31046/tl.v12i1.541

Grafton, Karla Fackler, “Doing Theological Research: An Introductory Guide for Survival in Theological Education,” 4:1 (2011), 101-102. https://doi.org/10.31046/tl.v4i1.179

-—-, “Eerdmans Dictionary of Early Judaism,” 4:1 (2011), 103-104. https://doi.org/10.31046/tl.v4i1.184

-—-, “Crossroads of War,” 8:2 (2015), 63-64. https://doi.org/10.31046/tl.v8i2.392

Graham, M. Patrick, “Framing Books and Reading: An Exploration of Sixteenth Century Title Borders,” 6:2 (2013), 53-62. https://doi.org/10.31046/tl.v6i2.291

Griffin, Jeff, “Prison Theological Librarianship,” 11:2 (2018), 14. https://doi.org/10.31046/tl.v11i2.508

Gucker, Jacob W., “The Personal Librarian: Enhancing the Student Experience,” 8:2 (2015), 65-66. https:// doi.org/10.31046/tl.v8i2.402

Gundry, Jenifer, “Incorporating Concepts of Hospitality Into Theological Library Assessment,” 8:1 (2015), 10-15. https://doi.org/10.31046/tl.v8i1.366

-- , Senapatiratne, Timothy and Trott, Garrett, “Citation Analysis and Its Potential In Theological Libraries," 8:2 (2015), 16-21. https://doi.org/10.31046/tl.v8i2.389

Guyette, Fred, “An Open Access Source for the Study of Religion and the Law: The Proceedings of the Old Bailey: London's Central Criminal Court 1674-1913,” 1:2 (2008), 28-37. https://doi.org/10.31046/tl.v1i2.60

---, "Religion and the Law in America,” 2:1 (2009), 94-95. https://doi.org/10.31046/tl.v2i1.55

-_-, “The Literature of Ecclesiology: A Ten Year Retrospective,” 4:1 (2011), 75-90. https://doi.org/10.31046/ tl.v4i1.146

Guzman, Alvaro Perez, "The Library of the Universidad Bíblica Latinoamericana: 75th Anniversary in the Midst of Changes," 4:1 (2011), 8-15. https://doi.org/10.31046/tl.v4i1.195

-_-, “Diccionario de Pensadores Cristianos,” 5:1 (2012), 81-82. https://doi.org/10.31046/tl.v5i1.212

Hall, Rebekah, “The James E. Rolfing Memorial Library, Trinity International University,” 5:1 (2012), 9-11. https://doi.org/10.31046/tl.v5i1.207

Hamilton, Barry W., “Action Research for Theological Librarians,” 1:1 (2008), 54-59. https://doi.org/10.31046/ tl.v1i1.19

---, “Melton's Encyclopedia of American Religions," 2:2 (2009), 107-108. https://doi.org/10.31046/tl.v2i2.103

Hanson, Mark, “Encyclopedia of Psychology and Religion,” 3:2 (2010), 57-59. https://doi.org/10.31046/ tl.v3i2.167

Hanson, Susanah J., “The Oxford Encyclopedia of the Books of the Bible,” 5:2 (2012), 85-87. https://doi. org/10.31046/tl.v5i2.222

---, “The Marjory Stanway Collection of African Language Materials at Trinity School for Ministry,” 6:1 (2013), 16-20. https://doi.org/10.31046/tl.v6i1.259 
Harper, Wakefield, “The Oxford Handbook of Interdisciplinarity,” 5:2 (2012), 88-89. https://doi.org/10.31046/ tl.v5i2.228

Hartman, Robin R., "Diktuon: Providing Library Services in the Cloud: New Benefits Realized, New Skills Required,” 7:2 (2014), 6-8. https://doi.org/10.31046/tl.v7i2.348

Harty, Kathy, “Historical Dictionary of Catholicism,” 6:2 (2013), 67-68. https://doi.org/10.31046/tl.v6i2.302

Hayes, Elyse, “New Catholic Encyclopedia Supplement 2009,” 2:2 (2009), 109-111. https://doi.org/10.31046/ tl.v2i2.115

-_-, “Concise American Catholic Encyclopedia,” 6:1 (2013), 83-85. https://doi.org/10.31046/tl.v6i1.261

Heintzelman, Matthew, “Profiles: Father Oliver Kapsner, OSB (1902-1991) - A Life in Libraries,” 5:1 (2012), 4-6. https://doi.org/10.31046/tl.v5i1.216

Henke, Kenneth W. and Dearborn, Virginia E., "Profiles: Aspiring Vision and Attention to Detail: Kenneth Sperber Gapp (1905-1966)," 8:2 (2015), 1-3. https://doi.org/10.31046/tl.v8i2.396

Hidalgo, Ann, Phillips, Thomas E. and Baker, Drew, "Introducing the Open Access Digital Theological Library (OADTL): Creating the World's First Entirely Open Access Library in Religious Studies,” 11:2 (2018), 1-3. https://doi.org/10.31046/tl.v11i2.520

Hogan, Derek K., “Encyclopedia of the Historical Jesus,” 2:1 (2009), 96-97. https://doi.org/10.31046/tl.v2i1.76

Hook, William J., Myers, Sara J. and Taylor, Sharon A., "Effective Leadership in Tough Times: Three Essays,” 2:1 (2009), 20-34. https://doi.org/10.31046/tl.v2i1.92

Hotchkiss, Valeri, “Profiles: A Pilgrim’s Progress: Decherd Turner, 1922-2002,” 7:1 (2014), 3-5. https://doi. org/10.31046/tl.v7i1.326

Hughes, Barnaby, “Peer-reviewing the Publishers: the Scholarly Open Access Appeals Board, 2013-2016," 10:1 (2017), 27-32. https://doi.org/10.31046/tl.v10i1.480

-_-, "Cruising the Library: Perversities in the Organization of Knowledge,” 10:1 (2017), 46-47. https://doi. org/10.31046/tl.v10i1.470

Iwaskov, Tracy Powell, "Handbook of Theological Education in World Christianity," 4:1 (2011), 110-111. https://doi.org/10.31046/tl.v4i1.185

Jackson, Andrea, Wiseman, Christine and Ost, Brad, "Funding the Future of African American Religion Archival Collections,” 9:1 (2016), 16-21. https://doi.org/10.31046/tl.v9i1.409

Jaeger, John David, “Encyclopedia of Philosophers on Religion,” 2:1 (2009), 98-100. https://doi.org/10.31046/ tl.v2i1.80

Jaeger, John David, “Faith Across Time,” 8:1 (2015), 81-82. https://doi.org/10.31046/tl.v8i1.354

Jefford, Clayton N., “The Librarian's Guide to the Apostolic Fathers,” 5:2 (2012), 59-66. https://doi.org/10.31046/ tl.v5i2.224

Jiwa, Nawazali Alibhai, “Towards an Online Searchable Bibliographic Database for Ismā ‘̄ilì Studies,” 11:1 (2018), 37-50. https://doi.org/10.31046/tl.v11i1.478

Jones, Arun W., "Expressions and Encounters: Experiencing the Histories and Theologies of African Christianity in the Collections of Pitts Theology Library: A Critical Evaluation of an Exhibition,” 12:1 (2019), 13-15. https://doi.org/10.31046/tl.v12i1.544

Jones, Jonathan, “Encyclopedia of Love in World Religions,” 2:1 (2009), 101-103. https://doi.org/10.31046/ $\underline{\text { tl.v2i1.81 }}$ 
Kadel, Andrew G., “The Christoph Keller, Jr. Library, General Theological Seminary, New York,” 5:1 (2012), 12-15. https://doi.org/10.31046/tl.v5i1.210

Kaihoi, Scott, “Christian Librarians and the Ethics of the Library Bill of Rights,” 8:1 (2015), 42-60. https://doi. org/10.31046/tl.v8i1.353

Kamilos, Charles D. and Birch, Rodney, "Library Research Instruction for Doctor of Ministry Students: Outcomes of Instruction Provided by a Theological Librarian and by a Program Faculty Member," 7:1 (2014), 38-46. https://doi.org/10.31046/tl.v7i1.325

Keck, Andrew J., “Diktuon: Digital Repositories and Theological Libraries,” 1:1 (2008), 6-7. https://doi. org/10.31046/tl.v1i1.17

-—-, “Diktuon: Bibliographic Managers,” 1:2 (2008), 4-5. https://doi.org/10.31046/tl.v1i2.62

-_-, “Diktuon: Virtual Reference,” 2:1 (2009), 1-2. https://doi.org/10.31046/tl.v2i1.83

-—-, “Diktuon: Finding e-books,” 3:1 (2010), 1-3. https://doi.org/10.31046/tl.v3i1.143

-_-, “Diktuon: Mobile Devices and Libraries,” 5:1 (2012), 1-3. https://doi.org/10.31046/tl.v5i1.221

-_-, “T\&T Clark Companion to Methodism,” 5:1 (2012), 83-84. https://doi.org/10.31046/tl.v5i1.215

-_-, “How Theological Librarianship Came to Be, and Came to Be Open-Access,” 10:1 (2017), 40. https://doi. org/10.31046/tl.v10i1.482

---, “Theological Libraries and Scholarly Publishing in Religion and Theology,” 11:2 (2018), 27-37. https:// doi.org/10.31046/tl.v11i2.518

Keeney, Donald, “The Encyclopedia of Christian Literature,” 3:2 (2010), 60-62. https://doi.org/10.31046/ tl.v3i2.155

Keillor, William A. and Getahun, Verena, "Counting the Costs of Acquisitions: Using Cost-Benefit Analysis in a Seminary and University Library,” 2:2 (2009), 24-35. https://doi.org/10.31046/tl.v2i2.108

Kemmis, Barbara, “The Theological Librarian’s Role in Fundraising,” 2:1 (2009), 57-66. https://doi. org/10.31046/tl.v2i1.77

Ketchaver, Karen G., “Father Charles E. Coughlin - the 'Radio Priest' of the 1930s,” 2:2 (2009), 81-88. https:// doi.org/10.31046/tl.v2i2.112

Kettner, Megan, “RDA Toolkit,” 4:1 (2011), 105-106. https://doi.org/10.31046/tl.v4i1.175

Kiczek, Steven Allen, "Influence of the Fathers of the Church on Recent Catholic Conversion Narratives," 5:1 (2012), 56-66. https://doi.org/10.31046/tl.v5i1.197

Kiyaga, John, “Uganda Christian University: A Center of Excellence in the Heart of Africa-An Overview of the UCU Library,” 4:1 (2011), 16-21. https://doi.org/10.31046/tl.v4i1.193

Klemme, Rebecca, “Encyclopedia of Gender and Society,” 4:1 (2011), 107-109. https://doi.org/10.31046/ tl.v4i1.169

Knapp, Kathryn, “Six Segments on Military Ministry,” 3:1 (2010), 27-30. https://doi.org/10.31046/tl.v3i1.134

Kokolus, Cait C., “Encyclopedia of Religious and Spiritual Development,” 1:2 (2008), 86-87. https://doi. org/10.31046/tl.v1i2.43

---, "Dictionary of Christian Spirituality,” 5:2 (2012), 90-91. https://doi.org/10.31046/tl.v5i2.226

Kolb, Daniel, “Australasian Religion Index (ARI),” 1:2 (2008), 88. https://doi.org/10.31046/tl.v1i2.54 
Kordesh, Kathleen, “The Work of Evelyn Fox Keller as a Resource for Study in Science and Religion,” 1:2 (2008), 54-59. https://doi.org/10.31046/tl.v1i2.56

Kroll, Anna Lois, Butler, Rebecca, Pakala, James C., Darlack, James Marion, Day, Donald E., Amodeo, Anthony, Engelson, Leslie A., Stewart, David R., "Special Forum: Best Professional Development Experiences, Spring 2014,” 7:2 (2014), 26-30. https://doi.org/10.31046/tl.v7i2.344

Kuykendall, Michael, “Going a Step Beyond-Websites with More than Just Bibles,” 3:2 (2010), 22-26. https:// doi.org/10.31046/tl.v3i2.159

Leahy, Elizabeth A., “The New Westminster Dictionary of Church History,” 3:1 (2010), 58-59. https://doi. org/10.31046/tl.v3i1.139

Lemna, Keith Edward, “Pope Francis’ Strong Thought,” 7:2 (2014), 45-53. https://doi.org/10.31046/tl.v7i2.343

Lester, G. Brooke, “Inner-Biblical Allusion,” 2:2 (2009), 89-93. https://doi.org/10.31046/tl.v2i2.110

Lillard, Justin Matthew, “The Oxford Handbook of Christianity and Economics,” 8:1 (2015), 83-84. https:// doi.org/10.31046/tl.v8i1.355

Limpitlaw, Amy, “Web Reviews: Counterbalance,” 2:1 (2009), 5-7. https://doi.org/10.31046/tl.v2i1.82

---, "Web Reviews: Theological Perspectives of the Reformation,” 2:2 (2009), 9-10. https://doi.org/10.31046/ tl.v2i2.116

-_-, "Web Reviews: The Gifford Lectures-Over 100 Years of Renowned Lectures on Natural Theology," 3:1 (2010), 6. https://doi.org/10.31046/tl.v3i1.140

Lincoln, Laura Marie and Lincoln, Timothy Dwight, "From Intention to Composition: How Seminarians Conceptualize Research,” 4:1 (2011), 41-67. https://doi.org/10.31046/tl.v4i1.178

Lincoln, Timothy Dwight, “The Information: A History, A Theory, A Flood,” 5:1 (2012), 85-86. https://doi. org/10.31046/tl.v5i1.201

-- - "Reading and E-reading for Academic Work: Patterns and Preferences in Theological Studies and Religion,” 6:2 (2013), 34-52. https://doi.org/10.31046/tl.v6i2.293

--- and Lincoln, Laura Marie, “From Intention to Composition: How Seminarians Conceptualize Research,” 4:1 (2011), 41-67. https://doi.org/10.31046/tl.v4i1.178

Lipton, Saundra, “Encyclopedia of Women in Today's World,” 5:1 (2012), 87-88. https://doi.org/10.31046/ tl.v5i1.218

Litwak, Kenneth D., “Comparative Review of Three Bible Atlases,” 3:2 (2010), 63-66. https://doi.org/10.31046/ tl.v3i2.165

-—-, "Crash Course in Library Services to People with Disabilities,” 7:2 (2014), 60-61. https://doi.org/10.31046/ tl.v7i2.328

Loyd, Roger, “Profiles: Doralyn Joanne Hickey, 1929-1987: An Appreciation,” 6:1 (2013), 4-6. https://doi. org/10.31046/tl.v6i1.256

Lubetski, Edith and Lubetski, Meir, "Considerations in Preparing a Biblical Bibliography: Case Study: The Scroll of Esther,” 3:1 (2010), 31-39. https://doi.org/10.31046/tl.v3i1.129

Lubetski, Meir and Lubetski, Edith, “Considerations in Preparing a Biblical Bibliography: Case Study: The Scroll of Esther,” 3:1 (2010), 31-39. https://doi.org/10.31046/tl.v3i1.129

Maher, Diane, "Greater Than the Sum of Its Parts: The Shared Wealth of Scholarly Resources in the Catholic Portal," 9:2 (2016), 12-14. https://doi.org/10.31046/tl.v9i2.438 
Malone, David Brian, “'Raising an Ebenezer’: Archives as a Religious Means of Remembering,” 8:1 (2015), 16-19. https://doi.org/10.31046/tl.v8i1.369

Malone, David Brian, "Providing Library Services to Prisoners: Calvin College and Calvin Seminary at Handlon Correctional Facility,” 11:2 (2018), 15. https://doi.org/10.31046/tl.v11i2.514

Manzoor, Romana G., “The Illustrated Guide to Islam,” 6:2 (2013), 69-70. https://doi.org/10.31046/tl.v6i2.292

Marcus, Sara, “The Encyclopedia of Jews in the Islamic World,” 3:2 (2010), 67-68. https://doi.org/10.31046/ tl.v3i2.166

Masuchika, Glenn Norio, “Zen Garden and No Zen Garden: A Bibliographic Essay,” 5:1 (2012), 67-70. https:// doi.org/10.31046/tl.v5i1.204

Mathews, Edward George, “Ephrem the Syrian: A Syriac Poet in Armenian Verse,” 5:1 (2012), 71-76. https:// doi.org/10.31046/tl.v5i1.205

Mayer, Robert J., “Theological Librarians and Collection Management: Collaborative Policy Development,” 11:2 (2018), 8-11. https://doi.org/10.31046/tl.v11i2.530

Mayo, David, “Web Review: Hymnary.org - Comprehensive Index of Hymns and Hymnals,” 5:2 (2012), 4-5. https://doi.org/10.31046/tl.v5i2.233

McIntosh-Doty, Mikail, “Encyclopedia of Catholic Social Thought, Social Science, and Social Policy,” 1:1 (2008), 68-70. https://doi.org/10.31046/tl.v1i1.20

McLaurin, III, Dougald W., “Fortress Commentary on the Bible,” 8:2 (2015), 67-68. https://doi.org/10.31046/ tl.v8i2.400

McMahon, Melody Layton, “Librarians, Publishers, and Theological Reference Resources: A Way Forward,” 2:1 (2009), 8-19. https://doi.org/10.31046/tl.v2i1.86

---, “Theological Librarianship: An Unapologetic Apology,” 3:1 (2010), 7-14. https://doi.org/10.31046/ tl.v3i1.131

-_-, “Three Catholic Libraries in London,” 4:1 (2011), 22-31. https://doi.org/10.31046/tl.v4i1.192

-_-, “Mentoring in the Library: Building for the Future,” 5:1 (2012), 89-90. https://doi.org/10.31046/tl.v5i1.182

-_-, “Diktuon: The Library as Publisher? Is It Possible for a Small Library?” 8:1 (2015), 4-6. https://doi. org/10.31046/tl.v8i1.365

-_-, “The Canterbury Dictionary of Hymnology,” 8:1 (2015), 85-86. https://doi.org/10.31046/tl.v8i1.356

-_-, “Profiles: Fr. Simeon Daly, OSB,” 9:1 (2016), 1-4. https://doi.org/10.31046/tl.v9i1.415

McManus, Jean C., “Catholic Pamphlets at the Hesburgh Libraries,” 9:2 (2016), 15-18. https://doi.org/10.31046/ tl.v9i2.441

McMullen, Kenneth, "Religion and Violence: An Encyclopedia of Faith and Conflict from Antiquity to the Present,” 5:1 (2012), 91-93. https://doi.org/10.31046/tl.v5i1.199

---, “Encyclopedia of English Language Bible Versions,” 6:2 (2013), 71-73. https://doi.org/10.31046/ tl.v6i2.283

-—-, “Christian Theology: the Classics,” 8:2 (2015), 69-70. https://doi.org/10.31046/tl.v8i2.404

Michael, Joshua, “Murphy Memorial Library, Baptist Bible College and Seminary,” 5:1 (2012), 16-18. https:// doi.org/10.31046/tl.v5i1.209

Miller, Elizabeth Young, “STEP Bible,” 11:1 (2018), 58-59. https://doi.org/10.31046/tl.v11i1.503 
Miller, Rebecca Louise, “Web Review: The Jonathan Edwards Center at Yale University,” 5:1 (2012), 7. https:// doi.org/10.31046/tl.v5i1.206

---, Denneque, Seblewongel A., and Cunningham, Paige Comstock, "Encouraging a Positive Outlook: The Benefits of Appreciative Inquiry in a Theological Library,” 7:1 (2014), 47-55. https://doi.org/10.31046/ tl.v7i1.312

Mitchell, Michael R., “Christian Catechetical Texts,” 5:2 (2012), 92-94. https://doi.org/10.31046/tl.v5i2.243

MoChridhe, Race J., “Twenty Years of Theological Markup Languages: A Retro- and Prospective,” 12:1 (2019), 40-49. https://doi.org/10.31046/tl.v12i1.523

Moll, Kirk A., “Jewish Annotated New Testament,” 5:2 (2012), 95-96. https://doi.org/10.31046/tl.v5i2.244

Mombo, Esther, "Expressions and Encounters: Experiencing the Histories and Theologies of African Christianity in the Collections of Pitts Theology Library: A Visiting Scholar's Reflection,” 12:1 (2019), 16-23. https://doi.org/10.31046/tl.v12i1.543

Morris, Angela G., "Religious Celebrations: An Encyclopedia of Holidays, Festivals, Solemn Observances, and Spiritual Commemorations,” 5:2 (2012), 97-98. https://doi.org/10.31046/tl.v5i2.239

-_-, “New Routes to Library Success,” 9:2 (2016), 33-34. https://doi.org/10.31046/tl.v9i2.445

Mukunthan, Cumaraswamy Michael, “The Oxford Handbook of Early Christian Studies,” 2:2 (2009), 112-114. https://doi.org/10.31046/tl.v2i2.94

Murphy, Benjamin P., “The Qumran Visualization Project: Prospects for Digital Humanities in Theological Libraries,” 5:2 (2012), 29-38. https://doi.org/10.31046/tl.v5i2.240

Murphy, Ondrea M., “Pushing the Margins: Women of Color and Intersectionality in LIS,” 12:1 (2019), 61-62. https://doi.org/10.31046/tl.v12i1.540

Murrain, Shanee Yvette, “Web Review: The Association of Religion Data Archives,” 7:2 (2014), 4-5. https:// doi.org/10.31046/tl.v7i2.336

-_-, “The Oxford Handbook of African American Theology,” 10:1 (2017), 48-49. https://doi.org/10.31046/ tl.v10i1.468

Murray, Gregory P., "Featured Web Resource: Theological Commons,” 9:2 (2016), 1-4. https://doi.org/10.31046/ tl.v9i2.434

Myers, Sara J., Hook, William J. and Taylor, Sharon A., "Effective Leadership in Tough Times: Three Essays," 2:1 (2009), 20-34. https://doi.org/10.31046/tl.v2i1.92

Norlin, Dennis A., “Welcome to Theological Librarianship,” 1:1 (2008), 3. https://doi.org/10.31046/tl.v1i1.36

Norris, Tiffany Davis, “Information Literacy: Adaptability and Authenticity-Using the Next Generation's Powers for Good, Not Evil,” 2:2 (2009), 1-2. https://doi.org/10.31046/tl.v2i2.106

Nosek, Jason D., “Open Access Liturgical Resources for Judaism,” 6:2 (2013), 63-66. https://doi.org/10.31046/ tl.v6i2.265

Olley, Lorraine H., “Benedict Biscop: Benedictine, Builder, Bibliophile,” 7:1 (2014), 30-37. https://doi. org/10.31046/tl.v7i1.297

Osinski, Keegan, “There is Nothing New Under the Sun?: 'New Librarianship' and the Theological Library,” 8:1 (2015), 20-23. https://doi.org/10.31046/tl.v8i1.370

Oslund, Sandra, “Profiles: Quiet Person, Powerfully Loud Influence: Norris Magnuson (1932-2006),” 9:2 (2016), 9-11. https://doi.org/10.31046/tl.v9i2.433 
Ost, Brad, “Encyclopedia of Death \& the Human Experience," 3:1 (2010), 60-61. https://doi.org/10.31046/ tl.v3i1.132

-—-, "Words of Wisdom: A Philosophical Dictionary for the Perennial Tradition,” 6:1 (2013), 86-87. https:// doi.org/10.31046/tl.v6i1.248

-_-, "Religion and American Cultures: Tradition, Diversity, and Popular Expression, 2nd Edition,” 9:1 (2016), 47-48. https://doi.org/10.31046/tl.v9i1.418

---, “Better Standards for OA Journals,” 10:1 (2017), 25-26. https://doi.org/10.31046/tl.v10i1.479

---, Jackson, Andrea and Wiseman, Christine, "Funding the Future of African American Religion Archival Collections," 9:1 (2016), 16-21. https://doi.org/10.31046/tl.v9i1.409

Ostercamp, Matthew J., “A Case for Slow Reading," 7:2 (2014), 9-19. https://doi.org/10.31046/tl.v7i2.338

Pakala, James C., Butler, Rebecca, Darlack, James Marion, Day, Donald E., Kroll, Anna Lois, Amodeo, Anthony, Engelson, Leslie A., Stewart, David R., "Special Forum: Best Professional Development Experiences, Spring 2014,” 7:2 (2014), 26-30. https://doi.org/10.31046/tl.v7i2.344

Parker, T. R., “Ancient Christian Doctrine,” 2:2 (2009), 115-117. https://doi.org/10.31046/tl.v2i2.105

Penner, Katharina, “Information Behaviour(s) of Theologians: A Literature Review,” 2:1 (2009), 67-82. https:// doi.org/10.31046/tl.v2i1.79

- - , "Information Needs and Behaviours of Theology Students at the International Baptist Theological Seminary,” 2:2 (2009), 51-80. https://doi.org/10.31046/tl.v2i2.99

Pesch, Christine, “Encyclopedia of Buddhism,” 2:1 (2009), 104-105. https://doi.org/10.31046/tl.v2i1.63

---, “Encyclopedia of Hinduism,” 2:1 (2009), 106-107. https://doi.org/10.31046/tl.v2i1.87

-_-, “Encyclopedia of Taoism,” 2:1 (2009), 108-109. https://doi.org/10.31046/tl.v2i1.88

Phillips, Robert, “Leadership in Theological Education,” 11:2 (2018), 42-43. https://doi.org/10.31046/ $\underline{\text { tl.v11i2.527 }}$

--_, “Information Literacy: More to Learn-and Teach!” 2:1 (2009), 3-4. https://doi.org/10.31046/tl.v2i1.84

-—-, “Global Dictionary of Theology,” 2:2 (2009), 118-120. https://doi.org/10.31046/tl.v2i2.114

---, “Information Literacy: A Theological Librarian Reflects on Writers and Writing,” 3:1 (2010), 4-5. https:// doi.org/10.31046/tl.v3i1.144

---, "Information Literacy: Writing Based Research," 3:2 (2010), 4-5. https://doi.org/10.31046/tl.v3i2.164

-_-, “The Cambridge Dictionary of Christian Theology,” 6:1 (2013), 88-89. https://doi.org/10.31046/tl.v6i1.252

-_-, “The Oxford Encyclopaedia of South Asian Christianity,” 6:2 (2013), 74-76. https://doi.org/10.31046/ tl.v6i2.301

Phillips, Thomas E. and Baker, Drew, "Web Review: Working Virtually on the Texts and Manuscripts Behind the Document, II: Doing Jewish Bible/Old Testament Textual Criticism on the Web,” 8:2 (2015), 8-10. https://doi.org/10.31046/tl.v8i2.393

---, Baker, Drew and Hidalgo, Ann, "Introducing the Open Access Digital Theological Library (OADTL): Creating the World's First Entirely Open Access Library in Religious Studies,” 11:2 (2018), 1-3. https://doi. org/10.31046/tl.v11i2.520 
Phillips, Thomas E. and Bilby, Mark Glen, “Web Review: Working Virtually on the Text and Manuscripts Behind the Document: Doing New Testament Textual Criticism on the Web,” 8:1 (2015), 7-9. https://doi. org/10.31046/tl.v8i1.374

Powell, David R., “Dictionary of Major Biblical Interpreters,” 1:1 (2008), 65-67. https://doi.org/10.31046/ tl.v1i1.28

-_-, “The Bible and Handel's Messiah: Some Sources on Their Relation and Use,” 2:2 (2009), 94-97. https:// doi.org/10.31046/tl.v2i2.121

Presutti, Robert, “Toward a Greater Discourse: Issues in Religious Archives,” 3:1 (2010), 15-22. https://doi. org/10.31046/tl.v3i1.135

Rainey, Jon, “The Cinematic Savior: Jesus Films and Related Literature,” 3:2 (2010), 27-33. https://doi. org/10.31046/tl.v3i2.157

Redding, Jonathan David, “A Handbook to Old Testament Exegesis,” 11:1 (2018), 51-52. https://doi. org/10.31046/tl.v11i1.495

Reeves, Timothy Scott, “Seeing the Salzburgers in their Books,” 11:1 (2018), 1-11. https://doi.org/10.31046/ tl.v11i1.474

Rider, Jacqueline H., “The Church Club of New York Library,” 6:2 (2013), 29-33. https://doi.org/10.31046/ tl.v6i2.296

Roach, Jonathan Chad, "The Information Behavior of a New Generation: Children and Teens in the 21st Century," 6:2 (2013), 77-78. https://doi.org/10.31046/tl.v6i2.281

---, "Search Committees: A Comprehensive Guide to Successful Faculty, Staff, and Administrative Searches," 8:1 (2015), 87-88. https://doi.org/10.31046/tl.v8i1.351

Robertson, Terry Dwain, Burt, Merlin D. and Ford, Jim, “The Center for Adventist Research at Andrews University,” 8:1 (2015), 24-29. https://doi.org/10.31046/tl.v8i1.368

--- and Tan, Felipe E., “An Evaluation of the Classification Scheme for Adventists and Ellen White,” 11:1 (2018), 28-36. https://doi.org/10.31046/tl.v11i1.473

Rogers, Anthony D., “The Comprehensive Theological Bibliography: What is its Future?” 5:2 (2012), 48-58. https://doi.org/10.31046/tl.v5i2.203

Roland, Daniel R., "Using Sermon Text Archives to Investigate the Construction of Social Values: A Proposal for a Collaborative Research Agenda in Social Epistemology,” 5:1 (2012), 43-55. https://doi.org/10.31046/ tl.v5i1.188

-_-, “The Routledge Handbook of Research Methods in the Study of Religion,” 6:2 (2013), 79-80. https://doi. org/10.31046/tl.v6i2.285

Rosauer, Greg, “The SBL Handbook of Style, 2nd Edition,” 9:1 (2016), 54-56. https://doi.org/10.31046/tl.v9i1.424

Rosenbeck, Craig, “The Pastor's Library: An Annotated Bibliography of Biblical and Theological Resources for Ministry,” 11:2 (2018), 44. https://doi.org/10.31046/tl.v11i2.528

Rosser, Christopher Michael and Willis, Tamie, "Flip Over Research Instruction: Delivery, Assessment, and Feedback Strategies for ‘Flipped’ Library,” 9:1 (2016), 22-27. https://doi.org/10.31046/tl.v9i1.413

Rozear, Hannah, “Diktuon: Web-based Statistics Trackers,” 5:2 (2012), 1-3.https://doi.org/10.31046/tl.v5i2.245

-_-, "A Guide for Writing about Theology and Religion,” 6:2 (2013), 81-82. https://doi.org/10.31046/tl.v6i2.272 
Rzeznik, Thomas F., “The Historical Value of Parish Histories,” 9:2 (2016), 19-22. https://doi.org/10.31046/ tl.v9i2.442

Saleh, Adam Gambo and Abu Bakar, Ahmed Bakeri, "Information Seeking Behavior of the Ulama in Relation to Preaching and Counseling Roles in Nigeria," 6:1 (2013), 29-46. https://doi.org/10.31046/tl.v6i1.177

Saner, Eileen K., “Library of the Associated Mennonite Biblical Seminary,” 5:1 (2012), 19-22. https://doi. org/10.31046/tl.v5i1.213

Saxton, Filomena, “Latinos’ Informational Needs in Attaining Accredited Theological Education,” 7:2 (2014), 20-25. https://doi.org/10.31046/tl.v7i2.342

Saxton, Micah D., “A Gentle Introduction to Topic Modeling Using Python,” 11:1 (2018), 18-27. https://doi. org/10.31046/tl.v11i1.506

Schemper, Lugene L., “Profiles: Bibliographer Extraordinaire: Peter De Klerk, 1927-1997,” 7:2 (2014), 1-3. https://doi.org/10.31046/tl.v7i2.345

Schmersal, David Edward, “Esther: A Handbook on the Hebrew Text," 9:1 (2016), 45-46. https://doi. org/10.31046/tl.v9i1.417

Schottler, Sophie, “Routledge Companion to Christian History,” 1:2 (2008), 89-90. https://doi.org/10.31046/ tl.v1i2.52

Schroeder, Joy, “Encyclopedia of Contemporary Christian Music: Pop, Rock, and Worship,” 3:1 (2010), 62-63. https://doi.org/10.31046/tl.v3i1.130

-_-, “The Bible in Music: A Dictionary of Songs, Works, and More,” 9:2 (2016), 35-36. https://doi.org/10.31046/ tl.v9i2.428

Schwab, Juliet Crawford, “Web Reviews: Monachos.net-Orthodoxy Through Patristic, Monastic, and Liturgical Study," 3:2 (2010), 6-7. https://doi.org/10.31046/tl.v3i2.158

Senapatiratne, Timothy, “The Assemblies of God: A Bibliographic Essay,” 4:1 (2011), 91-95. https://doi. org/10.31046/tl.v4i1.171

-—-, “Oxford Encyclopedia of Biblical Interpretation,” 7:2 (2014), 62-63. https://doi.org/10.31046/tl.v7i2.333

---, Gundry, Jenifer and Trott, Garrett, “Citation Analysis and Its Potential In Theological Libraries,” 8:2 (2015), 16-21. https://doi.org/10.31046/tl.v8i2.389

Shaffett, John E., “The Praeger Handbook of Religion and Education in the United States,” 3:1 (2010), 64-66. https://doi.org/10.31046/tl.v3i1.127

---, "Staff Development on a Shoestring," 6:1 (2013), 90-91. https://doi.org/10.31046/tl.v6i1.241

Shepherd, William H., “The New Interpreter's Handbook of Preaching,” 2:2 (2009), 121-123. https://doi. org/10.31046/tl.v2i2.104

---, "Early Christian Apocrypha: A Bibliographic Essay," 3:1 (2010), 40-47. https://doi.org/10.31046/ tl.v3i1.125

Sheppard, Beth M., “The Art of the Bibliographic Essay,” 1:1 (2008), 46-48. https://doi.org/10.31046/tl.v1i1.29

---, “Diktuon: The Kindle 2 - Risk and Promise,” 2:2 (2009), 3-8. https://doi.org/10.31046/tl.v2i2.123

-_-, “E-Journals and the Seminary Library Context: A Response to Jeffrey Garrett,” 2:2 (2009), 43-46. https:// doi.org/10.31046/tl.v2i2.109

-—-, “Diktuon: A Good Look at the Nook,” 4:1 (2011), 3-7. https://doi.org/10.31046/tl.v4i1.173 
-_-, "Resources for the Study of the Classical World in the New Testament Era," 5:2 (2012), 67-74. https:// doi.org/10.31046/tl.v5i2.223

---, "By the Numbers: Bibliometrics and Altmetrics as Measures of Faculty Impact in the Field of Religion," 8:2 (2015), 28-36. https://doi.org/10.31046/tl.v8i2.357

---, "Theological Librarian vs. Machine: Taking on the Amazon Alexa Show (with Some Reflections on the Future of the Profession),” 10:1 (2017), 8-23. https://doi.org/10.31046/tl.v10i1.475

---, “Reading for Faith and Learning,” 10:1 (2017), 50-52. https://doi.org/10.31046/tl.v10i1.476

Shotts, D’Anna and Tarpley, Margaret, “Encyclopedia of African Religion,” 2:2 (2009), 124-126. https://doi. org/10.31046/tl.v2i2.102

Shrauner, Ryan Douglas, “The Religion and Theology Student Writer's Manual and Reader's Guide,” 12:1 (2019), 68-70. https://doi.org/10.31046/tl.v12i1.539

Siedlecki, Armin, “Westminster Dictionary of Theologians,” 1:2 (2008), 91-92. https://doi.org/10.31046/ tl.v1i2.42

Skinner, Michael, “The History of Western Philosophy of Religion,” 3:2 (2010), 69-71. https://doi.org/10.31046/ tl.v3i2.152

Skreslet, Paula Youngman, “Basic Primary Sources in Islamic Religion,” 1:1 (2008), 49-53. https://doi. org/10.31046/tl.v1i1.40

-_-, “The Princeton Encyclopedia of Islamic Political Thought,” 6:2 (2013), 83-85. https://doi.org/10.31046/ tl.v6i2.290

Skypeck, James R., “Web Review: Spirituality, Medicine and Health Bibliography,” 6:2 (2013), 7-8. https:// doi.org/10.31046/tl.v6i2.271

Smith, Daniel, “Inquiry and Research: A Relational Approach in the Classroom,” 12:1 (2019), 63-64. https:// doi.org/10.31046/tl.v12i1.538

Smith, Kevin L., “Open Access and Authors’ Rights Management: A Possibility for Theology?” 2:1 (2009), 45-56. https://doi.org/10.31046/tl.v2i1.73

Smith, Sean, "Small Change, Big Impact: Assessment and Creative Re-purposing of Underutilized Space at the BU Theology Library,” 12:1 (2019), 1-2. https://doi.org/10.31046/tl.v12i1.536

Snavely, Iren Light, “William Penn’s Experiment in Religious Freedom: Resources Documenting the Colonial Religious Experience at the State Library of Pennsylvania,” 1:2 (2008), 60-76. https://doi.org/10.31046/ tl.v1i2.48

Soule, Stephanie L. and Ewalt, Jillian, “The John Stokes and Mary’s Gardens Collection,” 9:2 (2016), $23-27$. https://doi.org/10.31046/tl.v9i2.439

Spina, Carli, “Libraries and Universal Design,” 10:1 (2017), 5-7. https://doi.org/10.31046/tl.v10i1.464

Spomer, Michelle Y., "The Fine Art of Throwing Sheep: How Facebook Can Contribute to Librarianship and Community in Theological Institutions," 1:1 (2008), 10-21. https://doi.org/10.31046/tl.v1i1.37

-_-, “Encyclopedia of Religious Revivals in America,” 1:1 (2008), 62-64. https://doi.org/10.31046/tl.v1i1.25

Stanley, Sarah, “Drawing on God: Theology in Graphic Novels,” 2:1 (2009), 83-88. https://doi.org/10.31046/ tl.v2i1.72

Stayer, Caren C., “The Encyclopedia of Eastern Orthodox Christianity,” 4:1 (2011), 112-113. https://doi. org/10.31046/tl.v4i1.186 
Steffel, Nick, “The Encyclopedia of Time: Science, Philosophy, Theology \& Culture,” 3:1 (2010), 67-68. https:// doi.org/10.31046/tl.v3i1.126

Stephens, Myka Kennedy, “The Future of the Small Theological Library,” 9:1 (2016), 28-32. https://doi. org/10.31046/tl.v9i1.411

Stern, Richard C., “Homiletics: A Bibliographic Essay,” 6:1 (2013), 69-77.https://doi.org/10.31046/tl.v6i1.262 Stevens, Kerrie, “Practical Tips for Facilitating Research,” 9:2 (2016), 37. https://doi.org/10.31046/tl.v9i2.443 Stewart, David R., “Editorial,” 4:1 (2011), iii. https://doi.org/10.31046/tl.v4i1.196

-—-, “'Oh, the Editor's Life is the Life for Me ...,” 6:1 (2013), iii. https://doi.org/10.31046/tl.v6i1.267

---, “Quinquennial' - Reflecting on TL’s Fifth Anniversary,” 6:2 (2013), iii. https://doi.org/10.31046/ tl.v6i2.306

-_-, “Novice Contributor Tells All,” 7:1 (2014), iii. https://doi.org/10.31046/tl.v7i1.330

-_-, “Open Access,” 7:1 (2014), 72-74. https://doi.org/10.31046/tl.v7i1.323

-_-, “Achieving Literary Liftoff,” 7:2 (2014), iii. https://doi.org/10.31046/tl.v7i2.341

-_-, “In Search of a 'Culture of Writing,”, 8:1 (2015), iii. https://doi.org/10.31046/tl.v8i1.375

-—-, “Changes Afoot,” 8:2 (2015), iii. https://doi.org/10.31046/tl.v8i2.394

-—-, "Editor's Adios,” 9:1 (2016), iii. https://doi.org/10.31046/tl.v9i1.416 and Crown, Ronald W., “Why Theological Librarianship?” 1:1 (2008), 4. https://doi.org/10.31046/tl.v1i1.35

-_- and Crown, Ronald W., “Our Second Issue,” 1:2 (2008), 3. https://doi.org/10.31046/tl.v1i2.65

-_- and Crown, Ronald W., “Two Years On,” 2:2 (2009), iii. https://doi.org/10.31046/tl.v2i2.124

--- and Crown, Ronald W., "Change, Challenge, Opportunity - a Forum on Electronic Journals,” 2:2 (2009), 36. https://doi.org/10.31046/tl.v2i2.122

--- and Crown, Ronald W., “Why Write?” 3:1 (2010), iii. https://doi.org/10.31046/tl.v3i1.147

--- and Crown, Ronald W., "From the Co-Editors," 3:2 (2010), iii. https://doi.org/10.31046/tl.v3i2.170

--- and Crown, Ronald W., “Authors on Authoring,” 5:1 (2012), iii. https://doi.org/10.31046/tl.v5i1.219

-_- and Crown, Ronald W., "Introduction: The Reshaping of Libraries,” 5:1 (2012), 8. https://doi.org/10.31046/ $\underline{\text { tl.v5i1.220 }}$

-_-, Butler, Rebecca, Pakala, James C., Darlack, James Marion, Day, Donald E., Kroll, Anna Lois, Amodeo, Anthony, Engelson, Leslie A., “Special Forum: Best Professional Development Experiences, Spring 2014,” 7:2 (2014), 26-30. https://doi.org/10.31046/tl.v7i2.344

Studzinski, Raymond James, “Bible Reading Revisited: The Librarian's Guide to Lectio Divina and Formative Styles of Reading,” 7:1 (2014), 56-64. https://doi.org/10.31046/tl.v7i1.327

Stuehrenberg, Paul, “Theological Libraries and International Collaboration in Southeast Asia,” 4:1 (2011), 32-40. https://doi.org/10.31046/tl.v4i1.194

-_-, “Telling the Library's Story: A Personal Reflection,” 5:2 (2012), 39-42.https://doi.org/10.31046/tl.v5i2.235

Stutzman, Karl, “Diktuon: Link Resolvers for Theological Libraries,” 6:1 (2013), 1-3. https://doi.org/10.31046/ tl.v6i1.257

Swanson, Dennis M., “Oxford Dictionary of the Bible and Archaeology,” 7:1 (2014), 75-76. https://doi. org/10.31046/tl.v7i1.322 
Tait, Jennifer Woodruff, “More Technology for the Rest of Us,” 3:2 (2010), 72-73. https://doi.org/10.31046/ tl.v3i2.168

-_-, “Tales of an Editor,” 9:1 (2016), 33-37. https://doi.org/10.31046/tl.v9i1.412

---, “Editorial Board Introductions,” 10:1 (2017), iii. https://doi.org/10.31046/tl.v10i1.469

---, “Theological Librarianship Talks Open Access,” 10:1 (2017), 24. https://doi.org/10.31046/tl.v10i1.477

-—-, “We're All Librarians Now?” 11:1 (2018), iii. https://doi.org/10.31046/tl.v11i1.509

_-_, "Theologians and Philosophers Using Social Media: Advice, Tips, and Testimonials,” 11:1 (2018), 60. https://doi.org/10.31046/tl.v11i1.510

---, “Theological Librarianship at 10: A Long Look Back, a Long Look Forward,” 11:2 (2018), iii-viii. https:// doi.org/10.31046/tl.v11i2.526

-_-, “Theological Libraries in Prison: A Special Forum,” 11:2 (2018), 12. https://doi.org/10.31046/tl.v11i2.532

Tan, Felipe E. and Robertson, Terry Dwain, "An Evaluation of the Classification Scheme for Adventists and Ellen White,” 11:1 (2018), 28-36. https://doi.org/10.31046/tl.v11i1.473

Tarpley, Margaret, “Encyclopedia of Pentecostal and Charismatic Christianity,” 1:1 (2008), 71-72. https://doi. org/10.31046/tl.v1i1.18

Tarpley, Margaret and Shotts, D’Anna, “Encyclopedia of African Religion,” 2:2 (2009), 124-126. https://doi. org/10.31046/tl.v2i2.102

Taylor, Sharon A., "Supporting Digital Humanities for Knowledge Acquisition in Modern Libraries,” 9:2 (2016), 38-39. https://doi.org/10.31046/tl.v9i2.429

---, Hook, William J. and Myers, Sara J., “Effective Leadership in Tough Times: Three Essays,” 2:1 (2009), 20-34. https://doi.org/10.31046/tl.v2i1.92

Teasdale, Mark R., “Growth or Declension: Methodist Historians' Treatment of the Relationship Between the Methodist Episcopal Church and the Culture of the United States,” 3:2 (2010), 34-44. https://doi. org/10.31046/tl.v3i2.163

Thompson, John W., "The Best Cataloger is a Frustrated Library User: Cataloging Failure and the Underutilization of Library Resources," 8:2 (2015), 22-27. https://doi.org/10.31046/tl.v8i2.401

Tinerella, Vincent P., “Secret Sisters: Women Religious under European Communism Collection at the Catholic Theological Union,” 3:2 (2010), 8-15. https://doi.org/10.31046/tl.v3i2.154

Trott, Garrett, “The Blackwell Companion to the Theologians,” 2:2 (2009), 127-129. https://doi.org/10.31046/ tl.v2i2.98

_-_, “The Corban University Library,” 5:1 (2012), 23-25. https://doi.org/10.31046/tl.v5i1.211

-_-, "Handbook for the Study of the Historical Jesus,” 5:1 (2012), 94-95. https://doi.org/10.31046/tl.v5i1.190

---, “The Routledge Companion to the Practice of Christian Theology,” 9:2 (2016), 40-41. https://doi. org/10.31046/tl.v9i2.449

---, Gundry, Jenifer and Senapatiratne, Timothy, “Citation Analysis and Its Potential In Theological Libraries,” 8:2 (2015), 16-21. https://doi.org/10.31046/tl.v8i2.389

Truman, Gerald, “From the Ground Up: Starting a Theological Library from Scratch,” 3:1 (2010), 23-26. https://doi.org/10.31046/tl.v3i1.133 
Turner, Bob, “Dictionary of the Bible and Western Culture," 7:1 (2014), 77-78. https://doi.org/10.31046/ tl.v7i1.311

-_-, “IATG3: Internationales Abkürzungsverzeichnis für Theologie und Grenzgebiete,” 9:1 (2016), 61. https:// doi.org/10.31046/tl.v9i1.414

Ulrich, Jennifer, “Web Review: Global Anabaptist Mennonite Encyclopedia Online (GAMEO),” 7:1 (2014), 6-7. https://doi.org/10.31046/tl.v7i1.317

-_-, “The Bloomsbury Guide to Pastoral Care,” 8:1 (2015), 89-90. https://doi.org/10.31046/tl.v8i1.377

Van Dyk, Gerrit, “Finding Religion: An Analysis of Theology LibGuides,” 8:2 (2015), 37-45. https://doi. org/10.31046/tl.v8i2.384

---, “Understanding Mormonism: Foundational Sources on its Culture, History, and Theology,” 12:1 (2019), 50-60. https://doi.org/10.31046/tl.v12i1.531

Veldheer, Kris, “Encyclopedia of New Religious Movements,” 1:1 (2008), 60-61. https://doi.org/10.31046/ tl.v1i1.30

Vergel, Alfredo, “Using Technology for Ministry: Trends, Principles and Applications,” 3:2 (2010), 16-21. https://doi.org/10.31046/tl.v3i2.128

Vorp, Donald M., “Web Reviews: Online Critical Pseudepigrapha and Online Medieval Sources Bibliography," 1:1 (2008), 8-9. https://doi.org/10.31046/tl.v1i1.21

Wason, Brandon C., "Five Recent Commentaries on Acts," 8:1 (2015), 70-76.https://doi.org/10.31046/tl.v8i1.364

-_-, “The Routledge Companion to Religion and Popular Culture,” 9:2 (2016), 42-43. https://doi.org/10.31046/ tl.v9i2.432

Weaver, John B., “Narratives of Reading in Luke-Acts,” 1:1 (2008), 22-37. https://doi.org/10.31046/tl.v1i1.27

-_-, “Theological Libraries and 'The Next Christendom': Connecting North American Theological Education to Uses of the Book in the Global South,” 1:2 (2008), 38-48. https://doi.org/10.31046/tl.v1i2.45

Webb, Lee, “Voices of Early Christianity: Documents from the Origins of Christianity,” 7:1 (2014), 79-80. https://doi.org/10.31046/tl.v7i1.318

Weiss, Nicholas, “Brill's Encyclopedia of Hinduism,” 6:1 (2013), 92-93. https://doi.org/10.31046/tl.v6i1.268 Wenderoth, Christine, “In a Parallel Universe? A Response to Jeffrey Garrett,” 2:2 (2009), 47-50. https://doi. org/10.31046/tl.v2i2.96

- - , "Now You See It: How the Brain Science of Attention Will Transform the Way We Live, Work, and Learn," 5:2 (2012), 99-100. https://doi.org/10.31046/tl.v5i2.236

Whitford, Philip, "An Index to English Periodical Literature on the Old Testament and Ancient Near Eastern Studies: Volume IX," 6:1 (2013), 94-95. https://doi.org/10.31046/tl.v6i1.260

Wigner, Dann, “Librarianship as a Spiritual Practice,” 10:1 (2017), 2-4. https://doi.org/10.31046/tl.v10i1.455 Williams, Audrey, “The John Richard Allison Library, Regent College,” 5:1 (2012), 26-29. https://doi. org/10.31046/tl.v5i1.217

Willis, Tamie and Rosser, Christopher Michael, "Flip Over Research Instruction: Delivery, Assessment, and Feedback Strategies for “Flipped' Library,” 9:1 (2016), 22-27. https://doi.org/10.31046/tl.v9i1.413

Willkom, Renee Catherine, “An Introductory Dictionary of Theology and Religious Studies,” 2:1 (2009), 110-112. https://doi.org/10.31046/tl.v2i1.71 
Wiseman, Christine, Jackson, Andrea and Ost, Brad, "Funding the Future of African American Religion Archival Collections,” 9:1 (2016), 16-21. https://doi.org/10.31046/tl.v9i1.409

Wiser, James, “'Playing Well With Others': New Opportunities for Library Consortia,” 5:2 (2012), 43-47. https:// doi.org/10.31046/tl.v5i2.237

Woodward, Michael, “Dictionary of Biblical Criticism and Interpretation,” 2:1 (2009), 113-114. https://doi. org/10.31046/tl.v2i1.74

Wright, Logan S., “Religion Past and Present,” 1:2 (2008), 93-95. https://doi.org/10.31046/tl.v1i2.46

Young, Kathryn A., “The Catholic Church Extension Society Records at Loyola University Chicago,” 9:2 (2016), 28-29. https://doi.org/10.31046/tl.v9i2.440

\section{INDEX OF SECTIONS}

\section{Bibliographic Essays}

“Action Research for Theological Librarians,” Hamilton, Barry W., 1:1 (2008), 54-59. https://doi.org/10.31046/ tl.v1i1.19

“The Art of the Bibliographic Essay,” Sheppard, Beth M., 1:1 (2008), 46-48. https://doi.org/10.31046/tl.v1i1.29

“The Assemblies of God: A Bibliographic Essay," Senapatiratne, Timothy, 4:1 (2011), 91-95. https://doi. org/10.31046/tl.v4i1.171

“Basic Primary Sources in Islamic Religion,” Skreslet, Paula Youngman, 1:1 (2008), 49-53. https://doi. org/10.31046/tl.v1i1.40

“The Bible and Handel's Messiah: Some Sources on Their Relation and Use,” Powell, David R., 2:2 (2009), 94-97. https://doi.org/10.31046/tl.v2i2.121

"Bible Reading Revisited: The Librarian's Guide to Lectio Divina and Formative Styles of Reading," Studzinski, Raymond James, 7:1 (2014), 56-64. https://doi.org/10.31046/tl.v7i1.327

“Bibliographic Essay: Augustine of Hippo,” Fitzgerald, Allan, 8:2 (2015), 46-55. https://doi.org/10.31046/ tl.v8i2.383

“Christian Traditions in the Contemporary Middle East,” Baker, Matthew, 4:1 (2011), 68-74. https://doi. org/10.31046/tl.v4i1.172

“The Cinematic Savior: Jesus Films and Related Literature,” Rainey, Jon, 3:2 (2010), 27-33. https://doi. org/10.31046/tl.v3i2.157

“Considerations in Preparing a Biblical Bibliography: Case Study: The Scroll of Esther," Lubetski, Edith and Lubetski, Meir, 3:1 (2010), 31-39. https://doi.org/10.31046/tl.v3i1.129

“Drawing on God: Theology in Graphic Novels," Stanley, Sarah, 2:1 (2009), 83-88. https://doi.org/10.31046/ tl.v2i1.72

“Early Christian Apocrypha: A Bibliographic Essay,” Shepherd, William H., 3:1 (2010), 40-47. https://doi. org/10.31046/tl.v3i1.125

“Ephrem the Syrian: A Syriac Poet in Armenian Verse,” Mathews, Edward George, 5:1 (2012), 71-76. https:// doi.org/10.31046/tl.v5i1.205

“Father Charles E. Coughlin - the ‘Radio Priest’ of the 1930s,” Ketchaver, Karen G., 2:2 (2009), 81-88. https:// doi.org/10.31046/tl.v2i2.112 
“Five Recent Commentaries on Acts,” Wason, Brandon C., 8:1 (2015), 70-76. https://doi.org/10.31046/tl.v8i1.364

"Framing Books and Reading: An Exploration of Sixteenth Century Title Borders," Graham, M. Patrick, 6:2 (2013), 53-62. https://doi.org/10.31046/tl.v6i2.291

“Going a Step Beyond-Websites with More than Just Bibles,” Kuykendall, Michael, 3:2 (2010), 22-26. https:// doi.org/10.31046/tl.v3i2.159

“Growth or Declension: Methodist Historians' Treatment of the Relationship Between the Methodist Episcopal Church and the Culture of the United States," Teasdale, Mark R., 3:2 (2010), 34-44. https://doi.org/10.31046/ tl.v3i2.163

“Homiletics: A Bibliographic Essay,” Stern, Richard C., 6:1 (2013), 69-77.https://doi.org/10.31046/tl.v6i1.262

"Influence of the Fathers of the Church on Recent Catholic Conversion Narratives," Kiczek, Steven Allen, 5:1 (2012), 56-66. https://doi.org/10.31046/tl.v5i1.197

"Information Behaviour(s) of Theologians: A Literature Review,” Penner, Katharina, 2:1 (2009), 67-82. https:// doi.org/10.31046/tl.v2i1.79

“Inner-Biblical Allusion,” Lester, G Brooke, 2:2 (2009), 89-93. https://doi.org/10.31046/tl.v2i2.110

“Klostersturm and Secularization in Central Europe: What Happened to the Libraries?" Garrett, Jeffrey, 8:1 (2015), 61-69. https://doi.org/10.31046/tl.v8i1.372

“The Librarian's Guide to the Apostolic Fathers,” Jefford, Clayton N., 5:2 (2012), 59-66. https://doi.org/10.31046/ tl.v5i2.224

“The Literature of Ecclesiology: A Ten Year Retrospective,” Guyette, Fred, 4:1 (2011), 75-90. https://doi. org/10.31046/tl.v4i1.146

“Open Access Liturgical Resources for Judaism,” Nosek, Jason D., 6:2 (2013), 63-66. https://doi.org/10.31046/ tl.v6i2.265

“Participatory Cultures and Implications for Theological Education,” Crowley, Eileen D, 6:1 (2013), 60-68. https://doi.org/10.31046/tl.v6i1.251

“Pope Francis’ Strong Thought,” Lemna, Keith Edward, 7:2 (2014), 45-53. https://doi.org/10.31046/tl.v7i2.343

"Resources for the Study of the Classical World in the New Testament Era," Sheppard, Beth M., 5:2 (2012), 67-74. https://doi.org/10.31046/tl.v5i2.223

“Ronald Knox: A Bibliographic Essay,” Chappel, James, 1:2 (2008), 49-53. https://doi.org/10.31046/tl.v1i2.44

“Six Segments on Military Ministry,” Knapp, Kathryn, 3:1 (2010), 27-30. https://doi.org/10.31046/tl.v3i1.134

“Teaching the History of the Bible as Book,” Eldevik, Bruce Eugene, 9:1 (2016), 38-44. https://doi.org/10.31046/ tl.v9i1.427

“The Theological Librarian's Role in Fundraising,” Kemmis, Barbara, 2:1 (2009), 57-66. https://doi. org/10.31046/tl.v2i1.77

“Thomas Merton: American Monk, Artist and Social Critic,” Belcastro, David Joseph, 7:2 (2014), 31-44. https:// doi.org/10.31046/tl.v7i2.334

“William Penn's Experiment in Religious Freedom: Resources Documenting the Colonial Religious Experience at the State Library of Pennsylvania," Snavely, Iren Light, 1:2 (2008), 60-76. https://doi.org/10.31046/ tl.v1i2.48

“The Work of Evelyn Fox Keller as a Resource for Study in Science and Religion,” Kordesh, Kathleen, 1:2 (2008), 54-59. https://doi.org/10.31046/tl.v1i2.56 
"Wrestling Long into the Night: Sources on the Mainline Protestant Denominations' Debate about Homosexuality,” Burnam, Paul D., 6:1 (2013), 47-59. https://doi.org/10.31046/tl.v6i1.249

“Zen Garden and No Zen Garden: A Bibliographic Essay,” Masuchika, Glenn Norio, 5:1 (2012), 67-70. https:// doi.org/10.31046/tl.v5i1.204

\section{Columns}

“Diktuon: A Good Look at the Nook," Sheppard, Beth M., 4:1 (2011), 3-7. https://doi.org/10.31046/tl.v4i1.173

“Diktuon: Bibliographic Managers,” Keck, Andrew J., 1:2 (2008), 4-5. https://doi.org/10.31046/tl.v1i2.62

“Diktuon: Digital Repositories and Theological Libraries,” Keck, Andrew J., 1:1 (2008), 6-7. https://doi. org/10.31046/tl.v1i1.17

“Diktuon: Drupal - CMS and Beyond,” Darlack, James Marion, 6:2 (2013), 1-3. https://doi.org/10.31046/ tl.v6i2.304

“Diktuon: Finding e-books,” Keck, Andrew J., 3:1 (2010), 1-3. https://doi.org/10.31046/tl.v3i1.143

"Diktuon: Getting Involved With the Digital Humanities in Theology, Biblical Studies, and Religious Studies," Gerber, Kent T. K., 9:1 (2016), 5-10. https://doi.org/10.31046/tl.v9i1.420

“Diktuon: Link Resolvers for Theological Libraries,” Stutzman, Karl, 6:1 (2013), 1-3. https://doi.org/10.31046/ tl.v6i1.257

“Diktuon: Mobile Devices and Libraries,” Keck, Andrew J., 5:1 (2012), 1-3. https://doi.org/10.31046/tl.v5i1.221

"Diktuon: Providing Library Services in the Cloud: New Benefits Realized, New Skills Required," Hartman, Robin R., 7:2 (2014), 6-8. https://doi.org/10.31046/tl.v7i2.348

“Diktuon: Purchasing at the Point of Need: An Acquisitions Pilot Project,” Deeds, Leland, 7:1 (2014), 1-2. https://doi.org/10.31046/tl.v7i1.315

“Diktuon: Tech Training for a New Age,” Bartholomew, Jennifer K., 3:2 (2010), 1-3. https://doi.org/10.31046/ tl.v3i2.160

“Diktuon: The Framework for Information Literacy and Theological Education,” Badke, William, 8:2 (2015), 4-7. https://doi.org/10.31046/tl.v8i2.385

“Diktuon: The Kindle 2 - Risk and Promise,” Sheppard, Beth M., 2:2 (2009), 3-8. https://doi.org/10.31046/ tl.v2i2.123

“Diktuon: The Library as Publisher? Is It Possible for a Small Library?” McMahon, Melody Layton, 8:1 (2015), 4-6. https://doi.org/10.31046/tl.v8i1.365

“Diktuon: Virtual Reference,” Keck, Andrew J., 2:1 (2009), 1-2. https://doi.org/10.31046/tl.v2i1.83

“Diktuon: Web-based Statistics Trackers,” Rozear, Hannah, 5:2 (2012), 1-3.https://doi.org/10.31046/tl.v5i2.245

“Featured Web Resource: Theological Commons,” Murray, Gregory P., 9:2 (2016), 1-4. https://doi.org/10.31046/ tl.v9i2.434

“Finding Time to Write,” Elder, Jane Lenz, 10:1 (2017), 1. https://doi.org/10.31046/tl.v10i1.471

“Information Literacy: A Theological Librarian Reflects on Writers and Writing," Phillips, Robert, 3:1 (2010), 4-5. https://doi.org/10.31046/tl.v3i1.144

"Information Literacy: Adaptability and Authenticity-Using the Next Generation's Powers for Good, Not Evil," Norris, Tiffany Davis, 2:2 (2009), 1-2. https://doi.org/10.31046/tl.v2i2.106 
“Information Literacy: More to Learn-and Teach!” Phillips, Robert, 2:1 (2009), 3-4. https://doi.org/10.31046/ tl.v2i1.84

“Information Literacy: Writing Based Research,” Phillips, Robert, 3:2 (2010), 4-5. https://doi.org/10.31046/ tl.v3i2.164

"Introducing the Open Access Digital Theological Library (OADTL): Creating the World's First Entirely Open Access Library in Religious Studies," Phillips, Thomas E., Baker, Drew and Hidalgo, Ann, 11:2 (2018), 1-3. https://doi.org/10.31046/tl.v11i2.520

“Profiles: Doralyn Joanne Hickey, 1929-1987: An Appreciation,” Loyd, Roger, 6:1 (2013), 4-6. https://doi. org/10.31046/tl.v6i1.256

“Profiles: A Giant in the Land: H. Lucille Hager, 1924-2004,” Eberts, Susan, 8:1 (2015), 1-3. https://doi. org/10.31046/tl.v8i1.373

“Profiles: A Pilgrim's Progress: Decherd Turner, 1922-2002," Hotchkiss, Valeri, 7:1 (2014), 3-5. https://doi. org/10.31046/tl.v7i1.326

"Profiles: Aspiring Vision and Attention to Detail: Kenneth Sperber Gapp (1905-1966)," Dearborn, Virginia E and Henke, Kenneth W, 8:2 (2015), 1-3. https://doi.org/10.31046/tl.v8i2.396

“Profiles: Bibliographer Extraordinaire: Peter De Klerk, 1927-1997,” Schemper, Lugene L., 7:2 (2014), 1-3. https://doi.org/10.31046/tl.v7i2.345

“Profiles: Father Oliver Kapsner, OSB (1902-1991) - A Life in Libraries,” Heintzelman, Matthew, 5:1 (2012), 4-6. https://doi.org/10.31046/tl.v5i1.216

“Profiles: Fr. Simeon Daly, OSB,” McMahon, Melody Layton, 9:1 (2016), 1-4. https://doi.org/10.31046/tl.v9i1.415

“Profiles: John Albert Bollier, 1927-2010,” Estelle-Holmer, Suzanne M., 6:2 (2013), 4-6. https://doi. org/10.31046/tl.v6i2.305

“Profiles: Quiet Person, Powerfully Loud Influence: Norris Magnuson (1932-2006)," Oslund, Sandra, 9:2 (2016), 9-11. https://doi.org/10.31046/tl.v9i2.433

“Web Review: Global Anabaptist Mennonite Encyclopedia Online (GAMEO),” Ulrich, Jennifer, 7:1 (2014), 6-7. https://doi.org/10.31046/tl.v7i1.317

“Web Review: Hymnary.org - Comprehensive Index of Hymns and Hymnals,” Mayo, David, 5:2 (2012), 4-5. https://doi.org/10.31046/tl.v5i2.233

"Web Review: Online Resources for the Study of Chinese Religion and Philosophy," Adkins, Martha, 9:2 (2016), 5-8. https://doi.org/10.31046/tl.v9i2.435

“Web Review: Perseus Digital Library,” Darlack, James Marion, 9:1 (2016), 11-15. https://doi.org/10.31046/ tl.v9i1.423

“Web Review: Spirituality, Medicine and Health Bibliography,” Skypeck, James R., 6:2 (2013), 7-8. https:// doi.org/10.31046/tl.v6i2.271

“Web Review: The Association of Religion Data Archives," Murrain, Shanee Yvette, 7:2 (2014), 4-5. https:// doi.org/10.31046/tl.v7i2.336

“Web Review: The Jonathan Edwards Center at Yale University,” Miller, Rebecca Louise, 5:1 (2012), 7. https:// doi.org/10.31046/tl.v5i1.206

“Web Review: The Pew Forum on Religion \& Public Life,” Burr, Trisha A., 6:1 (2013), 7-8. https://doi. org/10.31046/tl.v6i1.258 
"Web Review: Working Virtually on the Text and Manuscripts Behind the Document: Doing New Testament Textual Criticism on the Web,” Phillips, Thomas E. and Bilby, Mark Glen, 8:1 (2015), 7-9. https://doi. org/10.31046/tl.v8i1.374

"Web Review: Working Virtually on the Texts and Manuscripts Behind the Document, II: Doing Jewish Bible/ Old Testament Textual Criticism on the Web," Phillips, Thomas E. and Baker, Drew, 8:2 (2015), 8-10. https:// doi.org/10.31046/tl.v8i2.393

“Web Reviews: Counterbalance,” Limpitlaw, Amy, 2:1 (2009), 5-7. https://doi.org/10.31046/tl.v2i1.82

“Web Reviews: ETANA,” Estelle-Holmer, Suzanne M., 1:2 (2008), 6. https://doi.org/10.31046/tl.v1i2.64

“Web Reviews: Monachos.net-Orthodoxy Through Patristic, Monastic, and Liturgical Study,” Schwab, Juliet Crawford, 3:2 (2010), 6-7. https://doi.org/10.31046/tl.v3i2.158

“Web Reviews: Online Critical Pseudepigrapha and Online Medieval Sources Bibliography,” Vorp, Donald M., 1:1 (2008), 8-9. https://doi.org/10.31046/tl.v1i1.21

“Web Reviews: Religious Institute-Denominational Statements,” Durham, Erica, 4:1 (2011), 1-2. https://doi. org/10.31046/tl.v4i1.191

"Web Reviews: The Gifford Lectures-Over 100 Years of Renowned Lectures on Natural Theology," Limpitlaw, Amy, 3:1 (2010), 6. https://doi.org/10.31046/tl.v3i1.140

“Web Reviews: Theological Perspectives of the Reformation,” Limpitlaw, Amy, 2:2 (2009), 9-10. https://doi. org/10.31046/tl.v2i2.116

\section{Critical Reviews}

“Academic Libraries and Toxic Leadership,” Adams, Richard Manly, Jr., 10:1 (2017), 43-44. https://doi. org/10.31046/tl.v10i1.466

“America’s Public Bible,” DeBoer, Jacob A., 11:1 (2018), 53-54. https://doi.org/10.31046/tl.v11i1.505

“Ancient Christian Doctrine,” Parker, T. R., 2:2 (2009), 115-117. https://doi.org/10.31046/tl.v2i2.105

“The Annotated Luther, Volume I: The Roots of Reform,” Cox, David E., 9:2 (2016), 30. https://doi.org/10.31046/ tl.v9i2.450

“Apps for Librarians,” Gonzalez, Lisa, 8:2 (2015), 61-62. https://doi.org/10.31046/tl.v8i2.403

"Archives in Libraries: What Librarians and Archivists Need to Know to Work Together," Anderson, Christopher .J, 11:2 (2018), 40-41. https://doi.org/10.31046/tl.v11i2.525

“Atlas of Global Christianity,” Friede, Eric, 3:1 (2010), 53-56. https://doi.org/10.31046/tl.v3i1.137

“Australasian Religion Index (ARI),” Kolb, Daniel, 1:2 (2008), 88. https://doi.org/10.31046/tl.v1i2.54

“The Baker Illustrated Bible Dictionary,” Darlack, James Marion, 7:1 (2014), 68-69. https://doi.org/10.31046/ tl.v7i1.319

“The Bible in Music: A Dictionary of Songs, Works, and More,” Schroeder, Joy, 9:2 (2016), 35-36. https://doi. org/10.31046/tl.v9i2.428

“A Biblical Hebrew Reference Grammar,” Goodwin, Shawn Virgil, 12:1 (2019), 65-67. https://doi.org/10.31046/ tl.v12i1.541

“The Blackwell Companion to the Theologians,” Trott, Garrett, 2:2 (2009), 127-129. https://doi.org/10.31046/ tl.v2i2.98 
“The Bloomsbury Guide to Pastoral Care,” Ulrich, Jennifer, 8:1 (2015), 89-90. https://doi.org/10.31046/ tl.v8i1.377

“The Book of Revelation and Its Interpreters: Short Studies and an Annotated Bibliography,” Adkins, Martha, 11:2 (2018), 38-39. https://doi.org/10.31046/tl.v11i2.522

“Brill's Encyclopedia of Hinduism,” Weiss, Nicholas, 6:1 (2013), 92-93. https://doi.org/10.31046/tl.v6i1.268

“The Cambridge Dictionary of Christian Theology,” Phillips, Robert, 6:1 (2013), 88-89. https://doi.org/10.31046/ tl.v6i1.252

“The Cambridge Dictionary of Judaism \& Jewish Culture,” Anderson, David, 6:1 (2013), 78-79. https://doi. org/10.31046/tl.v6i1.269

“The Canterbury Dictionary of Hymnology,” McMahon, Melody Layton, 8:1 (2015), 85-86. https://doi. org/10.31046/tl.v8i1.356

“Christian Catechetical Texts,” Mitchell, Michael R., 5:2 (2012), 92-94. https://doi.org/10.31046/tl.v5i2.243

“Christian Theology: the Classics,” McMullen, Kenneth, 8:2 (2015), 69-70. https://doi.org/10.31046/tl.v8i2.404

"Church History: An Introduction to Research Methods and Resources," Estes, James Andrew, 11:1 (2018), 55-57. https://doi.org/10.31046/tl.v11i1.504

“Church-State Issues in America Today,” Ellis, Teresa Cardin, 1:2 (2008), 83-85. https://doi.org/10.31046/ $\underline{\text { tl.v1i2.53 }}$

“Comparative Review of Three Bible Atlases,” Litwak, Kenneth D., 3:2 (2010), 63-66. https://doi.org/10.31046/ tl.v3i2.165

"A Compendium of Musical Instruments and Instrumental Terminology in the Bible," Campbell, Donna R., 3:2 (2010), 48-50. https://doi.org/10.31046/tl.v3i2.151

“Concise American Catholic Encyclopedia,” Hayes, Elyse, 6:1 (2013), 83-85. https://doi.org/10.31046/tl.v6i1.261

“Crash Course in Library Services to People with Disabilities,” Litwak, Kenneth D., 7:2 (2014), 60-61. https:// doi.org/10.31046/tl.v7i2.328

“Crossroads of War,” Grafton, Karla Fackler, 8:2 (2015), 63-64. https://doi.org/10.31046/tl.v8i2.392

“Cruising the Library: Perversities in the Organization of Knowledge,” Hughes, Barnaby, 10:1 (2017), 46-47. https://doi.org/10.31046/tl.v10i1.470

“Diccionario de Pensadores Cristianos,” Guzman, Alvaro Perez, 5:1 (2012), 81-82. https://doi.org/10.31046/ tl.v5i1.212

“Dictionary of Biblical Criticism and Interpretation,” Woodward, Michael, 2:1 (2009), 113-114. https://doi. org/10.31046/tl.v2i1.74

“Dictionary of Christian Spirituality,” Kokolus, Cait C., 5:2 (2012), 90-91. https://doi.org/10.31046/tl.v5i2.226

“Dictionary of Major Biblical Interpreters,” Powell, David R., 1:1 (2008), 65-67. https://doi.org/10.31046/ tl.v1i1.28

“Dictionary of Scripture and Ethics,” Baker, Matthew, 5:2 (2012), 75-77. https://doi.org/10.31046/tl.v5i2.229

“Dictionary of the Bible and Western Culture,” Turner, Bob, 7:1 (2014), 77-78. https://doi.org/10.31046/ tl.v7i1.311

“Dictionary of the Old Testament: Prophets,” Evans, Justin J, 7:2 (2014), 58-59. https://doi.org/10.31046/ tl.v7i2.321 
“Dictionary of Theologians to 1308,” Bales, John Glenn, 5:2 (2012), 78-79. https://doi.org/10.31046/tl.v5i2.230

"Doing Theological Research: An Introductory Guide for Survival in Theological Education," Grafton, Karla Fackler, 4:1 (2011), 101-102. https://doi.org/10.31046/tl.v4i1.179

“E-Book Collections,” Gonzalez, Lisa, 3:1 (2010), 57. https://doi.org/10.31046/tl.v3i1.136

“Eerdmans Dictionary of Early Judaism,” Grafton, Karla Fackler, 4:1 (2011), 103-104. https://doi.org/10.31046/ tl.v4i1.184

“Encyclopaedia Islamica,” Estelle-Holmer, Suzanne M., 2:2 (2009), 103-104. https://doi.org/10.31046/ tl.v2i2.119

“Encyclopedia of African Religion,” Tarpley, Margaret and Shotts, D’Anna, 2:2 (2009), 124-126. https://doi. org/10.31046/tl.v2i2.102

“Encyclopedia of Buddhism,” Pesch, Christine, 2:1 (2009), 104-105. https://doi.org/10.31046/tl.v2i1.63

“The Encyclopedia of Caribbean Religions,” Dittrich, Nicole C., 7:2 (2014), 56-57. https://doi.org/10.31046/ tl.v7i2.329

"Encyclopedia of Catholic Social Thought, Social Science, and Social Policy,” McIntosh-Doty, Mikail, 1:1 (2008), 68-70. https://doi.org/10.31046/tl.v1i1.20

“The Encyclopedia of Christian Civilization,” Garrett, J. Michael, 5:2 (2012), 82-84. https://doi.org/10.31046/ tl.v5i2.231

“The Encyclopedia of Christian Literature,” Keeney, Donald, 3:2 (2010), 60-62. https://doi.org/10.31046/ tl.v3i2.155

“Encyclopedia of Contemporary Christian Music: Pop, Rock, and Worship,” Schroeder, Joy, 3:1 (2010), 62-63. https://doi.org/10.31046/tl.v3i1.130

“Encyclopedia of Death \& the Human Experience,” Ost, Brad, 3:1 (2010), 60-61. https://doi.org/10.31046/ tl.v3i1.132

“Encyclopedia of Demons in World Religions and Cultures,” Day, Donald E., 5:2 (2012), 80-81. https://doi. org/10.31046/tl.v5i2.227

“The Encyclopedia of Eastern Orthodox Christianity,” Stayer, Caren C., 4:1 (2011), 112-113. https://doi. org/10.31046/tl.v4i1.186

“Encyclopedia of English Language Bible Versions,” McMullen, Kenneth, 6:2 (2013), 71-73. https://doi. org/10.31046/tl.v6i2.283

“Encyclopedia of Gender and Society,” Klemme, Rebecca, 4:1 (2011), 107-109. https://doi.org/10.31046/ tl.v4i1.169

“Encyclopedia of Hinduism,” Pesch, Christine, 2:1 (2009), 106-107. https://doi.org/10.31046/tl.v2i1.87

“Encyclopedia of Human Rights,” Boyd, Evan E., 3:1 (2010), 51-52. https://doi.org/10.31046/tl.v3i1.141

“The Encyclopedia of Jews in the Islamic World,” Marcus, Sara, 3:2 (2010), 67-68. https://doi.org/10.31046/ tl.v3i2.166

“Encyclopedia of Love in World Religions,” Jones, Jonathan, 2:1 (2009), 101-103. https://doi.org/10.31046/ tl.v2i1.81

“Encyclopedia of Missions and Missionaries,” Eldevik, Bruce Eugene, 1:2 (2008), 80-82. https://doi. org/10.31046/tl.v1i2.50 
“Encyclopedia of New Religious Movements,” Veldheer, Kris, 1:1 (2008), 60-61. https://doi.org/10.31046/ tl.v1i1.30

“Encyclopedia of Pentecostal and Charismatic Christianity,” Tarpley, Margaret, 1:1 (2008), 71-72. https://doi. org/10.31046/tl.v1i1.18

“Encyclopedia of Philosophers on Religion,” Jaeger, John David, 2:1 (2009), 98-100. https://doi.org/10.31046/ tl.v2i1.80

“Encyclopedia of Psychology and Religion,” Hanson, Mark, 3:2 (2010), 57-59. https://doi.org/10.31046/ tl.v3i2.167

“Encyclopedia of Religion and Film,” Gonzalez, Lisa, 6:1 (2013), 80-82. https://doi.org/10.31046/tl.v6i1.263

“Encyclopedia of Religion in America,” Bohanan, Adam S., 4:1 (2011), 98-100. https://doi.org/10.31046/ tl.v4i1.174

“Encyclopedia of Religious and Spiritual Development,” Kokolus, Cait C., 1:2 (2008), 86-87. https://doi. org/10.31046/tl.v1i2.43

“Encyclopedia of Religious Revivals in America,” Spomer, Michelle Y., 1:1 (2008), 62-64. https://doi. org/10.31046/tl.v1i1.25

“Encyclopedia of Taoism,” Pesch, Christine, 2:1 (2009), 108-109. https://doi.org/10.31046/tl.v2i1.88

“Encyclopedia of the Bible and Its Reception,” Bergant, Diane and Dunkly, James, 2:2 (2009), 98-102. https:// doi.org/10.31046/tl.v2i2.117

“Encyclopedia of the Historical Jesus,” Hogan, Derek K., 2:1 (2009), 96-97. https://doi.org/10.31046/tl.v2i1.76

“The Encyclopedia of Time: Science, Philosophy, Theology \& Culture,” Steffel, Nick, 3:1 (2010), 67-68. https:// doi.org/10.31046/tl.v3i1.126

“Encyclopedia of Women in Today’s World,” Lipton, Saundra, 5:1 (2012), 87-88. https://doi.org/10.31046/ tl.v5i1.218

“Esther: A Handbook on the Hebrew Text,” Schmersal, David Edward, 9:1 (2016), 45-46. https://doi. org/10.31046/tl.v9i1.417

“Faith Across Time,” Jaeger, John David, 8:1 (2015), 81-82. https://doi.org/10.31046/tl.v8i1.354

"Feminist Biblical Interpretation: A Compendium of Critical Commentary on the Books of the Bible and Related Literature,” Bidlack, Beth, 7:1 (2014), 65-66. https://doi.org/10.31046/tl.v7i1.313

“Find it in the Talmud," Bartholomew, Jennifer K., 8:2 (2015), 56. https://doi.org/10.31046/tl.v8i2.405

“Fortress Commentary on the Bible,” McLaurin, III, Dougald W, 8:2 (2015), 67-68. https://doi.org/10.31046/ tl.v8i2.400

“Global Dictionary of Theology,” Phillips, Robert, 2:2 (2009), 118-120. https://doi.org/10.31046/tl.v2i2.114

“A Guide for Writing about Theology and Religion,” Rozear, Hannah, 6:2 (2013), 81-82. https://doi.org/10.31046/ tl.v6i2.272

“Guide to Islamist Movements,” Frost, Ellen, 5:1 (2012), 79-80. https://doi.org/10.31046/tl.v5i1.208

“Handbook for the Study of the Historical Jesus,” Trott, Garrett, 5:1 (2012), 94-95. https://doi.org/10.31046/ tl.v5i1.190

“Handbook of Theological Education in World Christianity,” Iwaskov, Tracy Powell, 4:1 (2011), 110-111. https://doi.org/10.31046/tl.v4i1.185 
“A Handbook to Old Testament Exegesis,” Redding, Jonathan David, 11:1 (2018), 51-52. https://doi. org/10.31046/tl.v11i1.495

“Historical Dictionary of Catholicism,” Harty, Kathy, 6:2 (2013), 67-68. https://doi.org/10.31046/tl.v6i2.302

“Historical Dictionary of the Coptic Church,” Bohleke, B., 3:1 (2010), 48-50. https://doi.org/10.31046/tl.v3i1.138

“The History of Western Philosophy of Religion,” Skinner, Michael, 3:2 (2010), 69-71. https://doi.org/10.31046/ tl.v3i2.152

“IATG3: Internationales Abkürzungsverzeichnis für Theologie und Grenzgebiete,” Turner, Bob, 9:1 (2016), 61. https://doi.org/10.31046/tl.v9i1.414

“The Illustrated Guide to Islam,” Manzoor, Romana G., 6:2 (2013), 69-70. https://doi.org/10.31046/tl.v6i2.292

"An Index to English Periodical Literature on the Old Testament and Ancient Near Eastern Studies: Volume IX,” Whitford, Philip, 6:1 (2013), 94-95. https://doi.org/10.31046/tl.v6i1.260

“The Information Behavior of a New Generation: Children and Teens in the 21st Century,” Roach, Jonathan Chad, 6:2 (2013), 77-78. https://doi.org/10.31046/tl.v6i2.281

“The Information: A History, A Theory, A Flood,” Lincoln, Timothy Dwight, 5:1 (2012), 85-86. https://doi. org/10.31046/tl.v5i1.201

“Innovative Solutions for Building Community in Academic Libraries,” Darling, Kay, 9:2 (2016), 31-32. https:// doi.org/10.31046/tl.v9i2.446

"Inquiry and Research: A Relational Approach in the Classroom,” Smith, Daniel, 12:1 (2019), 63-64. https:// doi.org/10.31046/tl.v12i1.538

“An Interpretive Lexicon of New Testament Greek,” Fowler, Jason, 10:1 (2017), 45. https://doi.org/10.31046/ tl.v10i1.467

“An Introductory Dictionary of Theology and Religious Studies,” Willkom, Renee Catherine, 2:1 (2009), 110-112. https://doi.org/10.31046/tl.v2i1.71

“Jesus in History, Legend, Scripture, and Tradition: A World Encyclopedia,” Adkins, Martha, 9:1 (2016), 52-53. https://doi.org/10.31046/tl.v9i1.422

“Jewish Annotated New Testament,” Moll, Kirk A., 5:2 (2012), 95-96. https://doi.org/10.31046/tl.v5i2.244

“Leadership in Theological Education,” Phillips, Robert, 11:2 (2018), 42-43. https://doi.org/10.31046/ tl.v11i2.527

“Libraries and Archives: A Comparative Study,” Cox, David E., 7:1 (2014), 67. https://doi.org/10.31046/ tl.v7i1.310

“Marketing Today’s Academic Library: A Bold New Approach to Communicating with Students," Ganski, Kate L, 2:2 (2009), 105-106. https://doi.org/10.31046/tl.v2i2.100

“Masterplots II: Christian Literature,” Benda, Chris, 1:2 (2008), 77-79. https://doi.org/10.31046/tl.v1i2.49

“Melton's Encyclopedia of American Religions,” Hamilton, Barry W., 2:2 (2009), 107-108. https://doi. org/10.31046/tl.v2i2.103

“Mentoring in the Library: Building for the Future,” McMahon, Melody Layton, 5:1 (2012), 89-90. https://doi. org/10.31046/tl.v5i1.182

“More Technology for the Rest of Us," Tait, Jennifer Woodruff, 3:2 (2010), 72-73. https://doi.org/10.31046/ tl.v3i2.168 
“Muhammad in History, Thought, and Culture," Cox, David E., 8:2 (2015), 59-60. https://doi.org/10.31046/ tl.v8i2.376

“New Catholic Encyclopedia Supplement 2009,” Hayes, Elyse, $2: 2$ (2009), 109-111. https://doi.org/10.31046/ tl.v2i2.115

“New International Dictionary of New Testament Theology and Exegesis,” Darlack, James Marion, 9:1 (2016), 50-51. https://doi.org/10.31046/tl.v9i1.421

“The New Interpreter's Handbook of Preaching,” Shepherd, William H., 2:2 (2009), 121-123. https://doi. org/10.31046/tl.v2i2.104

“New Routes to Library Success,” Morris, Angela G., 9:2 (2016), 33-34. https://doi.org/10.31046/tl.v9i2.445

“The New Westminster Dictionary of Church History,” Leahy, Elizabeth A., 3:1 (2010), 58-59. https://doi. org/10.31046/tl.v3i1.139

"Now You See It: How the Brain Science of Attention Will Transform the Way We Live, Work, and Learn," Wenderoth, Christine, 5:2 (2012), 99-100. https://doi.org/10.31046/tl.v5i2.236

“Open Access,” Stewart, David R., 7:1 (2014), 72-74. https://doi.org/10.31046/tl.v7i1.323

“Oxford Biblical Studies Online,” Gonzalez, Lisa, 2:1 (2009), 91-93. https://doi.org/10.31046/tl.v2i1.85

“The Oxford Companion to the Book,” Eldevik, Bruce Eugene, 3:2 (2010), 54-56. https://doi.org/10.31046/ $\underline{\text { tl.v3i2.156 }}$

“The Oxford Dictionary of the Jewish Religion,” Bartholomew, Jennifer K., 5:1 (2012), 77-78. https://doi. org/10.31046/tl.v5i1.214

“Oxford Dictionary of the Bible and Archaeology," Swanson, Dennis M., 7:1 (2014), 75-76. https://doi. org/10.31046/tl.v7i1.322

“The Oxford Encyclopaedia of South Asian Christianity,” Phillips, Robert, 6:2 (2013), 74-76. https://doi. org/10.31046/tl.v6i2.301

“Oxford Encyclopedia of Biblical Interpretation,” Senapatiratne, Timothy, 7:2 (2014), 62-63. https://doi. org/10.31046/tl.v7i2.333

“The Oxford Encyclopedia of the Books of the Bible," Hanson, Susanah J, 5:2 (2012), 85-87. https://doi. org/10.31046/tl.v5i2.222

“The Oxford Handbook of African American Theology,” Murrain, Shanee Yvette, 10:1 (2017), 48-49. https:// doi.org/10.31046/tl.v10i1.468

“The Oxford Handbook of Christianity and Economics,” Lillard, Justin Matthew, 8:1 (2015), 83-84. https:// doi.org/10.31046/tl.v8i1.355

“The Oxford Handbook of Early Christian Studies,” Mukunthan, Cumaraswamy Michael, 2:2 (2009), 112-114. https://doi.org/10.31046/tl.v2i2.94

“The Oxford Handbook of Interdisciplinarity,” Harper, Wakefield, 5:2 (2012), 88-89. https://doi.org/10.31046/ tl.v5i2.228

“The Oxford Handbook of Religious Conversion,” Bales, John Glenn, 8:1 (2015), 77-78. https://doi.org/10.31046/ tl.v8i1.371

“The Pastor's Library: An Annotated Bibliography of Biblical and Theological Resources for Ministry,” Rosenbeck, Craig, 11:2 (2018), 44. https://doi.org/10.31046/tl.v11i2.528 
“The Personal Librarian: Enhancing the Student Experience,” Gucker, Jacob W., 8:2 (2015), 65-66. https:// doi.org/10.31046/tl.v8i2.402

“Personenlexikon zum Zweiten Vatikanischen Konzil," Cox, David E., 8:1 (2015), 79-80. https://doi. org/10.31046/tl.v8i1.339

“Pocket Dictionary of Theological Terms,” Bartholomew, Jennifer K., 9:1 (2016), 49. https://doi.org/10.31046/ tl.v9i1.419

“Practical Tips for Facilitating Research," Stevens, Kerrie, 9:2 (2016), 37. https://doi.org/10.31046/tl.v9i2.443

“The Praeger Handbook of Religion and Education in the United States," Shaffett, John E., 3:1 (2010), 64-66. https://doi.org/10.31046/tl.v3i1.127

“The Princeton Encyclopedia of Islamic Political Thought,” Skreslet, Paula Youngman, 6:2 (2013), 83-85. https://doi.org/10.31046/tl.v6i2.290

"Pushing the Margins: Women of Color and Intersectionality in LIS," Murphy, Ondrea M., 12:1 (2019), 61-62. https://doi.org/10.31046/tl.v12i1.540

“The Quality Library: A Guide to Staff-Driven Improvement, Better Efficiency, and Happier Customers," Burnam, Paul D., 2:1 (2009), 89-90. https://doi.org/10.31046/tl.v2i1.70

“RDA Toolkit,” Kettner, Megan, 4:1 (2011), 105-106. https://doi.org/10.31046/tl.v4i1.175

“Reading for Faith and Learning,” Sheppard, Beth M., 10:1 (2017), 50-52. https://doi.org/10.31046/tl.v10i1.476

"Reference Guide to Christian Missionary Societies in China and Christianity in China: A Scholar's Guide to Resources in the Libraries and Archives of the United States," DeLong, Linwood, 3:2 (2010), 51-53. https:// doi.org/10.31046/tl.v3i2.145

“Religion and American Cultures: Tradition, Diversity, and Popular Expression, 2nd Edition,” Ost, Brad, 9:1 (2016), 47-48. https://doi.org/10.31046/tl.v9i1.418

“Religion and the Law in America," Guyette, Fred, 2:1 (2009), 94-95. https://doi.org/10.31046/tl.v2i1.55

“The Religion and Theology Student Writer's Manual and Reader's Guide,” Shrauner, Ryan Douglas, 12:1 (2019), 68-70. https://doi.org/10.31046/tl.v12i1.539

"Religion and Violence: An Encyclopedia of Faith and Conflict from Antiquity to the Present," McMullen, Kenneth, 5:1 (2012), 91-93. https://doi.org/10.31046/tl.v5i1.199

“Religion Past and Present,” Wright, Logan S, 1:2 (2008), 93-95. https://doi.org/10.31046/tl.v1i2.46

"Religious Celebrations: An Encyclopedia of Holidays, Festivals, Solemn Observances, and Spiritual Commemorations,” Morris, Angela G., 5:2 (2012), 97-98. https://doi.org/10.31046/tl.v5i2.239

“Religious Leadership: A Reference Handbook,” Burr, Trisha A., 7:2 (2014), 54-55. https://doi.org/10.31046/ tl.v7i2.337

“Religious Nationalism: A Reference Handbook,” Dekker, Jennifer, 7:1 (2014), 70-71. https://doi.org/10.31046/ tl.v7i1.320

"Research and Writing in the Seminary: Practical Strategies and Tools," Berryhill, Carisse, 8:2 (2015), 57-58. https://doi.org/10.31046/tl.v8i2.406

“Routledge Companion to Christian History,” Schottler, Sophie, 1:2 (2008), 89-90. https://doi.org/10.31046/ tl.v1i2.52

“The Routledge Companion to Religion and Popular Culture,” Wason, Brandon C., 9:2 (2016), 42-43. https:// doi.org/10.31046/tl.v9i2.432 
“The Routledge Companion to the Practice of Christian Theology,” Trott, Garrett, 9:2 (2016), 40-41. https:// doi.org/10.31046/tl.v9i2.449

“The Routledge Handbook of Research Methods in the Study of Religion,” Roland, Daniel R., 6:2 (2013), 79-80. https://doi.org/10.31046/tl.v6i2.285

“The SBL Handbook of Style, 2nd Edition,” Rosauer, Greg, 9:1 (2016), 54-56. https://doi.org/10.31046/tl.v9i1.424

“Scholarly Communications: A History from Content as King to Content as Kingmaker," Boyd, Evan E., 9:1 (2016), 57-58. https://doi.org/10.31046/tl.v9i1.425

"Search Committees: A Comprehensive Guide to Successful Faculty, Staff, and Administrative Searches," Roach, Jonathan Chad, 8:1 (2015), 87-88. https://doi.org/10.31046/tl.v8i1.351

“Staff Development on a Shoestring,” Shaffett, John E., 6:1 (2013), 90-91. https://doi.org/10.31046/tl.v6i1.241

“STEP Bible,” Miller, Elizabeth Young, 11:1 (2018), 58-59. https://doi.org/10.31046/tl.v11i1.503

“Supporting Digital Humanities for Knowledge Acquisition in Modern Libraries,” Taylor, Sharon A., 9:2 (2016), 38-39. https://doi.org/10.31046/tl.v9i2.429

“T\&T Clark Companion to Methodism,” Keck, Andrew J., 5:1 (2012), 83-84. https://doi.org/10.31046/tl.v5i1.215

“T\&T Clark Handbook to Social Identity in the New Testament,” Gonzalez, Lisa, 9:1 (2016), 59-60. https://doi. org/10.31046/tl.v9i1.426

“Theologians and Philosophers Using Social Media: Advice, Tips, and Testimonials,” Tait, Jennifer Woodruff, 11:1 (2018), 60. https://doi.org/10.31046/tl.v11i1.510

“Voices of Early Christianity: Documents from the Origins of Christianity,” Webb, Lee, 7:1 (2014), 79-80. https://doi.org/10.31046/tl.v7i1.318

“Westminster Dictionary of Theologians," Siedlecki, Armin, 1:2 (2008), 91-92. https://doi.org/10.31046/ tl.v1i2.42

“Words of Wisdom: A Philosophical Dictionary for the Perennial Tradition,” Ost, Brad, 6:1 (2013), 86-87. https://doi.org/10.31046/tl.v6i1.248

"World Biographical Information System (WBIS Online) and the Biographical Archive of Christianity (BAChr)," Anderson, Christopher J., 4:1 (2011), 96-97. https://doi.org/10.31046/tl.v4i1.176

“Worship in the Early Church,” Brennan, Christopher, 3:2 (2010), 45-47. https://doi.org/10.31046/tl.v3i2.148

\section{Editorials}

“Achieving Literary Liftoff,” Stewart, David R., 7:2 (2014), iii. https://doi.org/10.31046/tl.v7i2.341

“Authors on Authoring,” Stewart, David R. and Crown, Ronald W., 5:1 (2012), iii. https://doi.org/10.31046/ tl.v5i1.219

“Changes Afoot,” Stewart, David R., 8:2 (2015), iii. https://doi.org/10.31046/tl.v8i2.394

“Editorial,” Stewart, David R., 4:1 (2011), iii. https://doi.org/10.31046/tl.v4i1.196

“Editorial Board Introductions,” Tait, Jennifer Woodruff, 10:1 (2017), iii. https://doi.org/10.31046/tl.v10i1.469

“Editor's Adios,” Stewart, David R., 9:1 (2016), iii. https://doi.org/10.31046/tl.v9i1.416

“From the Co-Editors,” Crown, Ronald W. and Stewart, David R., 3:2 (2010), iii. https://doi.org/10.31046/ tl.v3i2.170 
“In Praise of the Generalist: Reflecting on the Librarian’s Challenge,” Adams, Richard Manly, Jr., 12:1 (2019), iii. https://doi.org/10.31046/tl.v12i1.545

“In Search of a ‘Culture of Writing,”, Stewart, David R., 8:1 (2015), iii. https://doi.org/10.31046/tl.v8i1.375

“A New Era for Theological Librarianship," Bennett, Miranda H., Daught, Gary F. and Estelle-Holmer, Suzanne M., 9:2 (2016), iii. https://doi.org/10.31046/tl.v9i2.448

“A Note to Prospective Authors,” Editorial Team, 1:1 (2008), 5. https://doi.org/10.31046/tl.v1i1.39

“Novice Contributor Tells All,” Stewart, David R., 7:1 (2014), iii. https://doi.org/10.31046/tl.v7i1.330

“'Oh, the Editor's Life is the Life for Me ...,” Stewart, David R., 6:1 (2013), iii. https://doi.org/10.31046/tl.v6i1.267

“Our Second Issue,” Crown, Ronald W and Stewart, David R., 1:2 (2008), 3. https://doi.org/10.31046/tl.v1i2.65

“'Quinquennial' - Reflecting on TL’s Fifth Anniversary,” Stewart, David R., 6:2 (2013), iii. https://doi. org/10.31046/tl.v6i2.306

“Theological Librarianship at 10: A Long Look Back, a Long Look Forward,” Tait, Jennifer Woodruff, 11:2 (2018), iii-viii. https://doi.org/10.31046/tl.v11i2.526

“Two Years On,” Crown, Ronald W. and Stewart, David R., 2:2 (2009), iii. https://doi.org/10.31046/tl.v2i2.124

"Welcome to Our Third Issue of Theological Librarianship," Crown, Ronald W., 2:1 (2009), iii. https://doi. org/10.31046/tl.v2i1.93

“Welcome to Theological Librarianship,” Norlin, Dennis A., 1:1 (2008), 3. https://doi.org/10.31046/tl.v1i1.36

“We're All Librarians Now?” Tait, Jennifer Woodruff, 11:1 (2018), iii. https://doi.org/10.31046/tl.v11i1.509

“Why Theological Librarianship?” Crown, Ronald W. and Stewart, David R., 1:1 (2008), 4. https://doi.org/10.31046/ tl.v1i1.35

“Why Write for Peer Review?” Crown, Ronald W., 5:2 (2012), iii. https://doi.org/10.31046/tl.v5i2.246

“Why Write?” Stewart, David R. and Crown, Ronald W., 3:1 (2010), iii. https://doi.org/10.31046/tl.v3i1.147

\section{Essays}

“'Awash in a Sea of Archives': Key Research Sources in the United States for the Study of Mission and World Christianity,” Dries, Angelyn, 5:2 (2012), 23-28. https://doi.org/10.31046/tl.v5i2.232

“Benedict Biscop: Benedictine, Builder, Bibliophile,” Olley, Lorraine H., 7:1 (2014), 30-37. https://doi. org/10.31046/tl.v7i1.297

"The Best Cataloger is a Frustrated Library User: Cataloging Failure and the Underutilization of Library Resources,” Thompson, John W., 8:2 (2015), 22-27. https://doi.org/10.31046/tl.v8i2.401

“A Case for Slow Reading,” Ostercamp, Matthew J, 7:2 (2014), 9-19. https://doi.org/10.31046/tl.v7i2.338

“The Catholic Church Extension Society Records at Loyola University Chicago,” Young, Kathryn A., 9:2 (2016), 28-29. https://doi.org/10.31046/tl.v9i2.440

“Catholic Pamphlets at the Hesburgh Libraries,” McManus, Jean C., 9:2 (2016), 15-18. https://doi.org/10.31046/ tl.v9i2.441

“The Center for Adventist Research at Andrews University,” Robertson, Terry Dwain, Burt, Merlin D. and Ford, Jim, 8:1 (2015), 24-29. https://doi.org/10.31046/tl.v8i1.368

“The Church Club of New York Library,” Rider, Jacqueline H., 6:2 (2013), 29-33. https://doi.org/10.31046/ tl.v6i2.296 
“Citation Analysis and Its Potential In Theological Libraries," Gundry, Jenifer, Senapatiratne, Timothy and Trott, Garrett, 8:2 (2015), 16-21. https://doi.org/10.31046/tl.v8i2.389

"Counting the Costs of Acquisitions: Using Cost-Benefit Analysis in a Seminary and University Library," Getahun, Verena and Keillor, William A., 2:2 (2009), 24-35. https://doi.org/10.31046/tl.v2i2.108

“The Curious Case of a 'Mayflower Bible'," Coates, Carolyn K., 1:2 (2008), 7-15. https://doi.org/10.31046/ tl.v1i2.59

“Effective Leadership in Tough Times: Three Essays," Hook, William .J, Myers, Sara J. and Taylor, Sharon A., 2:1 (2009), 20-34. https://doi.org/10.31046/tl.v2i1.92

“Fake News, Confirmation Bias, the Search for Truth, and the Theology Student,” Badke, William, 11:2 (2018), 4-7. https://doi.org/10.31046/tl.v11i2.519

"The Fine Art of Throwing Sheep: How Facebook Can Contribute to Librarianship and Community in Theological Institutions,” Spomer, Michelle Y., 1:1 (2008), 10-21. https://doi.org/10.31046/tl.v1i1.37

"Flip Over Research Instruction: Delivery, Assessment, and Feedback Strategies for ‘Flipped' Library,” Rosser, Christopher Michael and Willis, Tamie, 9:1 (2016), 22-27. https://doi.org/10.31046/tl.v9i1.413

"FRBR and RDA: What They Are and How They May Affect the Future of Libraries," Croissant, Charles R., 5:2 (2012), 6-22. https://doi.org/10.31046/tl.v5i2.234

“From the Ground Up: Starting a Theological Library from Scratch,” Truman, Gerald, 3:1 (2010), 23-26. https://doi.org/10.31046/tl.v3i1.133

"Funding the Future of African American Religion Archival Collections," Jackson, Andrea, Wiseman, Christine and Ost, Brad, 9:1 (2016), 16-21. https://doi.org/10.31046/tl.v9i1.409

“The Future of the Small Theological Library,” Stephens, Myka Kennedy, 9:1 (2016), 28-32. https://doi. org/10.31046/tl.v9i1.411

“Greater Than the Sum of Its Parts: The Shared Wealth of Scholarly Resources in the Catholic Portal," Maher, Diane, 9:2 (2016), 12-14. https://doi.org/10.31046/tl.v9i2.438

"An Historical Assessment of the Narrative Uses of the Words 'Kabbalah,' 'Cabala,' and 'Qabala/h': Discerning the Differences for Theological Libraries,” Elia, Anthony J, 2:2 (2009), 11-23. https://doi.org/10.31046/ tl.v2i2.111

“The Historical Value of Parish Histories,” Rzeznik, Thomas F., 9:2 (2016), 19-22. https://doi.org/10.31046/ tl.v9i2.442

“Incorporating Concepts of Hospitality into Theological Library Assessment,” Gundry, Jenifer, 8:1 (2015), 10-15. https://doi.org/10.31046/tl.v8i1.366

“An Invisible Wall: The Relationship Between Congregational and Seminary Libraries in the United States," Eliceiri, Rebecca Klemme, 7:1 (2014), 28-29. https://doi.org/10.31046/tl.v7i1.324

“The John Stokes and Mary’s Gardens Collection,” Soule, Stephanie L. and Ewalt, Jillian, 9:2 (2016), 23-27. https://doi.org/10.31046/tl.v9i2.439

“Latinos' Informational Needs in Attaining Accredited Theological Education,” Saxton, Filomena, 7:2 (2014), 20-25. https://doi.org/10.31046/tl.v7i2.342

“Librarians, Publishers, and Theological Reference Resources: A Way Forward," McMahon, Melody Layton, 2:1 (2009), 8-19. https://doi.org/10.31046/tl.v2i1.86 
“Librarianship as a Spiritual Practice,” Wigner, Dann, 10:1 (2017), 2-4. https://doi.org/10.31046/tl.v10i1.455 “Libraries and Universal Design,” Spina, Carli, 10:1 (2017), 5-7. https://doi.org/10.31046/tl.v10i1.464

"The Library of the Universidad Bíblica Latinoamericana: 75th Anniversary in the Midst of Changes," Guzman, Alvaro Perez, 4:1 (2011), 8-15. https://doi.org/10.31046/tl.v4i1.195

“The Marjory Stanway Collection of African Language Materials at Trinity School for Ministry," Hanson, Susanah J., 6:1 (2013), 16-20. https://doi.org/10.31046/tl.v6i1.259

"Ministers on the Lecture Circuit: Education, Entertainment and Religion in Early 20th Century America," Gonzalez, Lisa, 7:1 (2014), 21-27. https://doi.org/10.31046/tl.v7i1.314

“An Open Access Source for the Study of Religion and the Law: The Proceedings of the Old Bailey: London's Central Criminal Court 1674-1913," Guyette, Fred, 1:2 (2008), 28-37. https://doi.org/10.31046/tl.v1i2.60

“The Perennial Question and a Radical Response: The Student Bibliographer Program in the Vanderbilt Divinity Library,” Crawford, Eileen, 6:2 (2013), 9-19. https://doi.org/10.31046/tl.v6i2.273

“'Playing Well With Others': New Opportunities for Library Consortia,” Wiser, James, 5:2 (2012), 43-47. https:// doi.org/10.31046/tl.v5i2.237

“The Qumran Visualization Project: Prospects for Digital Humanities in Theological Libraries,” Murphy, Benjamin P., 5:2 (2012), 29-38. https://doi.org/10.31046/tl.v5i2.240

“'Raising an Ebenezer': Archives as a Religious Means of Remembering,” Malone, David Brian, 8:1 (2015), 16-19. https://doi.org/10.31046/tl.v8i1.369

“A Remarkable Collection of Rare Scriptures in a Small University Library Setting,” Ellis, Teresa Cardin, 6:2 (2013), 20-28. https://doi.org/10.31046/tl.v6i2.298

"Running with Perseverance: The Theological Library's Challenge of Keeping Pace With Changing Students," Falciani-White, Nancy K., 1:2 (2008), 16-27. https://doi.org/10.31046/tl.v1i2.61

"Secret Sisters: Women Religious under European Communism Collection at the Catholic Theological Union," Tinerella, Vincent P., 3:2 (2010), 8-15. https://doi.org/10.31046/tl.v3i2.154

"Seeing the Salzburgers in their Books," Reeves, Timothy Scott, 11:1 (2018), 1-11. https://doi.org/10.31046/ tl.v11i1.474

"Small Change, Big Impact: Assessment and Creative Re-purposing of Underutilized Space at the BU Theology Library,” Smith, Sean, 12:1 (2019), 1-2. https://doi.org/10.31046/tl.v12i1.536

“Tales of an Editor,” Tait, Jennifer Woodruff, 9:1 (2016), 33-37. https://doi.org/10.31046/tl.v9i1.412

“Telling the Library's Story: A Personal Reflection,” Stuehrenberg, Paul, 5:2 (2012), 39-42. https://doi. org/10.31046/tl.v5i2.235

"Theological Librarian vs. Machine: Taking on the Amazon Alexa Show (with Some Reflections on the Future of the Profession)," Sheppard, Beth M., 10:1 (2017), 8-23. https://doi.org/10.31046/tl.v10i1.475

“Theological Librarians and Collection Management: Collaborative Policy Development,” Mayer, Robert J, 11:2 (2018), 8-11. https://doi.org/10.31046/tl.v11i2.530

“Theological Librarianship from a Distance,” Detar, Melody Diehl, 8:2 (2015), 11-15. https://doi.org/10.31046/ tl.v8i2.390

“Theological Librarianship: An Unapologetic Apology,” McMahon, Melody Layton, 3:1 (2010), 7-14. https:// doi.org/10.31046/tl.v3i1.131 
“Theological Libraries and International Collaboration in Southeast Asia,” Stuehrenberg, Paul, 4:1 (2011), 32-40. https://doi.org/10.31046/tl.v4i1.194

“There is Nothing New Under the Sun?: ‘New Librarianship’ and the Theological Library,” Osinski, Keegan, 8:1 (2015), 20-23. https://doi.org/10.31046/tl.v8i1.370

“Three Catholic Libraries in London,” McMahon, Melody Layton, 4:1 (2011), 22-31. https://doi.org/10.31046/ tl.v4i1.192

“Toward a Greater Discourse: Issues in Religious Archives,” Presutti, Robert, 3:1 (2010), 15-22. https://doi. org/10.31046/tl.v3i1.135

"Uganda Christian University: A Center of Excellence in the Heart of Africa-An Overview of the UCU Library," Kiyaga, John, 4:1 (2011), 16-21. https://doi.org/10.31046/tl.v4i1.193

“An Unknown Exegete: Uncovering the Biblical Scholarship of Elizabeth Barrett Browning," Elia, Anthony J, 7:1 (2014), 8-20. https://doi.org/10.31046/tl.v7i1.266

“Using Technology for Ministry: Trends, Principles and Applications,” Vergel, Alfredo, 3:2 (2010), 16-21. https://doi.org/10.31046/tl.v3i2.128

“'We Desire Everything Illustrating the History of Methodism That We Can Procure': Examining the Methodist Collections at Drew University,” Anderson, Christopher J., 6:1 (2013), 9-15. https://doi.org/10.31046/ tl.v6i1.264

\section{Peer-Reviewed Articles}

"By the Numbers: Bibliometrics and Altmetrics as Measures of Faculty Impact in the Field of Religion," Sheppard, Beth M., 8:2 (2015), 28-36. https://doi.org/10.31046/tl.v8i2.357

"Christian Librarians and the Ethics of the Library Bill of Rights," Kaihoi, Scott, 8:1 (2015), 42-60. https://doi. org/10.31046/tl.v8i1.353

“The Comprehensive Theological Bibliography: What is its Future?” Rogers, Anthony D, 5:2 (2012), 48-58. https://doi.org/10.31046/tl.v5i2.203

“Encouraging a Positive Outlook: The Benefits of Appreciative Inquiry in a Theological Library, Miller, Rebecca Louise, Denneque, Seblewongel A and Cunningham, Paige Comstock, 7:1 (2014), 47-55. https:// doi.org/10.31046/tl.v7i1.312

"An Evaluation of the Accessibility of E-resources from Theological Library Websites," Ganski, Kate L., 1:1 (2008), 38-45. https://doi.org/10.31046/tl.v1i1.14

"An Evaluation of the Classification Scheme for Adventists and Ellen White," Tan, Felipe E., Robertson, Terry Dwain, 11:1 (2018), 28-36. https://doi.org/10.31046/tl.v11i1.473

“Expertise and Service: A Call to Action,” Butler, Rebecca, 8:1 (2015), 30-41. https://doi.org/10.31046/tl.v8i1.352

“Finding Religion: An Analysis of Theology LibGuides,” Van Dyk, Gerrit, 8:2 (2015), 37-45. https://doi. org/10.31046/tl.v8i2.384

"From Intention to Composition: How Seminarians Conceptualize Research," Lincoln, Timothy Dwight and Lincoln, Laura Marie, 4:1 (2011), 41-67. https://doi.org/10.31046/tl.v4i1.178

“A Gentle Introduction to Topic Modeling Using Python,” Saxton, Micah D., 11:1 (2018), 18-27. https://doi. org/10.31046/tl.v11i1.506

“Hebrew Language Resources,” Goodwin, Shawn Virgil, 12:1 (2019), 24-39. https://doi.org/10.31046/ $\underline{\text { tl.v12i1.493 }}$ 
“The Impact of Distance Education on Libraries,” Boyd, Kenneth A., 2:1 (2009), 35-44. https://doi.org/10.31046/ tl.v2i1.75

"Information Needs and Behaviours of Theology Students at the International Baptist Theological Seminary," Penner, Katharina, 2:2 (2009), 51-80. https://doi.org/10.31046/tl.v2i2.99

“Information Seeking Behavior of the Ulama in Relation to Preaching and Counseling Roles in Nigeria," Saleh, Adam Gambo and Abu Bakar, Ahmed Bakeri, 6:1 (2013), 29-46. https://doi.org/10.31046/tl.v6i1.177

"Library Research Instruction for Doctor of Ministry Students: Outcomes of Instruction Provided by a Theological Librarian and by a Program Faculty Member," Kamilos, Charles D. and Birch, Rodney, 7:1 (2014), 38-46. https://doi.org/10.31046/tl.v7i1.325

“Narratives of Reading in Luke-Acts,” Weaver, John B, 1:1 (2008), 22-37. https://doi.org/10.31046/tl.v1i1.27

“Open Access and Authors' Rights Management: A Possibility for Theology?” Smith, Kevin L., 2:1 (2009), 45-56. https://doi.org/10.31046/tl.v2i1.73

"The Open Access Availability of Articles from Highly Ranked Religious Studies Journals: A Study of Ten Journals,” Avery, Joshua M., 11:1 (2018), 12-17. https://doi.org/10.31046/tl.v11i1.465

"Reading and E-reading for Academic Work: Patterns and Preferences in Theological Studies and Religion," Lincoln, Timothy Dwight, 6:2 (2013), 34-52. https://doi.org/10.31046/tl.v6i2.293

“Recent Research in Religion: A Citation Analysis,” Adkins, Martha, 11:2 (2018), 16-26. https://doi.org/10.31046/ tl.v11i2.507

“The Rise and Fall of Union Classification,” Butler, Rebecca, 6:1 (2013), 21-28. https://doi.org/10.31046/ tl.v6i1.254

“Student Theological Research as an Invitation,” Badke, William, 5:1 (2012), 30-42. https://doi.org/10.31046/ tl.v5i1.200

“Theological Libraries and 'The Next Christendom': Connecting North American Theological Education to Uses of the Book in the Global South,” Weaver, John B., 1:2 (2008), 38-48. https://doi.org/10.31046/tl.v1i2.45

“Theological Libraries and Scholarly Publishing in Religion and Theology,” Keck, Andrew J., 11:2 (2018), 27-37. https://doi.org/10.31046/tl.v11i2.518

“Towards an Online Searchable Bibliographic Database for Ismā 'îlī Studies,” Jiwa, Nawazali Alibhai, 11:1 (2018), 37-50. https://doi.org/10.31046/tl.v11i1.478

“Twenty Years of Theological Markup Languages: A Retro- and Prospective,” MoChridhe, Race J., 12:1 (2019), 40-49. https://doi.org/10.31046/tl.v12i1.523

“Understanding Mormonism: Foundational Sources on its Culture, History, and Theology,” Van Dyk, Gerrit, 12:1 (2019), 50-60. https://doi.org/10.31046/tl.v12i1.531

"Using Sermon Text Archives to Investigate the Construction of Social Values: A Proposal for a Collaborative Research Agenda in Social Epistemology,” Roland, Daniel R., 5:1 (2012), 43-55. https://doi.org/10.31046/ $\underline{\text { tl.v5i1.188 }}$

\section{Special Forums}

\section{Electronic Journals}

“Change, Challenge, Opportunity - a Forum on Electronic Journals," Crown, Ronald W. and Stewart, David R., 2:2 (2009), 36. https://doi.org/10.31046/tl.v2i2.122 
"Wood, Flour, Journal: How the Electronic Turn Has Affected the Way Journals are Found, Used, and Read," Garrett, Jeffrey, 2:2 (2009), 37-42. https://doi.org/10.31046/tl.v2i2.97

“E-Journals and the Seminary Library Context: A Response to Jeffrey Garrett,” Sheppard, Beth M., 2:2 (2009), 43-46. https://doi.org/10.31046/tl.v2i2.109

“In a Parallel Universe? A Response to Jeffrey Garrett,” Wenderoth, Christine, 2:2 (2009), 47-50. https://doi. org/10.31046/tl.v2i2.96

Reshaping of Libraries

“Introduction: The Reshaping of Libraries," Stewart, David R. and Crown, Ronald W., 5:1 (2012), 8. https://doi. org/10.31046/tl.v5i1.220

“The James E. Rolfing Memorial Library, Trinity International University,” Hall, Rebekah, 5:1 (2012), 9-11. https://doi.org/10.31046/tl.v5i1.207

“The Christoph Keller, Jr. Library, General Theological Seminary, New York,” Kadel, Andrew G., 5:1 (2012), 12-15. https://doi.org/10.31046/tl.v5i1.210

“Murphy Memorial Library, Baptist Bible College and Seminary,” Michael, Joshua, 5:1 (2012), 16-18. https:// doi.org/10.31046/tl.v5i1.209

“Library of the Associated Mennonite Biblical Seminary,” Saner, Eileen K., 5:1 (2012), 19-22. https://doi. org/10.31046/tl.v5i1.213

“The Corban University Library,” Trott, Garrett, 5:1 (2012), 23-25. https://doi.org/10.31046/tl.v5i1.211

“The John Richard Allison Library, Regent College,” Williams, Audrey, 5:1 (2012), 26-29. https://doi. org/10.31046/tl.v5i1.217

Professional Development

“Special Forum: Best Professional Development Experiences, Spring 2014,” Pakala, James C., Butler, Rebecca, Darlack, James Marion, Day, Donald E., Kroll, Anna Lois, Amodeo, Anthony, Engelson, Leslie A. and Stewart, David R., 7:2 (2014), 26-30. https://doi.org/10.31046/tl.v7i2.344

Open Access

“Theological Librarianship Talks Open Access,” Tait, Jennifer Woodruff, 10:1 (2017), 24. https://doi.org/10.31046/ tl.v10i1.477

“Better Standards for OA Journals,” Ost, Brad, 10:1 (2017), 25-26. https://doi.org/10.31046/tl.v10i1.479

“Peer-reviewing the Publishers: the Scholarly Open Access Appeals Board, 2013-2016," Hughes, Barnaby, 10:1 (2017), 27-32. https://doi.org/10.31046/tl.v10i1.480

“Religious Studies Journals in Beall's List,” Daught, Gary, 10:1 (2017), 33-39. https://doi.org/10.31046/ tl.v10i1.481

“How Theological Librarianship Came to Be, and Came to Be Open-Access,” Keck, Andrew J., 10:1 (2017), 40. https://doi.org/10.31046/tl.v10i1.482

“Launching an Open Access Journal - Can You Make the Investment?” Gonzalez, Lisa, 10:1 (2017), 41-42. https://doi.org/10.31046/tl.v10i1.483

Prison Libraries

“Theological Libraries in Prison: A Special Forum,” Tait, Jennifer Woodruff, 11:2 (2018), 12. https://doi. org/10.31046/tl.v11i2.532 
“Library Services for the North Carolina Field Minister Program,” Fowler, Jason, 11:2 (2018), 13. https://doi. org/10.31046/tl.v11i2.524

“Prison Theological Librarianship,” Griffin, Jeff, 11:2 (2018), 14. https://doi.org/10.31046/tl.v11i2.508

"Providing Library Services to Prisoners: Calvin College and Calvin Seminary at Handlon Correctional Facility," Malone, David Brian, 11:2 (2018), 15. https://doi.org/10.31046/tl.v11i2.514

Expressions and Encounters: Experiencing the Histories and Theologies of African Christianity in the Collections of Pitts Theology Library

"Expressions and Encounters: Experiencing the Histories and Theologies of African Christianity in the Collections of Pitts Theology Library: An Introduction to an Exhibition and a Forum," Adams, Richard Manly, Jr., 12:1 (2019), 3-4. https://doi.org/10.31046/tl.v12i1.546

"Expressions and Encounters: Experiencing the Histories and Theologies of African Christianity in the Collections of Pitts Theology Library: An Essay on Curatorial Challenges and Responsibilities," Aycock, Jennifer L., 12:1 (2019), 5-12. https://doi.org/10.31046/tl.v12i1.542

"Expressions and Encounters: Experiencing the Histories and Theologies of African Christianity in the Collections of Pitts Theology Library: A Critical Evaluation of an Exhibition,” Jones, Arun W., 12:1 (2019), 13-15. https://doi.org/10.31046/tl.v12i1.544

"Expressions and Encounters: Experiencing the Histories and Theologies of African Christianity in the Collections of Pitts Theology Library: A Visiting Scholar's Reflection,” Mombo, Esther, 12:1 (2019), 16-23. https://doi.org/10.31046/tl.v12i1.543

\section{INDEX OF SUBJECTS}

Academic writing

“Finding Time to Write,” Elder, Jane Lenz, 10:1 (2017), 1. https://doi.org/10.31046/tl.v10i1.471

“Tales of an Editor,” Tait, Jennifer Woodruff, 9:1 (2016), 33-37. https://doi.org/10.31046/tl.v9i1.412

“Information Literacy: Writing Based Research,” Phillips, Robert, 3:2 (2010), 4-5. https://doi.org/10.31046/ tl.v3i2.164

“Information Literacy: A Theological Librarian Reflects on Writers and Writing," Phillips, Robert, 3:1 (2010), 4-5. https://doi.org/10.31046/tl.v3i1.144

Acquisitions

"Counting the Costs of Acquisitions: Using Cost-Benefit Analysis in a Seminary and University Library," Getahun, Verena and Keillor, William A., 2:2 (2009), 24-35. https://doi.org/10.31046/tl.v2i2.108

"Diktuon: Purchasing at the Point of Need: An Acquisitions Pilot Project,” Deeds, Leland, 7:1 (2014), 1-2. https://doi.org/10.31046/tl.v7i1.315

Adventists

“An Evaluation of the Classification Scheme for Adventists and Ellen White," Tan, Felipe E. and Robertson, Terry Dwain, 11:1 (2018), 28-36. https://doi.org/10.31046/tl.v11i1.473

“The Center for Adventist Research at Andrews University," Robertson, Terry Dwain, Burt, Merlin D and Ford, Jim, 8:1 (2015), 24-29. https://doi.org/10.31046/tl.v8i1.368 


\section{Apocryphalbooks}

“Early Christian Apocrypha: A Bibliographic Essay,” Shepherd, William H., 3:1 (2010), 40-47. https://doi. org/10.31046/tl.v3i1.125

Archives

“The Catholic Church Extension Society Records at Loyola University Chicago,” Young, Kathryn A., 9:2 (2016), 28-29. https://doi.org/10.31046/tl.v9i2.440

“'Raising an Ebenezer”: Archives as a Religious Means of Remembering,” Malone, David Brian, 8:1 (2015), 16-19. https://doi.org/10.31046/tl.v8i1.369

“Toward a Greater Discourse: Issues in Religious Archives,” Presutti, Robert, 3:1 (2010), 15-22. https://doi. org/10.31046/tl.v3i1.135

"Funding the Future of African American Religion Archival Collections," Jackson, Andrea, Wiseman, Christine and Ost, Brad, 9:1 (2016), 16-21. https://doi.org/10.31046/tl.v9i1.409

"Using Sermon Text Archives to Investigate the Construction of Social Values: A Proposal for a Collaborative Research Agenda in Social Epistemology,” Roland, Daniel R., 5:1 (2012), 43-55. https://doi.org/10.31046/ tl.v5i1.188

“'Awash in a Sea of Archives': Key Research Sources in the United States for the Study of Mission and World Christianity,” Dries, Angelyn, 5:2 (2012), 23-28. https://doi.org/10.31046/tl.v5i2.232

Assemblies of God

“The Assemblies of God: A Bibliographic Essay,” Senapatiratne, Timothy, 4:1 (2011), 91-95. https://doi. org/10.31046/tl.v4i1.171

Bible

“Five Recent Commentaries on Acts,” Wason, Brandon C., 8:1 (2015), 70-76. https://doi.org/10.31046/tl.v8i1.364

“Teaching the History of the Bible as Book," Eldevik, Bruce Eugene, 9:1 (2016), 38-44. https://doi.org/10.31046/ tl.v9i1.427

“Inner-Biblical Allusion,” Lester, G. Brooke, 2:2 (2009), 89-93. https://doi.org/10.31046/tl.v2i2.110

“Bible Reading Revisited: The Librarian's Guide to Lectio Divina and Formative Styles of Reading," Studzinski, Raymond James, 7:1 (2014), 56-64. https://doi.org/10.31046/tl.v7i1.327

“Going a Step Beyond-Websites with More than Just Bibles,” Kuykendall, Michael, 3:2 (2010), 22-26. https:// doi.org/10.31046/tl.v3i2.159

“An Unknown Exegete: Uncovering the Biblical Scholarship of Elizabeth Barrett Browning,” Elia, Anthony J., 7:1 (2014), 8-20. https://doi.org/10.31046/tl.v7i1.266

“Considerations in Preparing a Biblical Bibliography: Case Study: The Scroll of Esther," Lubetski, Edith and Lubetski, Meir, 3:1 (2010), 31-39. https://doi.org/10.31046/tl.v3i1.129

“The Bible and Handel's Messiah: Some Sources on Their Relation and Use,” Powell, David R., 2:2 (2009), 94-97. https://doi.org/10.31046/tl.v2i2.121

“Narratives of Reading in Luke-Acts,” Weaver, John B., 1:1 (2008), 22-37. https://doi.org/10.31046/tl.v1i1.27

"Resources for the Study of the Classical World in the New Testament Era," Sheppard, Beth M., 5:2 (2012), 67-74. https://doi.org/10.31046/tl.v5i2.223 


\section{Bibliography}

“The Art of the Bibliographic Essay,” Sheppard, Beth M., 1:1 (2008), 46-48. https://doi.org/10.31046/tl.v1i1.29

“Diktuon: Bibliographic Managers,” Keck, Andrew J., 1:2 (2008), 4-5. https://doi.org/10.31046/tl.v1i2.62

"The Perennial Question and a Radical Response: The Student Bibliographer Program in the Vanderbilt Divinity Library,” Crawford, Eileen, 6:2 (2013), 9-19. https://doi.org/10.31046/tl.v6i2.273

“The Comprehensive Theological Bibliography: What is its Future?” Rogers, Anthony D., 5:2 (2012), 48-58. https://doi.org/10.31046/tl.v5i2.203

\section{Bibliometrics}

"By the Numbers: Bibliometrics and Altmetrics as Measures of Faculty Impact in the Field of Religion," Sheppard, Beth M., 8:2 (2015), 28-36. https://doi.org/10.31046/tl.v8i2.357

“Citation Analysis and Its Potential In Theological Libraries,” Gundry, Jenifer, Senapatiratne, Timothy and Trott, Garrett, 8:2 (2015), 16-21. https://doi.org/10.31046/tl.v8i2.389

“The Open Access Availability of Articles from Highly Ranked Religious Studies Journals: A Study of Ten Journals,” Avery, Joshua M., 11:1 (2018), 12-17. https://doi.org/10.31046/tl.v11i1.465

“Recent Research in Religion: A Citation Analysis,” Adkins, Martha, 11:2 (2018), 16-26. https://doi.org/10.31046/ $\underline{\text { tl.v11i2.507 }}$

Biography

“Benedict Biscop: Benedictine, Builder, Bibliophile,” Olley, Lorraine H., 7:1 (2014), 30-37. https://doi. org/10.31046/tl.v7i1.297

“Profiles: John Albert Bollier, 1927-2010,” Estelle-Holmer, Suzanne M., 6:2 (2013), 4-6. https://doi. org/10.31046/tl.v6i2.305

"Influence of the Fathers of the Church on Recent Catholic Conversion Narratives,” Kiczek, Steven Allen, 5:1 (2012), 56-66. https://doi.org/10.31046/tl.v5i1.197

“Father Charles E. Coughlin - the 'Radio Priest’ of the 1930s,” Ketchaver, Karen G., 2:2 (2009), 81-88. https:// doi.org/10.31046/tl.v2i2.112

“Profiles: Fr. Simeon Daly, OSB,” McMahon, Melody Layton, 9:1 (2016), 1-4. https://doi.org/10.31046/tl.v9i1.415

“Profiles: Bibliographer Extraordinaire: Peter De Klerk, 1927-1997,” Schemper, Lugene L, 7:2 (2014), 1-3. https://doi.org/10.31046/tl.v7i2.345

“Profiles: Aspiring Vision and Attention to Detail: Kenneth Sperber Gapp (1905-1966),” Dearborn, Virginia E and Henke, Kenneth W, 8:2 (2015), 1-3. https://doi.org/10.31046/tl.v8i2.396

“Profiles: A Giant in the Land: H. Lucille Hager, 1924-2004,” Eberts, Susan, 8:1 (2015), 1-3. https://doi. org/10.31046/tl.v8i1.373

“Profiles: Doralyn Joanne Hickey, 1929-1987: An Appreciation,” Loyd, Roger, 6:1 (2013), 4-6. https://doi. org/10.31046/tl.v6i1.256

“Profiles: Father Oliver Kapsner, OSB (1902-1991) - A Life in Libraries,” Heintzelman, Matthew, 5:1 (2012), 4-6. https://doi.org/10.31046/tl.v5i1.216

“Ronald Knox: A Bibliographic Essay,” Chappel, James, 1:2 (2008), 49-53. https://doi.org/10.31046/tl.v1i2.44

"Profiles: Quiet Person, Powerfully Loud Influence: Norris Magnuson (1932-2006)," Oslund, Sandra, 9:2 (2016), 9-11. https://doi.org/10.31046/tl.v9i2.433 
“Thomas Merton: American Monk, Artist and Social Critic,” Belcastro, David Joseph, 7:2 (2014), 31-44. https:// doi.org/10.31046/tl.v7i2.334

“Profiles: A Pilgrim's Progress: Decherd Turner, 1922-2002,” Hotchkiss, Valeri, 7:1 (2014), 3-5. https://doi. org/10.31046/tl.v7i1.326

Books and reading

"Reading and E-reading for Academic Work: Patterns and Preferences in Theological Studies and Religion," Lincoln, Timothy Dwight, 6:2 (2013), 34-52. https://doi.org/10.31046/tl.v6i2.293

"Framing Books and Reading: An Exploration of Sixteenth Century Title Borders," Graham, M. Patrick, 6:2 (2013), 53-62. https://doi.org/10.31046/tl.v6i2.291

“A Case for Slow Reading,” Ostercamp, Matthew J., 7:2 (2014), 9-19. https://doi.org/10.31046/tl.v7i2.338

Buddhism

“Zen Garden and No Zen Garden: A Bibliographic Essay,” Masuchika, Glenn Norio, 5:1 (2012), 67-70. https:// doi.org/10.31046/tl.v5i1.204

Cataloging

"An Evaluation of the Classification Scheme for Adventists and Ellen White," Tan, Felipe E. and Robertson, Terry Dwain, 11:1 (2018), 28-36. https://doi.org/10.31046/tl.v11i1.473

"FRBR and RDA: What They Are and How They May Affect the Future of Libraries," Croissant, Charles R., 5:2 (2012), 6-22. https://doi.org/10.31046/tl.v5i2.234

"The Best Cataloger is a Frustrated Library User: Cataloging Failure and the Underutilization of Library Resources," Thompson, John W., 8:2 (2015), 22-27. https://doi.org/10.31046/tl.v8i2.401

“The Rise and Fall of Union Classification,” Butler, Rebecca, 6:1 (2013), 21-28. https://doi.org/10.31046/ tl.v6i1.254

Catholic libraries

“Three Catholic Libraries in London,” McMahon, Melody Layton, 4:1 (2011), 22-31. https://doi.org/10.31046/ tl.v4i1.192

Church fathers

“Bibliographic Essay: Augustine of Hippo,” Fitzgerald, Allan, 8:2 (2015), 46-55. https://doi.org/10.31046/ tl.v8i2.383

“The Librarian's Guide to the Apostolic Fathers,” Jefford, Clayton N., 5:2 (2012), 59-66. https://doi.org/10.31046/ tl.v5i2.224

"Ephrem the Syrian: A Syriac Poet in Armenian Verse," Mathews, Edward George, 5:1 (2012), 71-76. https:// doi.org/10.31046/tl.v5i1.205

Church history

"Growth or Declension: Methodist Historians' Treatment of the Relationship Between the Methodist Episcopal Church and the Culture of the United States,” Teasdale, Mark R., 3:2 (2010), 34-44. https://doi.org/10.31046/ tl.v3i2.163

“The Historical Value of Parish Histories,” Rzeznik, Thomas F., 9:2 (2016), 19-22. https://doi.org/10.31046/ tl.v9i2.442 
“Klostersturm and Secularization in Central Europe: What Happened to the Libraries?” Garrett, Jeffrey, 8:1 (2015), 61-69. https://doi.org/10.31046/tl.v8i1.372

"Ministers on the Lecture Circuit: Education, Entertainment and Religion in Early 20th Century America," Gonzalez, Lisa, 7:1 (2014), 21-27. https://doi.org/10.31046/tl.v7i1.314

“William Penn's Experiment in Religious Freedom: Resources Documenting the Colonial Religious Experience at the State Library of Pennsylvania,” Snavely, Iren Light, 1:2 (2008), 60-76. https://doi.org/10.31046/ tl.v1i2.48

\section{Collection development}

“Theological Librarians and Collection Management: Collaborative Policy Development,” Mayer, Robert J., 11:2 (2018), 8-11. https://doi.org/10.31046/tl.v11i2.530

\section{Databases}

“Towards an Online Searchable Bibliographic Database for Ismā '̄ilì Studies,” Jiwa, Nawazali Alibhai, 11:1 (2018), 37-50. https://doi.org/10.31046/tl.v11i1.478

\section{Digital humanities}

“The Qumran Visualization Project: Prospects for Digital Humanities in Theological Libraries,” Murphy, Benjamin P., 5:2 (2012), 29-38. https://doi.org/10.31046/tl.v5i2.240

"Diktuon: Getting Involved With the Digital Humanities in Theology, Biblical Studies, and Religious Studies," Gerber, Kent T. K., 9:1 (2016), 5-10. https://doi.org/10.31046/tl.v9i1.420

“A Gentle Introduction to Topic Modeling Using Python,” Saxton, Micah D., 11:1 (2018), 18-27. https://doi. org/10.31046/tl.v11i1.506

“Twenty Years of Theological Markup Languages: A Retro- and Prospective,” MoChridhe, Race J., 12:1 (2019), 40-49. https://doi.org/10.31046/tl.v12i1.523

\section{Digital libraries}

“Diktuon: Digital Repositories and Theological Libraries,” Keck, Andrew J., 1:1 (2008), 6-7. https://doi. org/10.31046/tl.v1i1.17

“Featured Web Resource: Theological Commons,” Murray, Gregory P., 9:2 (2016), 1-4. https://doi.org/10.31046/ tl.v9i2.434

“Greater Than the Sum of Its Parts: The Shared Wealth of Scholarly Resources in the Catholic Portal," Maher, Diane, 9:2 (2016), 12-14. https://doi.org/10.31046/tl.v9i2.438

"Introducing the Open Access Digital Theological Library (OADTL): Creating the World's First Entirely Open Access Library in Religious Studies,” Phillips, Thomas E., Baker, Drew and Hidalgo, Ann, 11:2 (2018), 1-3. https://doi.org/10.31046/tl.v11i2.520

“An Open Access Source for the Study of Religion and the Law: The Proceedings of the Old Bailey: London's Central Criminal Court 1674-1913,” Guyette, Fred, 1:2 (2008), 28-37. https://doi.org/10.31046/tl.v1i2.60

\section{Eastern Christianity}

“Christian Traditions in the Contemporary Middle East,” Baker, Matthew, 4:1 (2011), 68-74. https://doi. org/10.31046/tl.v4i1.172 


\section{Electronic books}

“Diktuon: The Kindle 2 - Risk and Promise,” Sheppard, Beth M., 2:2 (2009), 3-8. https://doi.org/10.31046/ tl.v2i2.123

“Diktuon: Finding e-books,” Keck, Andrew J., 3:1 (2010), 1-3. https://doi.org/10.31046/tl.v3i1.143

“Diktuon: A Good Look at the Nook," Sheppard, Beth M., 4:1 (2011), 3-7. https://doi.org/10.31046/tl.v4i1.173

Electronicjournals

"Change, Challenge, Opportunity - a Forum on Electronic Journals," Crown, Ronald W. and Steward, David R., 2:2 (2009), 36. https://doi.org/10.31046/tl.v2i2.122

“E-Journals and the Seminary Library Context: A Response to Jeffrey Garrett,” Sheppard, Beth M., 2:2 (2009), 43-46. https://doi.org/10.31046/tl.v2i2.109

“In a Parallel Universe? A Response to Jeffrey Garrett,” Wenderoth, Christine, 2:2 (2009), 47-50. https://doi. org/10.31046/tl.v2i2.96

"Wood, Flour, Journal: How the Electronic Turn Has Affected the Way Journals are Found, Used, and Read," Garrett, Jeffrey, 2:2 (2009), 37-42. https://doi.org/10.31046/tl.v2i2.97

Graphic novels

“Drawing on God: Theology in Graphic Novels,” Stanley, Sarah, 2:1 (2009), 83-88. https://doi.org/10.31046/ $\underline{\text { tl.v2i1.72 }}$

Hebrew language

“Hebrew Language Resources,” Goodwin, Shawn Virgil, 12:1 (2019), 24-39. https://doi.org/10.31046/ $\underline{\text { tl.v12i1.493 }}$

Information behavior

"Information Needs and Behaviours of Theology Students at the International Baptist Theological Seminary," Penner, Katharina, 2:2 (2009), 51-80. https://doi.org/10.31046/tl.v2i2.99

“Information Behaviour(s) of Theologians: A Literature Review,” Penner, Katharina, 2:1 (2009), 67-82. https:// doi.org/10.31046/tl.v2i1.79

"From Intention to Composition: How Seminarians Conceptualize Research," Lincoln, Timothy Dwight and Lincoln, Laura Marie, 4:1 (2011), 41-67. https://doi.org/10.31046/tl.v4i1.178

"Information Seeking Behavior of the Ulama in Relation to Preaching and Counseling Roles in Nigeria," Saleh, Adam Gambo and Abu Bakar, Ahmed Bakeri, 6:1 (2013), 29-46. https://doi.org/10.31046/tl.v6i1.177

Information literacy

"Fake News, Confirmation Bias, the Search for Truth, and the Theology Student,” Badke, William, 11:2 (2018), 4-7. https://doi.org/10.31046/tl.v11i2.519

“Information Literacy: A Theological Librarian Reflects on Writers and Writing," Phillips, Robert, 3:1 (2010), 4-5. https://doi.org/10.31046/tl.v3i1.144

“Information Literacy: More to Learn-and Teach!” Phillips, Robert, 2:1 (2009), 3-4. https://doi.org/10.31046/ tl.v2i1.84

"Information Literacy: Adaptability and Authenticity-Using the Next Generation's Powers for Good, Not Evil," Norris, Tiffany Davis, 2:2 (2009), 1-2. https://doi.org/10.31046/tl.v2i2.106 
“Diktuon: The Framework for Information Literacy and Theological Education,” Badke, William, 8:2 (2015), 4-7. https://doi.org/10.31046/tl.v8i2.385

International librarianship

“Theological Libraries and International Collaboration in Southeast Asia,” Stuehrenberg, Paul, 4:1 (2011), 32-40. https://doi.org/10.31046/tl.v4i1.194

Islam

“Basic Primary Sources in Islamic Religion,” Skreslet, Paula Youngman, 1:1 (2008), 49-53. https://doi. org/10.31046/tl.v1i1.40

"Information Seeking Behavior of the Ulama in Relation to Preaching and Counseling Roles in Nigeria," Saleh, Adam Gambo and Abu Bakar, Ahmed Bakeri, 6:1 (2013), 29-46. https://doi.org/10.31046/tl.v6i1.177

“Towards an Online Searchable Bibliographic Database for Ismāvīlī Studies,” Jiwa, Nawazali Alibhai, 11:1 (2018), 37-50. https://doi.org/10.31046/tl.v11i1.478

Jesus Christ in film and literature

“The Cinematic Savior: Jesus Films and Related Literature,” Rainey, Jon, 3:2 (2010), 27-33. https://doi. org/10.31046/tl.v3i2.157

Judaism

“An Historical Assessment of the Narrative Uses of the Words 'Kabbalah,' 'Cabala,' and 'Qabala/h': Discerning the Differences for Theological Libraries,” Elia, Anthony J, 2:2 (2009), 11-23. https://doi.org/10.31046/ tl.v2i2.111

“Open Access Liturgical Resources for Judaism,” Nosek, Jason D, 6:2 (2013), 63-66. https://doi.org/10.31046/ tl.v6i2.265

\section{Libraries and distance education}

“The Impact of Distance Education on Libraries,” Boyd, Kenneth A., 2:1 (2009), 35-44. https://doi.org/10.31046/ tl.v2i1.75

“Theological Librarianship from a Distance,” Detar, Melody Diehl, 8:2 (2015), 11-15. https://doi.org/10.31046/ tl.v8i2.390

\section{Libraries and electronic publishing}

“Diktuon: The Library as Publisher? Is It Possible for a Small Library?” McMahon, Melody Layton, 8:1 (2015), 4-6. https://doi.org/10.31046/tl.v8i1.365

"How Theological Librarianship Came to Be, and Came to Be Open-Access," Keck, Andrew J., 10:1 (2017), 40. https://doi.org/10.31046/tl.v10i1.482

“Launching an Open Access Journal - Can You Make the Investment?” Gonzalez, Lisa, 10:1 (2017), 41-42. https://doi.org/10.31046/tl.v10i1.483

“Theological Librarianship at 10: A Long Look Back, a Long Look Forward,” Tait, Jennifer Woodruff, 11:2 (2018), iii-viii. https://doi.org/10.31046/tl.v11i2.526

\section{Library administration}

“Effective Leadership in Tough Times: Three Essays," Hook, William J., Myers, Sara J. and Taylor, Sharon A., 2:1 (2009), 20-34. https://doi.org/10.31046/tl.v2i1.92 
Library cooperation

““Playing Well With Others': New Opportunities for Library Consortia,” Wiser, James, 5:2 (2012), 43-47. https:// doi.org/10.31046/tl.v5i2.237

Library exhibits

"Expressions and Encounters: Experiencing the Histories and Theologies of African Christianity in the Collections of Pitts Theology Library: An Introduction to an Exhibition and a Forum,” Adams, Richard Manly, Jr., 12:1 (2019), 3-4. https://doi.org/10.31046/tl.v12i1.546

"Expressions and Encounters: Experiencing the Histories and Theologies of African Christianity in the Collections of Pitts Theology Library: An Essay on Curatorial Challenges and Responsibilities," Aycock, Jennifer L, 12:1 (2019), 5-12. https://doi.org/10.31046/tl.v12i1.542

"Expressions and Encounters: Experiencing the Histories and Theologies of African Christianity in the Collections of Pitts Theology Library: A Critical Evaluation of an Exhibition,” Jones, Arun W., 12:1 (2019), 13-15. https://doi.org/10.31046/tl.v12i1.544

"Expressions and Encounters: Experiencing the Histories and Theologies of African Christianity in the Collections of Pitts Theology Library: A Visiting Scholar's Reflection," Mombo, Esther, 12:1 (2019), 16-23. https://doi.org/10.31046/tl.v12i1.543

Libraryorientation

"Flip Over Research Instruction: Delivery, Assessment, and Feedback Strategies for 'Flipped' Library,” Rosser, Christopher Michael and Willis, Tamie, 9:1 (2016), 22-27. https://doi.org/10.31046/tl.v9i1.413

"Library Research Instruction for Doctor of Ministry Students: Outcomes of Instruction Provided by a Theological Librarian and by a Program Faculty Member," Kamilos, Charles D. and Birch, Rodney, 7:1 (2014), 38-46. https://doi.org/10.31046/tl.v7i1.325

Library research

“Action Research for Theological Librarians,” Hamilton, Barry W., 1:1 (2008), 54-59. https://doi.org/10.31046/ tl.v1i1.19

“Finding Religion: An Analysis of Theology LibGuides,” Van Dyk, Gerrit, 8:2 (2015), 37-45. https://doi. org/10.31046/tl.v8i2.384

Mormon Church

“Understanding Mormonism: Foundational Sources on its Culture, History, and Theology,” Van Dyk, Gerrit, 12:1 (2019), 50-60. https://doi.org/10.31046/tl.v12i1.531

Open access publishing

“Open Access and Authors’ Rights Management: A Possibility for Theology?” Smith, Kevin L., 2:1 (2009), 45-56. https://doi.org/10.31046/tl.v2i1.73

“TheologicalLibrarianship Talks Open Access,” Tait, Jennifer Woodruff, 10:1 (2017), 24. https://doi.org/10.31046/ tl.v10i1.477

“Better Standards for OA Journals,” Ost, Brad, 10:1 (2017), 25-26. https://doi.org/10.31046/tl.v10i1.479

“Religious Studies Journals in Beall's List,” Daught, Gary, 10:1 (2017), 33-39. https://doi.org/10.31046/ tl.v10i1.481 
“Peer-reviewing the Publishers: the Scholarly Open Access Appeals Board, 2013-2016," Hughes, Barnaby, 10:1 (2017), 27-32. https://doi.org/10.31046/tl.v10i1.480

“The Open Access Availability of Articles from Highly Ranked Religious Studies Journals: A Study of Ten Journals,” Avery, Joshua M., 11:1 (2018), 12-17. https://doi.org/10.31046/tl.v11i1.465

“Open Access Liturgical Resources for Judaism,” Nosek, Jason D., 6:2 (2013), 63-66. https://doi.org/10.31046/ tl.v6i2.265

Prison libraries

“Theological Libraries in Prison: A Special Forum,” Tait, Jennifer Woodruff, 11:2 (2018), 12. https://doi. org/10.31046/tl.v11i2.532

“Library Services for the North Carolina Field Minister Program,” Fowler, Jason, 11:2 (2018), 13. https://doi. org/10.31046/tl.v11i2.524

“Prison Theological Librarianship,” Griffin, Jeff, 11:2 (2018), 14. https://doi.org/10.31046/tl.v11i2.508

"Providing Library Services to Prisoners: Calvin College and Calvin Seminary at Handlon Correctional Facility," Malone, David Brian, 11:2 (2018), 15. https://doi.org/10.31046/tl.v11i2.514

Protestant churches

"Wrestling Long into the Night: Sources on the Mainline Protestant Denominations' Debate about Homosexuality,” Burnam, Paul D., 6:1 (2013), 47-59. https://doi.org/10.31046/tl.v6i1.249

Public services

“Diktuon: Web-based Statistics Trackers,” Rozear, Hannah, 5:2 (2012), 1-3.https://doi.org/10.31046/tl.v5i2.245 Reference services

“Diktuon: Virtual Reference,” Keck, Andrew J., 2:1 (2009), 1-2. https://doi.org/10.31046/tl.v2i1.83

"Librarians, Publishers, and Theological Reference Resources: A Way Forward,” McMahon, Melody Layton, 2:1 (2009), 8-19. https://doi.org/10.31046/tl.v2i1.86

Reorganization of libraries

“The Christoph Keller, Jr. Library, General Theological Seminary, New York,” Kadel, Andrew G., 5:1 (2012), 12-15. https://doi.org/10.31046/tl.v5i1.210

"Small Change, Big Impact: Assessment and Creative Re-purposing of Underutilized Space at the BU Theology Library,” Smith, Sean, 12:1 (2019), 1-2. https://doi.org/10.31046/tl.v12i1.536

“The John Richard Allison Library, Regent College,” Williams, Audrey, 5:1 (2012), 26-29. https://doi. org/10.31046/tl.v5i1.217

“Murphy Memorial Library, Baptist Bible College and Seminary,” Michael, Joshua, 5:1 (2012), 16-18. https:// doi.org/10.31046/tl.v5i1.209

“The Corban University Library,” Trott, Garrett, 5:1 (2012), 23-25. https://doi.org/10.31046/tl.v5i1.211

“Library of the Associated Mennonite Biblical Seminary," Saner, Eileen K., 5:1 (2012), 19-22. https://doi. org/10.31046/tl.v5i1.213

“The James E. Rolfing Memorial Library, Trinity International University,” Hall, Rebekah, 5:1 (2012), 9-11. https://doi.org/10.31046/tl.v5i1.207 
Scholarly publishing

“Theological Libraries and Scholarly Publishing in Religion and Theology,” Keck, Andrew J, 11:2 (2018), 27-37. https://doi.org/10.31046/tl.v11i2.518

Science and religion

“The Work of Evelyn Fox Keller as a Resource for Study in Science and Religion,” Kordesh, Kathleen, 1:2 (2008), 54-59. https://doi.org/10.31046/tl.v1i2.56

\section{Socialmedia}

"The Fine Art of Throwing Sheep: How Facebook Can Contribute to Librarianship and Community in Theological Institutions," Spomer, Michelle Y, 1:1 (2008), 10-21. https://doi.org/10.31046/tl.v1i1.37

“Participatory Cultures and Implications for Theological Education,” Crowley, Eileen D., 6:1 (2013), 60-68. https://doi.org/10.31046/tl.v6i1.251

Special collections

“The Center for Adventist Research at Andrews University,” Robertson, Terry Dwain, Burt, Merlin D. and Ford, Jim, 8:1 (2015), 24-29. https://doi.org/10.31046/tl.v8i1.368

“'We Desire Everything Illustrating the History of Methodism That We Can Procure': Examining the Methodist Collections at Drew University,” Anderson, Christopher J., 6:1 (2013), 9-15. https://doi.org/10.31046/ tl.v6i1.264

“Seeing the Salzburgers in their Books,” Reeves, Timothy Scott, 11:1 (2018), 1-11. https://doi.org/10.31046/ tl.v11i1.474

"A Remarkable Collection of Rare Scriptures in a Small University Library Setting," Ellis, Teresa Cardin, 6:2 (2013), 20-28. https://doi.org/10.31046/tl.v6i2.298

"Secret Sisters: Women Religious under European Communism Collection at the Catholic Theological Union," Tinerella, Vincent P., 3:2 (2010), 8-15. https://doi.org/10.31046/tl.v3i2.154

“Catholic Pamphlets at the Hesburgh Libraries,” McManus, Jean C., 9:2 (2016), 15-18. https://doi.org/10.31046/ tl.v9i2.441

“The John Stokes and Mary’s Gardens Collection,” Soule, Stephanie L. and Ewalt, Jillian, 9:2 (2016), 23-27. https://doi.org/10.31046/tl.v9i2.439

“The Curious Case of a 'Mayflower Bible',” Coates, Carolyn K, 1:2 (2008), 7-15. https://doi.org/10.31046/ tl.v1i2.59

“The Marjory Stanway Collection of African Language Materials at Trinity School for Ministry," Hanson, Susanah J., 6:1 (2013), 16-20. https://doi.org/10.31046/tl.v6i1.259

"William Penn's Experiment in Religious Freedom: Resources Documenting the Colonial Religious Experience at the State Library of Pennsylvania,” Snavely, Iren Light, 1:2 (2008), 60-76. https://doi.org/10.31046/ $\underline{\text { tl.v1i2.48 }}$

Technical services

“Diktuon: Drupal - CMS and Beyond,” Darlack, James Marion, 6:2 (2013), 1-3. https://doi.org/10.31046/ tl.v6i2.304

“Diktuon: Tech Training for a New Age,” Bartholomew, Jennifer K., 3:2 (2010), 1-3. https://doi.org/10.31046/ tl.v3i2.160 
"Diktuon: Providing Library Services in the Cloud: New Benefits Realized, New Skills Required," Hartman, Robin R, 7:2 (2014), 6-8. https://doi.org/10.31046/tl.v7i2.348

“Diktuon: Link Resolvers for Theological Libraries,” Stutzman, Karl, 6:1 (2013), 1-3. https://doi.org/10.31046/ tl.v6i1.257

“Diktuon: Mobile Devices and Libraries,” Keck, Andrew J., 5:1 (2012), 1-3. https://doi.org/10.31046/tl.v5i1.221

"An Evaluation of the Accessibility of E-resources from Theological Library Websites," Ganski, Kate L, 1:1 (2008), 38-45. https://doi.org/10.31046/tl.v1i1.14

\section{Theological education}

“Theological Libraries and 'The Next Christendom': Connecting North American Theological Education to Uses of the Book in the Global South,” Weaver, John B., 1:2 (2008), 38-48. https://doi.org/10.31046/tl.v1i2.45

“Latinos' Informational Needs in Attaining Accredited Theological Education,” Saxton, Filomena, 7:2 (2014), 20-25. https://doi.org/10.31046/tl.v7i2.342

“Student Theological Research as an Invitation,” Badke, William, 5:1 (2012), 30-42. https://doi.org/10.31046/ tl.v5i1.200

Theological librarians

“Librarianship as a Spiritual Practice,” Wigner, Dann, 10:1 (2017), 2-4. https://doi.org/10.31046/tl.v10i1.455

“Special Forum: Best Professional Development Experiences, Spring 2014,” Pakala, James C., Butler, Rebecca A., Darlack, James Marion, Day, Donald E., Kroll, Anna Lois, Amodeo, Anthony, Engelson, Leslie A. and Stewart, David R., 7:2 (2014), 26-30. https://doi.org/10.31046/tl.v7i2.344

"Theological Librarian vs. Machine: Taking on the Amazon Alexa Show (with Some Reflections on the Future of the Profession)," Sheppard, Beth M., 10:1 (2017), 8-23. https://doi.org/10.31046/tl.v10i1.475

“Theological Librarianship: An Unapologetic Apology,” McMahon, Melody Layton, 3:1 (2010), 7-14. https:// doi.org/10.31046/tl.v3i1.131

“Christian Librarians and the Ethics of the Library Bill of Rights," Kaihoi, Scott, 8:1 (2015), 42-60. https://doi. org/10.31046/tl.v8i1.353

“Expertise and Service: A Call to Action,” Butler, Rebecca, 8:1 (2015), 30-41. https://doi.org/10.31046/tl.v8i1.352

“The Theological Librarian’s Role in Fundraising,” Kemmis, Barbara, 2:1 (2009), 57-66. https://doi. org/10.31046/tl.v2i1.77

Theological libraries

“Incorporating Concepts of Hospitality into Theological Library Assessment,” Gundry, Jenifer, 8:1 (2015), 10-15. https://doi.org/10.31046/tl.v8i1.366

“The Future of the Small Theological Library,” Stephens, Myka Kennedy, 9:1 (2016), 28-32. https://doi. org/10.31046/tl.v9i1.411

“The Church Club of New York Library,” Rider, Jacqueline H., 6:2 (2013), 29-33. https://doi.org/10.31046/ tl.v6i2.296

“There is Nothing New Under the Sun? 'New Librarianship' and the Theological Library,” Osinski, Keegan, 8:1 (2015), 20-23. https://doi.org/10.31046/tl.v8i1.370

“Introduction: The Reshaping of Libraries,” Stewart, David R. and Crown, Ronald W., 5:1 (2012), 8. https://doi. org/10.31046/tl.v5i1.220 
“An Invisible Wall: The Relationship Between Congregational and Seminary Libraries in the United States," Eliceiri, Rebecca Klemme, 7:1 (2014), 28-29. https://doi.org/10.31046/tl.v7i1.324

"Running with Perseverance: The Theological Library's Challenge of Keeping Pace With Changing Students," Falciani-White, Nancy K., 1:2 (2008), 16-27. https://doi.org/10.31046/tl.v1i2.61

“Encouraging a Positive Outlook: The Benefits of Appreciative Inquiry in a Theological Library,” Miller, Rebecca Louise, Denneque, Seblewongel A and Cunningham, Paige Comstock, 7:1 (2014), 47-55. https:// doi.org/10.31046/tl.v7i1.312

“From the Ground Up: Starting a Theological Library from Scratch,” Truman, Gerald, 3:1 (2010), 23-26. https://doi.org/10.31046/tl.v3i1.133

"Uganda Christian University: A Center of Excellence in the Heart of Africa-An Overview of the UCU Library," Kiyaga, John, 4:1 (2011), 16-21. https://doi.org/10.31046/tl.v4i1.193

“The Library of the Universidad Bíblica Latinoamericana: 75th Anniversary in the Midst of Changes," Guzman, Alvaro Perez, 4:1 (2011), 8-15. https://doi.org/10.31046/tl.v4i1.195

“Telling the Library’s Story: A Personal Reflection,” Stuehrenberg, Paul, 5:2 (2012), 39-42. https://doi. org/10.31046/tl.v5i2.235

“Diktuon: Digital Repositories and Theological Libraries,” Keck, Andrew J., 1:1 (2008), 6-7. https://doi. org/10.31046/tl.v1i1.17

“Theological Libraries and Scholarly Publishing in Religion and Theology,” Keck, Andrew J., 11:2 (2018), 27-37. https://doi.org/10.31046/tl.v11i2.518

\section{Theology, Doctrinal}

“The Literature of Ecclesiology: A Ten Year Retrospective,” Guyette, Fred, 4:1 (2011), 75-90. https://doi. org/10.31046/tl.v4i1.146

“Pope Francis’ Strong Thought,” Lemna, Keith Edward, 7:2 (2014), 45-53. https://doi.org/10.31046/tl.v7i2.343

Theology, Practical

“Six Segments on Military Ministry,” Knapp, Kathryn, 3:1 (2010), 27-30. https://doi.org/10.31046/tl.v3i1.134

“Homiletics: A Bibliographic Essay,” Stern, Richard C., 6:1 (2013), 69-77. https://doi.org/10.31046/tl.v6i1.262

“Using Technology for Ministry: Trends, Principles and Applications,” Vergel, Alfredo, 3:2 (2010), 16-21. https://doi.org/10.31046/tl.v3i2.128

Universal design

“Libraries and Universal Design,” Spina, Carli, 10:1 (2017), 5-7. https://doi.org/10.31046/tl.v10i1.464 